Universidade de São Paulo

Faculdade de Filosofia, Letras e Ciências Humanas

Departamento de Ciência Política

\title{
Justiça e Gênero sob uma Perspectiva Cosmopolita
}

San Romanelli Assumpção

São Paulo 


\section{Justiça e Gênero sob uma Perspectiva Cosmopolita}

Tese apresentada como requisito parcial à obtenção do grau de Doutor em Ciência Política pelo Programa de Pós-Graduação em Ciência Política da Universidade de São Paulo.

Área de concentração: teoria política

Orientador: Prof. Dr. Álvaro de Vita

São Paulo

2012 
Autorizo a reprodução e divulgação total ou parcial deste trabalho, por qualquer meio convencional ou eletrônico, para fins de estudo e pesquisa, desde que citada a fonte.

Catalogação na Publicação

Serviço de Biblioteca e Documentação

Faculdade de Filosofia, Letras e Ciências Humanas da Universidade de São Paulo

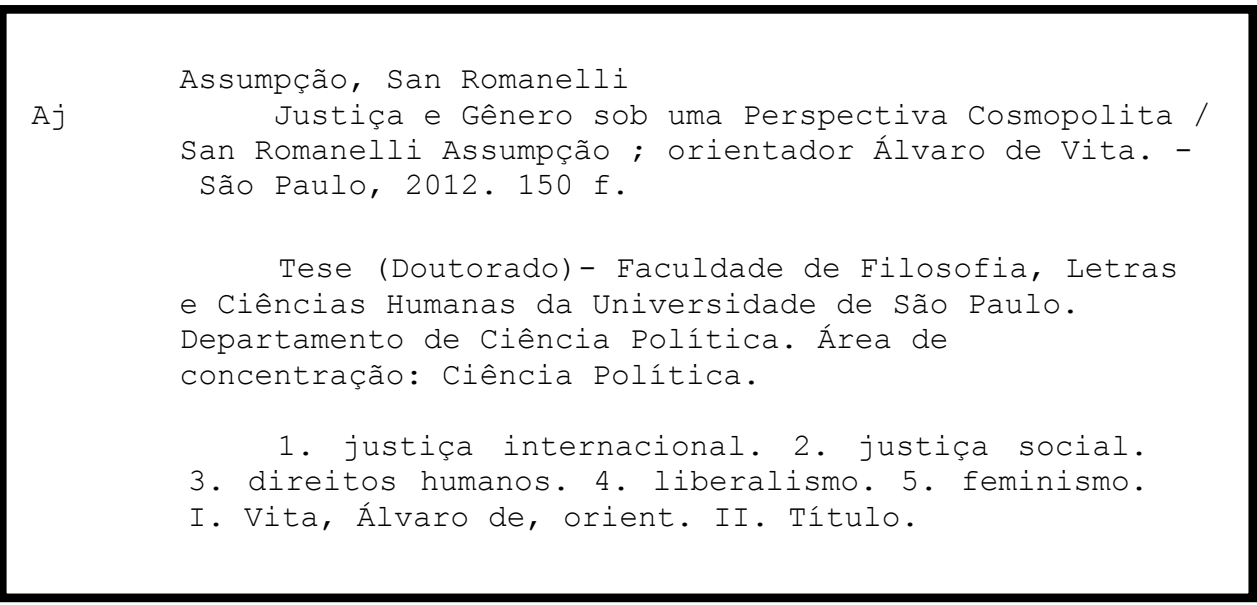




\section{FOLHA DE APROVAÇÃO}

San Romanelli Assumpção

Justiça e Gênero sob uma Perspectiva Cosmopolita

Tese apresentada ao Departamento de Ciência Política da Universidade de São Paulo para obtenção de título de doutor.

Área de concentração: Teoria Política

Aprovado em

Banca examinadora

Prof. Dr.

Instituição Assinatura

Prof. Dr.

Instituição Assinatura

Prof. Dr.

Instituição Assinatura

Prof. Dr.

Instituição Assinatura 
A Maria da Penha, Fadime Sahindal, Amina Lawal, Malala Yousafzai

e a todas 
"Sempre que há uma fronteira, há dois tipos de criaturas caminhando sobre a terra de Alá: os poderosos, de um lado, e, do outro, os sem poder." Perguntei a Mina como eu poderia saber de que lado me situava. Sua resposta foi rápida: "se você não conseguir sair, está do lado dos sem poder."

Dreams of Trespass. Tales of a harem girlhood.

Fatima Mernissi ${ }^{1}$.

Women have to often been treated as the supporters of the ends of others, rather than as ends in their own right. Women and Human Development. A capabilities approach. Martha Nussbaum².

My own fundamental concern is neither the basic structure of society, in any sense, nor people's individual choices, but the pattern of benefits and burdens in society: that is neither a structure in which choice occurs nor a set of choices, but the upshot of structure and choices alike.

Gerald Allan Cohen ${ }^{3}$

If the so-called private sphere is alleged to be a space exempt from justice, then there is no such thing. The Idea of Public Reason Revisited. John Rawls ${ }^{4}$

\footnotetext{
${ }^{1}$ Tradução utilizada: MERNISSI, Fatima. Sonhos de Transgressão. Minha vida de menina num harém. Trad. Carlos Sussekind. São Paulo, Cia. Das Letras, 1996.

${ }^{2}$ NUSSBAUM, Martha. Women and Human Development. A capabilities approach. Cambridge, Cambridge University Press, 2001.

${ }^{3}$ COHEN, G. A. If You're an Egalitarian, How Come You're So Rich? Cambridge-Mass.: Harvard University Press, 2001.

${ }^{4}$ RAWLS, John. "The Idea of Public Reason Revisited." In RAWLS, John. Political Liberalism. Expanded edition. Nova York, Columbia University Press, 2005.
} 


\section{Agradecimentos}

A Álvaro de Vita por muitas razões. Por me orientar generosamente desde 2003, por ser um professor e intelectual incansável, por me proporcionar incentivos, liberdade, confiança, segurança, respaldo e apoio intelectual numa conversa interminável. Sempre pela liberdade e cuidado para seguir quaisquer caminhos e perguntas. Por suas perguntas e perspectivas sempre afiadas. Por sua crença sólida no liberalismo igualitário. Por ter aberto caminhos para a teoria política normativa no Brasil sem os quais a minha tese e agenda de pesquisa seriam muito mais árduas.

A Andrei Koerner por ter sido orientador de minha primeira iniciação científica e ter me iniciado na teoria política normativa, na filosofia política, na leitura estrutural, por ter respeitado e incentivado todos os meus interesses e curiosidades intelectuais, por me indicado pela primeira vez a leitura da tese do Álvaro, por ter me aberto muitas portas e sempre discutir comigo minhas dúvidas e projetos.

A Cícero Araújo pelos trabalhos conjuntos, pelas portas abertas, pelas conversas, pela generosidade e abertura intelectual, por seu pensamento agudo, constante e inquieto, pelo ecletismo intelectual que me falta, por seus comentários e críticas valiosos em minha qualificação.

A Adrian Gurza Lavalle pelas vezes em que leu e discutiu meus textos e ideias, pela generosidade, abertura e incentivo intelectuais desde quando a minha tese ainda era um projeto tateando cegamente, pelos insights com que me presenteou no meio do caminho, pelo pensamento instigante, por seus comentários e críticas valiosos em minha qualificação.

A Matthew Taylor pela agradável surpresa de ter percebido, compreendido e apoiado intelectualmente partes "secretas" da minha pesquisa durante os Seminários de Pesquisa em 2009 e depois. Seu olhar e interesse de cientista político foram salutares para eu entender mais claramente meus interesses teóricos. 
A Wagner Pralon Mancuso pelas agradáveis sextas de 2009, discutindo teoria da democracia, teoria da justiça e sua relação com o universo das políticas públicas. Foi ótimo trabalhar como sua monitora.

À "Liga da Justiça” pelas leituras e discussões intermináveis e pela amizade. Minha tese deve muito à companhia intelectual de vocês, Lucas Petroni, Renato Francisquini, Raissa Ventura, Marcos Silveira, André Silva, Júlio Casarin, Flávio Reis. Agradecimentos especiais ao Lucas pelos insights, pelo espírito livre e pela anarquia intelectual conjunta, ao Renato Francisquini, meu co-autor de todas as horas, cuja amizade intelectual e incentivos foram fundamentais para todos os trabalhos que apresentei em 2011 e 2012.

À Representação Discente de 2011, pela vida intelectual, pela política discente e pela amizade, em especial à André Kaysel, Camila Rocha, Marcos Silveira e Roberta Soromenho. Ao RD da transição e editor da Leviathan Fabrício Vasselai. Ao Rogério Arantes, coordenador da Pós incansável e acessível sempre que nós RDs e alunos precisamos, um "soldado do DCP” como diz.

À Secretaria do DCP, em especial à querida e sempre competente Rai.

Ao CNPq, cuja bolsa tornou possível minha dedicação integral ao doutorado.

Aos amigos infinitamente queridos e companheiros Ana Cristina Joaquim, Adele Vrana, André Fabretti, Cláudia Marconi, Francesca Cricelli, Glenda Mezarobba, Josué Nóbrega, Juliana Inoue, Leandro Varison, Lucas Kiler, Marcelo Daniliauskas, Márcia Geronymo, Osmany Porto, Priscila Manzano, Rafael Gomes, Rodrigo Moura, Sérgio Simoni Jr, Silvana Roxo, Solenne Derigond, Thiago Nascimento, Tiago Borges, Uvanderson Silva e Waldir Hernandez, "pois na companhia de amigos - 'dois que andam juntos' - os homens são mais capazes tanto de agir como de pensar" (Aristóteles, Ética a Nicômaco).

A todos os amigos acima mencionados, há mais coisas a dizer do que caberia dizer aqui, direi pessoalmente.

A meus pais, Rosely e Fabio. Aos meus irmãos Flora, Tauana, Rafael e Clara. À tia Filhinha, à vó Zezé e aos tios Antônio Carlos e Luiz. Nada seria possível sem eles. 


\section{ASSUMPÇÃO, San Romanelli. Justiça e Gênero sob uma Perspectiva Cosmopolita.}

2012. Tese (doutorado). Departamento de Ciência Política da Universidade de São Paulo.

\section{RESUMO}

Esta tese investiga as possibilidades de uma proposta normativa feminista e cosmopolita para lidar com o problema das desigualdades de gênero e das violações das liberdades básicas das mulheres dentro da perspectiva liberal igualitária. Tendo como ponto de partida o axioma da igualdade moral humana e buscando alcançar um projeto de internacionalismo feminista liberal alternativo ao de Martha Nussbaum em Women and Human Development - The capabilities approach.

Para tanto, esta pesquisa discute o modo como as relações de gênero e coerções de gênero devem estar sob o escopo da justiça e busca construir uma interpretação da noção rawlsiana de "estrutura básica" como "objeto da justiça" que seja simultaneamente adequada do ponto de vista feminista e cosmopolita, a fim de que, em nome do próprio axioma da igualdade moral fundamental, seja possível dar conta da articulação entre os diversos horizontes da justiça: justiça local, justiça social e justiça cosmopolita.

E argumenta que esta articulação, dentro de uma concepção de "justiça institucional" compatível com a tolerância e justiça liberais, exige um equalisandum cosmopolita nos moldes dos bem primários rawlsianos como um modo moralmente defensável de se criar uma esfera de inviolabilidade individual que proteja as mulheres de violações advindas das desigualdades de gênero e lhes possibilite direito de saída, sem com isso ignorar a legitimidade do "pluralismo moral razoável".

Assim, defende-se que apenas uma lista de "bens primários" cosmopolita articula devidamente as possibilidades de saída nos planos local, social e cosmopolita, na constituição de um ideal de direito de saída pleno para as mulheres que seja conforme o ideal de tolerância liberal e com um "liberalismo político", tendo como 
"objeto da justiça" uma "estrutura básica" que inclui as coerções de gênero e cujo "meio para a justiça" é institucional. 


\title{
ASSUMPÇÃO, San Romanelli. A Cosmopolitan Approach to Gender and Justive.
} 2012. Tese (doutorado). Departamento de Ciência Política da Universidade de São Paulo.

\begin{abstract}
The thesis explores a normative proposal of solving some of the well-known gender's problems of inequality and infringement of woman's basic liberties from a feminist and cosmopolitan point of view. It assumes the axiom of human moral equality as its normative grounds although it attempts to achieve a feminist liberal approach quite different from Martha Nussbaum's Woman and Human Development - The Capabilities Approach.
\end{abstract}

To that end the research tries to conceive how gender tensions could be entailed by a theory of justice. Notwithstand the crucial distinctions between local, social and cosmopolitan justice, the work proposes a reinterpretation of the Rawlsian concept of "basic structure", as the main subject of justice, in which both feminism and cosmopolitanism aims can be fit into the axiom of moral human equality.

One of thesis' main objectives is to sustain the requirements of a cosmopolitan equalisandum as a feasible and morally relevant way to set up inviolable areas of individuality concerning protection against gender violence.

A rank of cosmopolitan "primary goods" also promotes the effectiveness of a series of exit rights: from the local context to the global one. It aims an ideal of full exit right to women that is entirely compatible with the liberal ideal of toleration. 


\section{SUMÁRIO}

1. Introdução ao problema normativo da desigualdade de gênero de um ponto de vista cosmopolita

2. A desigualdade de gênero é uma questão de justiça? A desigualdade de gênero é objeto do cosmopolitismo moral?

3. Gênero e o escopo da justiça liberal: o problema feminista e liberal igualitário da dicotomia entre público e privado

4. Primeira aproximação entre gênero e estrutura básica como objeto da justiça

5. Gênero e os âmbitos da justiça: pessoal, local, social e cosmopolita

6. Estrutura básica, coerção e gênero como objeto da justiça: o monismo moral em uma perspectiva feminista e cosmopolita

7. Sobre a relação entre gênero, família, religião, cultura e estrutura básica

7.1. Instituições, informais práticas sociais e estrutura básica

7.1.1. O argumento de Gerald Cohen

7.1.2. Instituições, publicidade e estrutura básica

7.1.3. Estrutura básica, formação de necessidades e justiça de fundo

7.1.4. Publicidade, cultura e instituições informais

8. A proposta cosmopolita de Nussbaum para as mulheres

9. A objeção neo-hegeliana e o problema das métricas cosmopolitas

10. Aproximações preliminares a um equalisandum de gênero cosmopolita

10. 1. A resposta recursista e rawlsiana de Pogge ao enfoque das capacidades

10.2. Bens primários cosmopolitas e direito de saída pleno 
1.

Introdução ao problema normativo da desigualdade de gênero de um ponto de vista cosmopolita

A desigualdade de gênero é um fenômeno mundialmente observado, não há país no qual a construção social do gênero e das relações de gênero não resulte em diferenças no acesso de homens e mulheres a direitos e liberdades civis, políticos, socioeconômicos e culturais. Diferenças estas que vão de desigualdades e restrições de liberdade comumente consideradas menos agressivas - como diferenças no acesso à educação escolar por meninos e meninas - a violações graves como a violência doméstica e o femicídio ${ }^{5}$. Sendo que as desigualdades de gênero usualmente consideradas menos agressivas, como as diferenças de salário e a divisão sexual do trabalho doméstico, impedem muitas mulheres do mundo de sair de situações de opressão que resultam em experiências trágicas, refletidas no alto número de violências e mortes causadas por construções sociais e culturais dos papéis de gênero, nas quais as mulheres também são sujeitos ativos.

Estudos da Anistia Internacional ${ }^{6}$ e da Organização Mundial de Saúde ${ }^{7}$ mostram que, em todo o mundo, mulheres sofrem cotidianamente violência física e sexual e agressões não-físicas orientadas por questões de gênero e os agressores são seus

\footnotetext{
${ }^{5}$ Feminicídio ou femicídio são termos para designar os assassinatos de mulheres ocorridos de modo que a morte possa ser associada a sua condição de gênero e ao sexismo. Atribui-se o surgimento do termo a Diana Russell, que o utilizou durante o "Tribunal Internacional de Crimes contra Mulheres" em Bruxelas em 1976. Em livro posterior, Russel e Caputti afirmam que "Femicide is on the extreme end of continuum of anti-female terror that includes a wide variety of verbal and physical abuse, such as rape, torture, sexual slavery (particularly in prostitution), incestuous and extra familial child sexual abuse; physical and emotional battery, sexual harassment (on the phone, in the street, on the office, and in the classroom), genital mutilation (clitoridectomies, excision, infibulations), unnecessary gynecological operations, forced heterosexuality, forced sterilization, forced motherhood (by criminalizing contraception and abortion), psychosurgery, denial of food to women in some cultures, cosmetic surgery, and other mutilations in the name of beautification. Wherever this forms of terrorism result in death, they become femicides" (Russel and Caputti, 1992, p. 2).

${ }^{6}$ AMNESTY INTERNATIONAL. Women, Violence and Health. Londres, Amnesty International, 2005.

${ }^{7}$ WHO. WHO Multi-country Study on Women's Health and Domestic Violence against Women. Geneve, WHO, 2005.

WHO. World Report on Violence and Health. Geneve, WHO, 2002.
} 
parceiros, suas famílias, vizinhos e desconhecidos. Estas agressões, das menores às mais graves, não causam apenas sofrimento físico ou emocional imediato, possuindo profundo impacto sobre as mais diversas dimensões da vida das mulheres e suas crianças ao longo de toda a sua existência, afetando sua saúde de um modo global, seu bem-estar psicológico, sua inserção social e econômica, a segurança de suas famílias e de suas comunidades.

Este problema de desigualdade e violação de liberdades é construído e perpetuado social e culturalmente e faz parte da própria construção do gênero como a “organização social da relação entre os sexos”, segundo a definição de Joan $\operatorname{Scott}^{8}$, ou, mais especificamente, como a "institucionalização da diferença sexual", no conceito de Susan Okin 9 .

Como aponta Amartya Sen,

The tolerance of gender inequality is closely related to notions of legitimacy and correctness. In family behavior, inequalities between women and men (and between girls and boys), are often accepted as 'natural' or 'appropriate' (even though they are typically not explicitly discussed). Sometimes, the operational decisions relating to these inequalities (e. g. providing more health care or nutritional attention to boys vis-à-vis girls) are undertaken and executed through the agency of women themselves. The perceived justness of such inequalities and the absence of any contrary sense of deep injustice play a major part in the operation and survival of these arrangements. This is not the only field in which the survival of extraordinary inequality is based on making 'allies' out of those who have most to lose from such arrangements ${ }^{10}$.

Este caráter social e cultural do gênero e suas desigualdades é emaranhado por regras e práticas expressas em leis e em políticas estatais que desfavorecem as mulheres. Indo desde legislações trabalhistas em que as mulheres se saem desfavorecidas pela gravidez e pela divisão sexual do trabalho doméstico - que as torna mais vulneráveis economicamente e menos aptas a sair de situações familiares opressivas - à atuação da polícia e do Judiciário, que desfavorecem as mulheres ao se orientarem por concepções

\footnotetext{
8 Joan Scott. "Gender: A useful category of historical analysis". The American Historical Review, Vol. 91, No. 5, 1986, pp. 1053-1075.

${ }^{9}$ Okin, Susan. Justice, Gender, and the Family. Nova York, Basic Books, 1989, p. 6.

${ }^{10}$ SEN, Amartya. Gender Inequality and Theories of Justice. In NUSSBAUM, Martha \& Jonathan Glover (eds.). Women, Culture and Development. A study of human capabilities. Oxford, Clarendon Press, 1995, pp. 259-273, p. 260.
} 
sociais do dever ser do comportamento feminino e da honra masculina. Há países em que isso se expressa explicitamente na própria lei, que restringe o direito das mulheres de ir e vir, de expressão e à vida profissional - que pode depender da aprovação de maridos, irmãos e pais - ou que atenua as penas de familiares homens que agridem e até mesmo matam mulheres por questões de honra.

Este entrelaçamento de construções culturais e sociais com práticas e legislações estatais torna o problema de gênero, simultaneamente, uma questão de discriminação social e de injustiça política e institucional. Discriminação social, porque ubiquamente praticada nas interações entre todas as pessoas morais ${ }^{11}$ socialmente concebíveis, sejam estas atores individuais ou coletivos, para além do Estado e das instituições formais. Injustiça política e institucional, porque impressa nas instituições e arranjos estatais. Esta concomitância é válida para a realidade da construção da desigualdade de gênero em todos os países e faz parte da força descritiva do slogan feminista "o pessoal é político".

Outro entrelaçamento importante ocorre entre as violações à integridade física e psicológica das mulheres e as possibilidades socioeconômicas e culturais das mulheres alterarem situações de opressão de gênero ou saírem delas (tanto no âmbito familiar quanto no profissional). Necessidades socioeconômicas das mulheres e seus filhos fazem com que, frequentemente, mulheres se submetam a violações e adversidades. A saída feminina de uma situação de opressão de gênero é difícil em realidades de relativa facilidade de sobrevivência econômica, devido a inúmeros fatores de ordem emocional e cultural, e é ainda mais difícil quando exercer a liberdade de saída inclui profunda pauperização para as mulheres e seus filhos ou até mesmo a separação de mães e filhos - pensemos no que podem significar a separação e o divórcio para uma mulher sueca em comparação com uma indiana, por exemplo.

A gravidade da dificuldade do direito de saída feminino ${ }^{12}$ fica patente no fato de que, segundo a Organização Mundial de Saúde, em todo o mundo, o fator que mais

\footnotetext{
${ }^{11}$ Utilizo aqui o termo "pessoas morais" do modo como Georg Cavallar o utiliza a partir de Kant, como equivalente a "pessoas jurídicas" e "sujeitos de direitos", podendo ser indivíduos, associações, comunidades, empresas, igrejas, Estados etc. Vide CAVALLAR, Georg. "A sistemática da parte jusfilosófica do projeto kantiano À Paz Perpétua". In Rohden, Valério (org.). Kant e a instituição da Paz. Trad. Peter Naumann. Porto Alegre, ed. universidade/UFRGS, Goethe-Intitut/ICBA, 1997, pp. 78-95.

${ }^{12}$ Os conceitos de saída, voz e lealdade são retirados de Hirschman. A voz - entendida como possibilidade de participação na determinação de uma situação, relação ou organização - e a saída -
} 
aumenta a possibilidade de uma mulher sofrer violência física e sexual é viver com um parceiro homem ${ }^{13}$. Sendo que, do total de mulheres assassinadas, de 40 a $70 \%$ variando conforme o país - são mortas por homens com quem viviam na época do assassinato ou viveram em uma época anterior ${ }^{14}$. Um relatório preparado pela Anistia Internacional cita um artigo segundo o qual,

For European women aged 16-44, violence in the home is the primary cause of injury and death, more lethal than road accidents and cancer. Between $25 \%$ and $50 \%$ of women are victims of this violence. In Portugal $52.8 \%$ of women say that they have been violently treated by their husbands and partners. In Germany almost 300 women a year or three women every four days - are killed by men with whom they used to live. In Britain one woman dies in similar circumstances every three days. In Spain it is one every four days. In France six women die this way every month: $33 \%$ of them are knifed, $33 \%$ shot, $20 \%$ strangled and $10 \%$ beaten. $^{15}$

O mesmo relatório cita que, na África do Sul, uma mulher é assassinada por um parceiro íntimo a cada seis horas, numa média de 28 mortes por semana; e $50 \%$ das mulheres sul-africanas assassinadas são mortas por homens com quem tiveram relação íntima em algum momento da vida ${ }^{16}$. Este relatório também afirma que, segundo dados da Human Rights Watch, na Jordânia, pelo menos 17 mulheres foram mortas em assassinatos de honra ${ }^{17}$ em 2003, 22 em 2002 e 19 em $2001^{18}$. E o Estado indiano,

compreendida como a possibilidade de se retirar de uma situação, relação ou organização - femininas em contextos de opressão de gênero são difíceis em realidades de relativa facilidade de sobrevivência econômica, devido a inúmeros motivos de ordem emocional e cultural. E são ainda mais difíceis quando exercer a liberdade de saída - através do divórcio, por exemplo - implica profunda pauperização, o que afeta não apenas as mulheres, mas também seus filhos. $O$ alto preço da saída feminina pode enfraquecer a voz das mulheres. O enfraquecimento de sua voz pode tornar a saída uma necessidade de segurança mais premente. E a combinação perversa do empobrecimento dos mecanismos de voz e saída podem transformar a lealdade - entendida como permanência em uma situação, relação ou organização - em nada mais que a falência das primeiras. O conceito de saída é central para este trabalho por diversas razões, entre elas, porque é central ao liberalismo e sua concepção de tolerância, porque é central para a proposta normativa de Nussbaum, porque é a base das teorias minimalistas dos direitos humanos e devido à relação entre estes conceitos e as exigências da tolerância liberal cosmopolita. (Os conceitos de saída, voz e lealdade estão em HIRSCHMAN, Albert. Saída, Voz e Lealdade. Reações ao declínio de firmas, organizações e estados. São Paulo, Perspectiva, 1973.)

${ }^{13}$ WHO, 2002, p. 157.

${ }^{14}$ WHO, 2002, p. 93.

${ }^{15}$ Ramonet I. "Violence Begins at Home." Le Monde Diplomatique, [English edition] July 2004, citado por Anistia Internacional, 2005, p. 5.

${ }^{16}$ Mathews S, Arahams N, Martin LJ, Vetten L, van de Merwe L, Jewkes R. "Every Six Hours a Woman Is Killed by her Intimate Partner: a national study of female homicide in South Africa." MRC Policy Brief No. 5, junho de 2004. Citado por International Amnesty, 2005, p. 23.

${ }^{17}$ Assassinatos motivados por defesa da honra masculina (de maridos, pais, irmãos e demais homens da família) e da honra da família, entendida como honra relativa, principalmente, aos homens da família, à 
através de seu National Crime Records Bureau, reporta que, em 2010, houve ao menos 8391 casos de dowry death ou dowry murder, ou seja, a cada noventa minutos uma mulher foi assassinada pela família de seu marido, por esta considerar seu dote inferior ao desejável ${ }^{19}$.

Passando ao caso brasileiro, Rosana Heringer, Coordenadora do Programa de Direitos da Mulher da Action Aid no Brasil, afirma que, neste país, "a cada 16 segundos uma mulher é agredida por seu companheiro e $70 \%$ das mulheres assassinadas foram vítimas de seus próprios maridos" ${ }^{20}$. E segundo pesquisa do Instituo Zangari a partir de dados do Sistema Único de Saúde (SUS), quase 40\% dos assassinatos de mulheres no Brasil ocorre em suas $\operatorname{casas}^{21}$. Informações como estas mostram que a realidade brasileira da desigualdade e violência de gênero guarda semelhanças com a dos demais países.

Levantamentos feitos pela Anistia Internacional, Human Rights Watch, Organização Mundial de Saúde produziram dados sobre diversos outros países (Brasil, Peru, México, Turquia, Sérvia e Montenegro, Índia, Paquistão, Bangladesh, Tailândia, Etiópia, Namíbia, Tanzânia, Estados Unidos e Austrália) que apontam que a violência de gênero - emocional, física e sexual - ocorre predominantemente contra as mulheres e afeta profundamente suas vidas e a de seus filhos nos mais diversos aspectos - saúde física, bem-estar psicológico, inserção social e profissional, acesso a bens e oportunidades. Estes mesmos estudos relatam que muitas mulheres não estão satisfeitas com as violações de que são vítimas, ao mesmo tempo em que diversas práticas endossadas por estas mesmas mulheres e outras colaboram para a perpetuação deste quadro de desigualdades e violações baseadas no gênero, num quadro bastante intrincado de endossos e repúdios afirmados pelas próprias mulheres a respeito das desigualdades e violações de gênero.

religião e à tradição (vide WIKAN, Unni. Em Honra de Fadime. Assassinato e Humilhação. Trad. Beth Honorato. São Paulo, Editora UNIFESP, 2010).

${ }^{18}$ International Amnesty, 2005, p. 23.

${ }^{19}$ http://www.telegraph.co.uk/news/worldnews/asia/india/9108642/Indian-dowry-deaths-on-therise.html, acessado em setembro de 2012.

${ }^{20}$ http://www.actionaid.org.br/Portals/O/Releases/DireitoMulheres/Mulheres 2006.pdf

21 http://www.sangari.com/mapadaviolencia/\#mulheres e

http://www.sangari.com/mapadaviolencia/pdf2011/homicidio mulheres.pdf. 
Se olharmos para o plano doméstico das sociedades ditas ocidentais e ocidentalizadas, vemos muitas feministas, teóricas feministas e movimentos sociais afirmando o valor moral da igualdade de gênero e a urgência política de a implementarmos. Isso também é aceito por muitas pessoas que não se identificam como feministas e está impresso em diversas leis e políticas. Ainda que em menor proporção, também encontramos defesas de direitos das mulheres e de maior igualdade de gênero em sociedades não ocidentais, nas palavras de mulheres que se identificam como feministas, de mulheres que não se pensam desta maneira e mesmo de movimentos de mulheres. E mulheres sob condições limites de opressão - como aquelas condenadas à morte por adultério e as hospitalizadas por motivos de violência doméstica e sexual, por exemplo - quando indagadas por movimentos, instituições multilaterais e ONGs como a Anistia Internacional, a Human Rights Watch, os Médicos sem Fronteiras e o Comitê CEDAW também afirmam insatisfação com o que as colocou nestas situações. Ou seja, a existência mundial de mulheres, associações de mulheres e movimentos de mulheres reivindicando que esta desigualdade diminua e que o acesso a liberdades seja facilitado é fato, assim como a desigualdade de gênero. Mas, ao mesmo tempo, há mulheres, associações de mulheres e movimentos de mulheres reivindicando a permanência de valores e práticas sociais, culturais e religiosos que perpetuam a desigualdade de gênero e legitimam socialmente as diversas formas de sanções às mulheres que não se adequam plenamente ao que é socialmente esperado delas. Ou seja, a desigualdade de gênero existe nos mais diversos países e culturas, mas estes não nos fornecem nenhuma razão claramente pronunciada por mulheres para afirmarmos ou negarmos o valor normativo da igualdade de gênero e a extensão que esta deve abraçar ${ }^{22}$.

\footnotetext{
${ }^{22}$ Opiniões feministas e antifeministas existem em todo o globo e os feminismos estão longe de se restringir ao ocidente. Exemplos de formulações femininas e antifeministas sobre a vida das mulheres e as coerções a que estão expostas, bem como opiniões mais e menos igualitárias e liberais das mulheres sobre essa realidade podem ser verificadas em pronunciamentos de diversos movimentos e ONGs de mulheres de todo o mundo e em pronunciamentos de lideranças feministas como ativista e advogada iraniana Shirin Ebadi e de artistas como a jornalista, escritora e poetisa libanesa Joumana Haddad. Há muitos grupos feministas em todo o mundo, inclusive em continentes frequentemente citados por seu tradicionalismo e sexismo, como a Ásia e a África. Há movimentos africanos pró e contra a mutilação genital feminina e movimentos de mulheres islâmicas pró e contra o uso do véu, por exemplo. Martha Nussbaum cita muitas opiniões de mulheres indianas (por ela entrevistadas) que são críticas frente às violações a que estão sujeitas, assim como muitas opiniões tradicionalistas; isso pode ser verificado em todos os seus livros que lidam com a questão da mulher. Também podemos verificar estas opiniões em livros escritos por mulheres de todo o mundo. Em particular, lembro o livro de Fatima Mernissi (1966) citado entre as epígrafes e FERNEA, Elizabeth Warnock \& Basima Qattan Bezirgan (orgs.). Middle Eastern Muslim Women Speak. Austin, university of Texas Press, 1977.
} 
Como diz R. R. Palmer, "a igualdade requer um ato de escolha, pelo qual algumas diferenças são minimizadas ou ignoradas enquanto outras são maximizadas e postas a se desenvolver." ${ }^{23}$ É isto que precisamos encontrar e delinear normativamente. A igualdade não está dada e seu escopo precisa ser construído pelas teorias políticas e feministas e pelos atores políticos e sociais. E, como mostram os trabalhos de Joan Scott, "a igualdade no Ocidente tem geralmente se referido a direitos - direitos que eram considerados possessão universal dos indivíduos não obstante suas diferentes características sociais." 24 Precisamos refletir sobre a viabilidade normativa de defendermos este tipo de igualdade frente à questão de gênero nos planos domésticos das diversas sociedades e no âmbito global, ou seja, a viabilidade normativa de pensarmos uma justificação cosmopolita para a defesa da igualdade de gênero calcada em direitos.

Em suma, a desigualdade de gênero existe nos mais diversos países, empobrece mulheres e crianças mais do que homens e aumenta as possibilidades das mulheres serem violadas e assassinadas por seus parceiros e demais familiares, isto é fato. No entanto, como diz Sen, "an observation of inequality can yield a diagnosis of injustice only through some theory (or theories) of justice" ${ }^{25}$. Ou, como afirma Brian Barry, os fatos não nos dizem sobre a justiça ou injustiça das sociedades e seus Estados, para isso precisamos de teorias normativas da justiça ${ }^{26}$.

Assim, precisamos atentar para diversas questões seminais As diferenças de acesso a direitos e liberdades causadas por desigualdade de gênero e relações de poder entre os gêneros constituem um problema de moralidade política? São violação de direitos humanos ou injustiça? Como estas desigualdades podem ser acessadas pelas teorias normativas da justiça? As respostas dependem

(1) de acreditarmos ou não em uma igualdade humana fundamental, isto é, assumirmos ou não o axioma da igualdade moral humana ${ }^{27}$; do que entendemos ser a interpretação deste axioma ${ }^{28}$;

\footnotetext{
${ }^{23}$ PALMER, R. R. "Equality". In WIENER, Philip P. (org.). Dictionary of the History of Ideas. Nova York, Scribner, 1973-74, p. 139. Citado por SCOTT, Joan. "O Enigma da Igualdade". Estudos Feministas, Vol. 13, No. 1, jan-abril de 2005, pp. 11-30, p. 15.

${ }^{24}$ Scott, 2005, p. 16.

${ }^{25}$ Sen, 1995, p. 260.

${ }^{26}$ Brian Barry. Why Social Justice Matters. Malden-MA, Polity Press, 2008, p. 13.

${ }^{27}$ Este trabalho assume este postulado.
} 
(3)

da definição do cerne/locus dessa igualdade, que deve estar refletido no "padrão avaliatório" e "equalisandum" através do qual acessamos as ideias de qualidade de vida e justiça ${ }^{29}$; das consequências normativas deste entendimento da igualdade moral humana, isto é, se dela decorre uma reivindicação moral por direitos humanos, tolerância, legitimidade política, democracia ou justiça social $^{30}$;

de qual a nossa concepção a respeito do objeto da justiça a que devem se endereçar os princípios político-morais apropriados a nossa concepção de igualdade moral $^{31}$; e

de qual equalisandum melhor incide sobre este objeto da justiça, a fim melhor endereçarmos as reivindicações morais advindas de nossa concepção de igualdade moral humana e de suas exigências normativas, que, conforme dissemos, podem ser uma concepção de direitos humanos, tolerância, legitimidade política, democracia ou justiça social ${ }^{32}$.

Estas são diversas ordens de questões normativas distintas entre si, mas cuja solução é conjunta e indissociável, ainda que possa ser dividida para facilitar sua compreensão e análise. Acresce-se a isso o fato de que estas questões podem exigir respostas distintas conforme estejamos tratando de diferentes âmbitos da moralidade política, isto é, de justiça e tolerância como virtudes sociais ou como virtudes institucionais, da moralidade política estatal ou da moralidade política cosmopolita ou ainda da moralidade das condutas individuais, das éticas próprias aos âmbitos privados e públicos ${ }^{33}$. Considerando esta diversidade de áreas de reflexão normativa, esta tese

\footnotetext{
${ }^{28}$ Exposta na p. 8.

${ }^{29}$ Este paper devenderá "bens primários" como métrica de uma igualdade de gênero cosmopolita. A principal teoria de justiça internacional quanto a gênero presente no debate contemporâneo é a de Martha Nussbaum, que defende uma lista de capacidades funcionais humanas centrais válidas para todos os países. São exemplos de padrões avaliatórios, métricas e equalisanda os bens primários, direitos, renda e riqueza, recursos, bem-estar, felicidade, functionings e capacidades etc.

${ }^{30}$ Esta pesquisa defenderá uma concepção cosmopolita de "direito de saída pleno" para as mulheres.

${ }^{31}$ Esta pesquisa defenderá uma interpretação do conceito rawlsiano de estrutura básica da sociedade que se pretende mais adequada para acessar o problema da desigualdade de gênero e das violações de que as mulheres são vítimas em todo o mundo.

32 Defender-se-á, ao final desta pesquisa, uma lista de "bens primários" cosmopolita como equalisandum que melhor lida com o problema da desigualdade de gênero em âmbito cosmopolita.

${ }^{33}$ Utilizo o plural remetendo às reflexões de Susan Okin sobre as várias camadas do público e do privado.
} 
pretende discutir a existência de um problema de moralidade política cosmopolita relativo à desigualdade de gênero, sua importância e possíveis respostas teóriconormativas de um ponto de vista cosmopolita, na busca de um feminismo cosmopolita ou de um cosmopolitismo feminista. 


\section{2.}

\section{A desigualdade de gênero é uma questão de justiça? A desigualdade de gênero é objeto do cosmopolitismo moral?}

A primeira e mais óbvia pergunta normativa advinda do fato de que a desigualdade de gênero é uma realidade mundial que, em suas situações limites, atinge o extremo da violação da integridade física de mulheres e crianças é: isso é moralmente errado? Desigualdade de gênero é uma questão moral? Se sim, é um problema de moralidade política? É uma questão de justiça? Ou, nas palavras de Susan Okin, "quão justo é o gênero?"34

O feminismo liberal de um modo geral responderia que sim, a desigualdade e dominação de gênero são moralmente erradas - nos diversos planos da moral individual, religiosa, familiar, econômica, política etc. -, constituem um problema de moralidade política - relativa à virtude política individual, social e institucional-estatal e violam a democracia e a justiça enquanto campos normativos específicos. E, especificamente para Susan Okin, feminista e liberal, o gênero em si - definido como "institucionalização da diferença sexual" - é injusto, dentro de uma concepção de feminismo como

the belief that women should not be disadvantaged by their sex, that they should be recognized as having human dignity equal to that of men, and that they should have the opportunity to live as fulfilling and as freely chosen lives as men $\mathrm{can}^{35}$.

Apesar desta definição de feminismo ser apenas uma afirmação da igualdade moral entre mulheres e homens, ela traz muitas implicações teórico-normativas a respeito do que é ou não objeto de justiça e de moralidade política.

A negação ou afirmação da desigualdade de gênero como questão de justiça e objeto da justiça depende do que acreditamos ser o plano da igualdade e liberdade

\footnotetext{
${ }^{34}$ Em inglês, "how just is gender?" OKIN, Susan Moller. Justice, Gender, and the Family. Nova York, Basic Book, 1989, p. 8.

${ }^{35}$ Okin, Susan. "Is Multiculturalism Bad for Women?" In Cohen, Howard \& Nussbaum (orgs.). Is Multiculturalism Bad for Women? Susan Moller Okin with respondents. Princeton, Princeton University Press, 1999, pp. 7-24, p. 10.
} 
humanas, o que inclui (1) o que concebemos ser a universalidade ou paroquialidade do escopo destes dois ideais e (2) os tipos de relações entre pessoas morais a que estes ideais se dirigem.

A perspectiva do individualismo ético afirma que o valor e unidade última de preocupação moral são os indivíduos e que todas as pessoas são fins em si mesmos, não podendo ser instrumentalizadas em nome de outros fins ou de qualquer tipo de coletividade - religiosa, cultural, nacional, étnica, política etc. Esta perspectiva exige como ponto de partida o axioma da igualdade moral fundamental, que afirma que todos os seres humanos possuem igual direito e liberdade de escolher que concepção de boavida seguir.

Para os cosmopolitismos morais, este axioma é válido para pensarmos as liberdades e a igualdades de todas as pessoas, pertencentes a quaisquer associações e comunidades, independentemente de seus países de nascimento e decorrer da vida (o que inclui cidadãos e imigrantes); e isso faz com que, independentemente de seus vínculos e relações, haja um rol de liberdades e/ou bem-estar que deveriam existir nas vidas tanto de um somali ou de um boliviano, quanto de um sueco ou de um norteamericano, independentemente das histórias de seus países e das ações de seus Estados.

Ao olharmos para o fato de que as mulheres, comparadas aos homens, são especialmente vulneráveis em todos os países e possuem menor liberdade e qualidade de vida devido a desigualdades oriundas das construções de gênero, tomamos ou não isto como um problema de moralidade política e/ou de moralidade política cosmopolita de acordo com o modo como entendemos o dever ser das relações entre as pessoas morais e o âmbito da tolerância e da justiça.

O caráter social e cultural das construções de gênero faz desta categoria um locus da expressão dos particularismos culturais próprios do pluralismo moral, uma parte constitutiva fundamental da identidade e personalidade das pessoas e uma construção de poder que permeia as diversas esferas da vida social - política, econômica, social, cultural e religiosa. Ou seja, gênero é uma construção social indissociável da constituição de todas as pessoas em todas as suas dimensões individual, familiar, religiosa, comunitária, profissional etc. - não sendo externo aos bens sociais e culturais e nem às identidades pessoais, que, inescapavelmente, são social 
e culturalmente situadas e construídas. São todas as pessoas, em sua individualidade, que são unidade última de preocupação moral para o individualismo ético. E todas as pessoas são constituídas socialmente através de relações de poder como são as relações de gênero. Sendo assim, como a tolerância e a justiça institucionais calcadas no individualismo ético e no axioma da igualdade moral humana devem lidar com o gênero e com sua desigualdade e diferença ${ }^{36}$ ?

Para Rawls, (1) "cada pessoa possui uma inviolabilidade fundada na justiça" e que não pode ser desconsiderada em função de nenhum bem ou objetivo ${ }^{37}$, (2) que os princípios de justiça são "um modo de atribuir direitos e deveres nas instituições básicas da sociedade e definem a distribuição apropriada dos benefícios e dos encargos da cooperação social"38, (3) o "objeto da justiça" é a "estrutura básica da sociedade", formada pelas principais instituições políticas, econômicas e sociais que dão as possibilidades de vida disponíveis a cada posição social e (4) e as alternativas de vida disponíveis às pessoas não devem ser constrangidas por "arbitrariedades morais", entendidas como vantagens e desvantagens sociais que são fruto da distribuição natural de qualidades e de contingências sociais e não do merecimento individual, assim, algo é moralmente arbitrário que alguém consiga um maior acesso a vantagens sociais porque nasceu em uma determinada classe, etnia, gênero ou com determinadas características físicas ou talentos ${ }^{39}$. Rawlsianamente, é dentro deste arcabouço que as relações de gênero devem ser discutidas como parte ou não do escopo da justiça.

Em uma outra elaboração normativa, seguindo À Paz Perpétua ${ }^{40}$ de Kant, podemos afirmar que o "direito racional" mesmos e a possiblidade de que sejam livres através da regulação de todos os âmbitos em que, efetiva ou potencialmente, houver trocas de influências recíprocas entre pessoas morais que possam ameaçar as pessoas como fins em si mesmos ${ }^{42}$. Assim, na

\footnotetext{
${ }^{36}$ Uso os dois termos porque, para muitas feministas, "desigualdades de gênero" refletem relações de poder e são injustas, ao passo que "diferenças de gênero" refletem a pluralidade de formas de existência e concepções de bem e devem ser respeitadas. Neste trabalho, as desigualdades de gênero que importam para a normatividade política e institucional são aquelas que refletem relações de poder e resultam, efetiva ou potencialmente, em violações de liberdade básicas.

${ }^{37}$ Rawls, John. Uma Teoria da Justiça. São Paulo, Martins Fontes, 2008, p. 4.

${ }^{38}$ Rawsl, 2008, p. 5.

${ }^{39}$ Rawls, John. Uma Teoria da Justiça. Lisboa, Presença, 1993, pp. 35-36.

${ }^{40}$ KANT. À Paz Perpétua e outros Opúsculos. Trad. Artur Mourão. Lisboa, Edições 70, 1995.

${ }^{41} \mathrm{O}$ direito ideal para Kant.

${ }^{42}$ Kant, 1995, p. 127.
} 
formulação de Onora O'Neill, em nome da dignidade humana igual e universal, os princípios de justiça deve ser universais e endereçados a todos os membros de qualquer pluralidade de seres entre os quais haja interação efetiva e potencial ${ }^{43}$. Esta é uma outra abordagem teórico-normativa dentro da qual podemos nos perguntar sobre as relações de gênero como preocupação de justiça.

Há em comum entre ambas a noção de que são objeto de preocupação da moralidade política as relações entre pessoas morais que podem violar a dignidade humana e a igualdade moral. Através de ambas as abordagens é possível afirmar que relações de gênero são relações e trocas de influência entre pessoas morais - sejam estas indivíduos, grupos ou instituições - que violam efetiva ou potencialmente a igualdade fundamental entre mulheres e homens e que, de algum modo, a justiça deve ser endereçada a estas relações. Resta saber de que maneira colocar estas relações sob o escopo da justiça não viola o seguinte aspecto do axioma da igualdade moral humana: o de que todas as pessoas possuem igual liberdade e direito de seguir sua concepção de bem. Esta igual liberdade universal e individualista se relaciona diretamente com os particularismos culturais e comunitários, com o pluralismo moral e com a tolerância liberal, pontos sensíveis para qualquer internacionalismo feminista que pretenda dar liberdade para as mulheres sem desrespeitar a possibilidade de que as mulheres possam escolher genuinamente uma vida de modéstia feminina e de valores sexistas tradicionais. Como lidar política e institucionalmente com isso, dado que a justiça e o Direito são estatalmente implementados?

Um primeiro ponto a ser observado a respeito das diversas relações entre pessoas morais, é que gênero transcende o meramente institucional e estatal, gênero faz parte, igualmente, do público e do privado; e gênero perpassa igualmente instituições formais e informais, estatais e não-estatais: isso faz com que gênero seja simultaneamente uma questão de "justiça social" justiça interna a um país - de "justiça local" 45 - entendida preliminarmente como justiça

\footnotetext{
${ }^{43}$ O'NEILL, Onora. Bounds of Justice. Cambridge: Cambridge University Press, 2000, p. 158.

${ }^{44}$ Consideraremos "justiça social" de acordo com a concepção rawlsiana, que considera esta a "justiça da estrutura básica da sociedade", pensada para o plano internos às chamadas "sociedade liberais".

${ }^{45}$ Utilizamos aqui o termo "justiça local" conforme Rawls o utiliza em Justiça como Equidade. Uma reformulação (São Paulo, Martins Fontes, 2003). Rawls diferencia os princípios de justiça endereçados à estrutura básica (âmbito da "justiça social") daqueles que são endereçados "às associações, instituições e práticas sociais em geral". Citando-o: "Temos ao todo, de dentro para fora, três níveis de justiça: primeiro, a justiça local (os princípios que se aplicam diretamente a instituições e associações); segundo,
} 
interna a associações, comunidades, organizações e instituições menores do que um país - e, simultaneamente, uma questão de virtudes sociais - das relações interpessoais e entre grupos sociais - e virtudes institucionais - próprias das instituições estatais, das leis e das políticas públicas.

Um segundo ponto é que gênero é uma construção realizada, de diversas maneiras, em todas as sociedades: o que faz das desigualdades e diferenças de gênero, simultaneamente, questão de "justiça social" e de "justiça cosmopolita" preliminarmente como justiça que transcende as fronteiras estatais.

A junção destes dois pontos através do problema da desigualdade de gênero coloca em questão, simultaneamente, (1) o "horizonte de justificação moral" - se devemos mirar o local, o estatal, a sociedade inteira de um país ou o mundo - e (2) a interpretação adequada do objeto ao qual a justiça é endereçada - numa interpretação rawlsiana da justiça, seu "objeto primário" é a "estrutura básica da sociedade", que forma as condições e possibilidades de vida de todas as posições sociais. As desigualdades de gênero e violações de liberdade delas decorrentes são especialmente iluminadoras destes dois pontos, que serão norteadores de toda a reflexão desta tese e serão norteadores de nossas buscas de respostas para as questões a respeito das relações entre desigualdade de gênero e justiça.

a justiça doméstica (os princípios que se aplicam à estrutura básica da sociedade); e, por fim, a justiça global (os princípios de justiça que se aplicam ao direito internacional)" (Rawls, 2003, pp. 15-16). Rawls esclarece na nota 9 que o conceito de "justiça local" é tomado de Jon Elster (Rawls, 2003, p. 15).

${ }^{46}$ Entendemos "justiça cosmopolita" como a justiça global cuja unidade última de preocupação moral seja concebida como sendo os indivíduos e não quaisquer coletividades (nem mesmo os Estados). 


\section{Gênero e o escopo da justiça liberal: o problema feminista e liberal igualitário da dicotomia entre público e privado}

Como citado acima, para Joan Scott, gênero é a organização social da relação entre os $\operatorname{sexos}^{47}$. Esta definição é ampla o suficiente para ser endereçada às relações sociais entre homens e mulheres em todas as sociedades e épocas. Conforme apontam inúmeros autores, como a própria Joan Scott, Susan Okin e Pierre Bourdieu - para citar apenas autores amplamente influenciadores desta tese - não há sociedade ou época em que inexistam assimetrias de poder entre homens e mulheres e nos quais estas não sejam profundamente determinadoras das possibilidades de vida disponíveis para homens e mulheres, ainda que estas assimetrias tenham se constituído de modos diferentes em sociedades e épocas diversas. Usando a terminologia de Bourdieu, podemos afirmar que a "dominação masculina" 48 é universal. Ou, nos termos de Catherine MacKinnon, a "supremacia masculina"49 é universal. Nesta tese, isso significa simplesmente que as mulheres possuem acesso a menos direitos e liberdades em todos os países do mundo. Os exemplos sobre violações da liberdade e integridade das mulheres e as desigualdades que são parte do que constitui suas vidas - citadas na Introdução - são uma mostra do modo como deste universal factual.

Uma primeira resposta à pergunta sobre se gênero é uma questão de justiça é que, se a justiça, rawlsianamente, diz respeito à uma inviolabilidade individual igual que é devida a todos, desigualdades de gênero que geram desigualdade de acesso a direitos e liberdades efetivos são sim um problema de justiça.

Mas há uma dificuldade importante nesta resposta: gênero permeia todas as relações e instituições sociais, naquilo que MacKinnon caracteriza como a ubiquidade do gênero. Ou seja, gênero são relações de poder que se constroem pública e privadamente, transcendendo a dicotomia tradicional entre público e privado. Sendo assim, se gênero é uma questão de justiça, a justiça é um ideal que se aplica a todas as

\footnotetext{
${ }^{47}$ Scott, 1986.

${ }^{48}$ BOURDIEU, Pierre. A Dominação Masculina. Trad. Maria Helena Kühner. Rio de Janeiro, Bertrand Brasil, 2011, 10a. ed..

${ }^{49}$ MacKINNON, Catharine A. Feminism Unmodified. Discourses on Life and Law. Cambridge-Mass., Harvard University Press, 1987.
} 
relações sociais possíveis? A ubiquidade do gênero gera normativamente alguma forma de ubiquidade da justiça?

Conforme aponta Okin,

Distinções entre público e privado têm tido um papel central, especialmente na teoria liberal - o 'privado' sendo usado para referirse a uma esfera ou esferas da vida social nas quais a intrusão ou interferência em relação à liberdade requer justificativa especial, e o 'público' para referir-se a uma esfera ou esferas vistas como geralmente ou justificadamente mais acessíveis ${ }^{50}$.

Sendo o privado uma esfera na qual a interferência estatal deve ser evitada e requer justificação especial, como o privado se relaciona com a justiça?

Ainda conforme mostra Okin, este privado que exige justificação especial para sofrer interferência estatal refere-se a duas diferenciações, entre sociedade e Estado e entre a vida doméstica e a não-doméstica. Na primeira, o domínio socioeconômico intermediário ou sociedade civil pertence ao âmbito privado, na segunda, ao público ${ }^{51}$. E estas duas diferenciações ainda podem se desdobrar internamente. Susan Okin remete-se à analogia proposta por W. L. Weinstein ${ }^{52}$ entre privacidade/publicidade e as camadas de uma cebola, pois o que é privado em relação a uma esfera da vida pode ser público em relação à outra, o que implica que não se trata apenas de uma significação dual e dicotômica ${ }^{53}$. Assim, por exemplo, empresas e o mercado são privados se comparados ao Estado, mas são públicos se comparados à família. Noutro exemplo, Igrejas são privadas se comparadas ao Estado, mas as famílias são ainda mais privadas do que as Igrejas.

O liberalismo rawlsiano e igualitário possui como uma de suas características normativas centrais justamente considerar que não são apenas as estruturas e instituições estatais que são objeto de preocupações de justiça, mas também estruturas e instituições econômicas e sociais, que também são fundamentais na determinação das vidas das pessoas. Ainda que Rawls possa ser ambíguo sobre o modo como a família é

\footnotetext{
${ }^{50}$ OKIN, Susan. "Gênero, o público e o privado." Estudos Feministas 16(2), maio-agosto de 2008, pp. 305-332, p. 306.

${ }^{51}$ Okin, 2008, pp. 306-307.

${ }^{52}$ Okin cita WEINSTEIN, W. L. "The Private and the Free: A Conceptual Inquiry." In: PENNOCK, J. Roland, and CHAPMAN, John W. (eds.). Privacy: Nomos XIII. New York: Atherton, 1971. p. 32-35.

${ }^{53}$ Okin, 2008, p. 307.
} 
ou não objeto de justiça, o capitalismo é, inegavelmente, objeto dela. Assim, já em Rawls vemos que a dicotomia entre público e privado não delimita de modo estanque o que é ou não preocupação de justiça. Nas palavras de Thomas Nagel,

\begin{abstract}
Rawls's theory is the latest stage in a long evolution in the content of liberalism that starts from a narrower notion, exemplified by Locke, which focused on personal freedom and political equality. The evolution has been due above all to recognition of the importance of social and economic structures, equally with political and legal institutions, in shaping people's lives and a gradual acceptance of social responsibility for their effects. When the same moral attention was turned on these as had earlier focused on strictly political institutions and uses of political power, the result was an expansion of the liberal social ideal and a broadened conception of justice. Indeed, the use of the terms "just" and "unjust" to characterize not only individual actions and laws but entire societies and social or economic systems is a relatively recent manifestation of this change of outlook. Rawls's liberalism is the fullest realization we have so far of this conception of the justice of a society taken as a whole whereby all institutions that form part of the basic structure of society have to be assessed by a common standard ${ }^{54}$.
\end{abstract}

Assim, a partir de Rawls, o liberalismo passa a possuir uma vertente que defende normativamente que a primeira diferenciação mencionada por Susan Okin - entre sociedade e Estado - não delimita um âmbito acima da justiça e sobre o qual o Estado não deve interferir. A igualdade humana fundamental como premissa ética exige que o liberalismo rawlsiano, em nome da equidade de oportunidades normativamente devida a todos, não pense as estruturas e instituições econômicas e sociais como completamente fora do escopo da justiça, mesmo quando não se reduzem ao estatal e legal.

Essa mesma premissa incide sobre a diferenciação entre vida doméstica e nãodoméstica, afinal, a vida doméstica é fundamental na determinação das oportunidades acessíveis a cada um. Para Okin, a divisão sexual do trabalho intrafamiliar e os comportamentos e papéis de gênero construídos e perpetuados na vida familiar estão entre os maiores obstáculos à equidade de oportunidades ${ }^{55}$; visão esta compartilhada pela maior parte da teoria feminista, em suas diversas vertentes. Ou seja, feministamente, a premissa liberal igualitária da igualdade moral humana exige uma

\footnotetext{
${ }^{54}$ NAGEL, Thomas. "Rawls and Liberalism". In FREEMAN, Samuel (ed.). The Cambridge Companion to Rawls. Cambridge, Cambridge University Press, 2002, pp. 62-85, trecho retirado de p. 63.

${ }^{55}$ Okin, 1989, p. 14.
} 
segunda ampliação do escopo da justiça - lembrando sempre que esta delimita um espaço de inviolabilidade individual igual -, questionando também a dicotomia público/privado como não-doméstico/doméstico. O liberalismo igualitário rawlsiano traz em si o feminismo em um sentido geral (como o sentido de Okin acima citado), com sua exigência de liberdade e igualdade para as mulheres e reconhecimento lato de que "o pessoal é político", ainda que falte nuançar devidamente o entendimento disso dentro da perspectiva da tolerância liberal às diversas concepções de bem e boa vida e enfatizar que o pluralismo moral é valioso para a vida humana.

Em suma, o que é salientado aqui é que o liberalismo não é incompatível com uma revisão da dicotomia público/privado e nem com a inclusão de estruturas e instituições tradicionalmente concebidas como privadas como parte do escopo da justiça. Isso implica que, diferentemente do que afirma o feminismo radical de Catherine MacKinnon ${ }^{56}$ e de diversas outras autoras, o feminismo não é anti-feminista e, com os devidos ajustes, pode sim lidar com a ubiquidade do gênero. O liberalismo seria incompatível com o feminismo apenas se fosse incapaz de lidar com poderes comumente ditos privados e com a afirmação feminista de que "o pessoal é político". O que será defendido nesta tese é justamente um modo liberal de pensar poderes e coerções privadas como objeto da justiça e, ao mesmo tempo, que este modo liberal é o mais adequado a um feminismo cosmopolita que necessita lidar com o pluralismo moral em sua escala mais vasta, a do globo.

Dito isso, passemos ao problema do privado e pessoal como feministamente "políticos" e "objetos da justiça" de uma perspectiva liberal.

Numa primeira tentativa de clarear os sentidos em que "o pessoal é político" do ponto de vista feminista liberal, podemos considerar que "o pessoal é político" sempre que algo que não é redutível ao estatal é produtor de relações de dominação e poder violadoras de liberdades e direitos, minando as possibilidades de liberdade igual para as pessoas. O caráter "pessoal" do gênero é "político" neste sentido. Destrinchemos melhor as múltiplas faces disso.

\footnotetext{
${ }^{56}$ Vide MacKinnon, 1987, acima citado e MacKINNON, Catharine. Toward a Feminist Theory of State. Cambridge-Mass., Harvard University Press, 1989.
} 
Gênero é relacional e suas relações de poder transcendem inegavelmente os poderes estatais e as construções legais, assim como transcendem qualquer esfera específica da vida, dada a ubiquidade do gênero.

Ao mesmo tempo, gênero é "pessoal” porque é indissociável de estruturas e instituições tradicionalmente consideradas "privadas", como a família, a religião e o mercado de trabalho. Gênero também é pessoal por ser indissociável da construção da identidade das pessoas e das culturas, que também são mais comumente associadas ao privado como não-estatal, ainda que o Estado seja sempre culturalmente embebido. Podemos afirmar que não há identidade pessoal e cultura fora das relações de gênero. Ao mesmo tempo em que podemos dizer também que tudo o que é privado e/ou público passa de algum modo pelo gênero, seja através do poder simbólico do universal masculino e da associação de virtudes e papéis sociais diferentes a mulheres e homens, seja através de leis e políticas públicas que tratem iguais como diferentes ou diferentes como iguais. E, sendo pessoal, privado, legal, estatal ou público, gênero é "político" no sentido de que relações de gênero são relações de poder. Sendo relações de poder, relações de gênero podem sempre ameaçar a esfera de inviolabilidade individual devida a todos.

Gênero também não se reduz a nenhuma concepção de privado e de não-estatal, sendo sim estatalmente construído, reproduzido e consolidado - vide o Direito de família e o Direito Civil, para ficarmos nas formas de legalidade em que o gênero é mais visível; vide também a educação e saúde públicas como áreas de políticas públicas profundamente reprodutoras e transformadoras das relações de gênero. Gênero é pública e estatalmente expresso e construído, ao mesmo tempo em que é privadamente expresso e construído (sem esquecermos de que o próprio Estado é social e culturalmente embebido, expresso e construído). Dada a ubiquidade do gênero, gênero não se reduz a nenhuma esfera da vida. Trataremos brevemente, a seguir, de como gênero e o privado também são estatalmente regulados e constituídos e de como Estado e as leis expressam relações de gênero que os transcendem.

Comecemos por uma analogia pensada a partir de Cass Sunstein. 
Conforme aponta este autor a respeito da ideia de "mercado livre", o "mercado livre", seja como o conhecemos e vivenciamos, seja na forma como é defendido pelos libertarianos, constrói sua existência através do Direito e do Estado que o assegura e depende fundamentalmente das construções jurídicas e políticas. Ainda que não possamos conhecer perfeitamente a origem e a causa dos mercados ${ }^{57}$, o Estado e o Direito fazem parte deles. Leis definem o que é a propriedade, quem tem direito a ela, como ela é legitimamente transferida para outros, atribuindo direitos de propriedade e troca e impondo penalidades a quem não os respeita, estabelecendo quem pode fazer o que com que bem e com quais proprietários de bens. Sem as leis de propriedade, a propriedade não existiria ${ }^{58}$. Sem as leis de contrato, a liberdade de contrato não existiria $^{59}$. O Direito e o Estado soberano que assegura o seu cumprimento constroem e perpetuam o "mercado livre" e são coercitivos no sentido de que, ao mesmo tempo em que permitem e facilitam transações entre pessoas, impedem as pessoas de agirem e se comportarem de muitos modos que gostariam. Ou seja, os mercados devem ser entendidos, entre outras maneiras, como uma construção legal, estatal e social árdua e coercitiva, devendo ser avaliados a partir do modo como afetam e promovem os interesses humanos que valorizamos e não como parte de uma ordem natural que promove interações voluntárias entre as pessoas ${ }^{60}$.

Do mesmo modo, relações de gênero também são jurídica e estatalmente construídas de inúmeras maneiras. Leis definem o que é o casamento e quais são suas regras, desde a monogamia ou poligamia, a quem possui permissão para casar com quem - pais não podem casar com suas filhas, por exemplo, e, na maioria dos países, existe apenas o casamento heterossexual. Também são leis que permitem ou proíbem o divórcio e estabelecem seus termos. Leis também definem os regimes de propriedade e divisão da propriedade intrafamiliar, seja através de leis de herança, leis de pensão para filhos e cônjuges, leis de comunhão e separação de bens etc. São leis que tornam as mulheres juridicamente iguais aos homens de sua família, ou que as obrigam a obedecê-

\footnotetext{
${ }^{57}$ Seria absurdo afirmarmos que o Estado e o Direito são unilateralmente as causas e os criadores do mercado e Sunstein é ciente disso. O Estado e o Direito são socialmente construídos como tudo o que faz parte da sociedade. $\mathrm{O}$ argumento de Sunstein sobre como o Estado determina relações de mercado não o ignora.

${ }^{58}$ Repito que este não é um argumento causal, mas uma afirmação sobre parte da "constituição" social daquilo que a propriedade é.

${ }^{59}$ Repito, novamente, que este não é um argumento causal, mas uma afirmação sobre parte da "constituição" daquilo que são os contratos.

${ }^{60}$ Sunstein, Cass. Free Markets and Social Justice. Oxford, Oxford University Press, 1997, p. 5.
} 
los. Também são leis que definem decisões sobre as guardas dos filhos em caso de divórcio. Sobre as regras trabalhistas relativas à gravidez, maternidade e paternidade e aposentadoria. Tudo isso mostra que a família, instituição central à construção, reprodução e perpetuação do gênero, não é independente do Estado, por mais que não seja causalmente decorrente dele e por mais que o ultrapasse. Conforme aponta Susan Okin a partir de Frances Olsen,

As Frances Olsen has pointed out with great clarity and perceptiveness, the very notion that the state has the option to intervene or not to intervene in the family is not only mythical but meaningless. In many ways "the state is responsible for the background rules that affect people's domestic behaviors." The law does not on the one hand legitimize any and all kinds of behavior within the family - murder being the most obvious example. But neither does it regulate the behavior of family members toward each other in the same way that it regulates the behavior of strangers; for example, parents can 'ground' their children as a means of discipline, or enlist the state's help in restraining children who run away, children cannot sue their parents (as others could) for kidnapping them on such occasions and, as Olsen says, "the staunchest opponents of state intervention in the family will insist that the state reinforce parent's authority over their children." "Because the state is deeply implicated in the formation and functioning of families," she argues, "it is nonsense to talk about whether the state does or does not intervene in the family." On the vital question of divorce, for example, would 'nonintervention' mean allowing divorce, or not allowing it? Making a divorce difficult or easy to acquire? The issue is not whether, but how the state intervenes. The myth that state intervention in the family is an option allows those who support the status quo to call it "nonintervention" and to label policies that would alter it - such as the provision of shelters for battered wives - "intervention." This language takes the focus off more pertinent questions such as whether the policy in question is equitable or prevents harm to the vulnerable. ${ }^{61}$

Mas não é apenas em relação à família que o Estado é parte da construção de gênero. $\mathrm{O}$ mesmo pode ser dito a respeito da legislação trabalhista, penal, de direitos e liberdades civis etc.

A questão da existência ou ausência de direitos trabalhistas relativos à gravidez, maternidade, paternidade e doenças familiares que justificam licenças é parte do que

\footnotetext{
${ }^{61}$ Okin, 1989, pp. 130-131.
} 
constrói a relação entre homens e mulheres intrafamiliarmente e no mercado de trabalho. Este tipo de legislação e divisão sexual do cuidado é levado em consideração nestas duas dimensões do privado: o mercado e a família. Adiciona-se a isso o fato de que não são todas as profissões que estão legalmente abertas a todas as pessoas em todos os países, há profissões vetadas para mulheres e/ou homens e para pessoas de etnias e religiões diferentes em alguns países. Isso ocorria até recentemente na Índia e ocorre em países em que a Sharia vigora juridicamente ou é influente, para citarmos exemplos bastante conhecidos. E, mesmo quando não há interdições legais, algumas profissões são tradicionalmente femininas ou masculinas por motivos culturais que transcendem o estatal e legal.

$\mathrm{Na}$ legislação criminal, muitos países possuem leis que permitem aos homens cometerem violações da integridade física e da liberdade das mulheres em nome da honra familiar e comunitária, comumente entendidas como honra masculina de que as mulheres devem ser guardiãs através de sua modéstia e castidade ${ }^{62}$, por exemplo. Assim, muitas sociedades consideram legítimo que as mulheres não possam ir e vir, trabalhar e manter uma vida social que não seja aprovada pelos homens de sua família e que seus pais, irmãos e maridos as punam caso desrespeitem a autoridade familiar masculina. Muitas também consideram que violência contra as mulheres causadas por relacionamentos amorosos não aprovados ou adultério são legítimas, não constituindo crimes ou recebendo penas fracas. Tudo isso se relaciona com os já mencionados "crimes de honra". O exemplo mais conhecido, novamente, é o dos países cujos Estados possuem forte viés religioso, especialmente os que adotam e defendem a legitimidade da Sharia. Mas o problema não se restringe a eles, afinal, o problema dos crimes de honra existiu por muito tempo no Ocidente e continua existindo, basta lembrarmos as concepções "mediterrâneas de honra"63 e os crescentes assassinatos de honra que ocorrem entre imigrantes na Europa ${ }^{64}$; é claro que o fato de que estes não são legalmente permitidos faz muita diferença para as mulheres que lá vivem.

O Estado também é parte do que conforma a vida interna das religiões e a convivência entre elas, pois os Estados estabelecem direitos individuais e/ou coletivos

\footnotetext{
${ }^{62}$ Conforme citado entre as epígrafes desta tese, "women have to often been treated as the supporters of the ends of others, rather than as ends in their own right" (Nussbaum, 2001, pp. 4-5).

${ }^{63}$ Vide Bourdieu, 2011.

${ }^{64}$ Vide Wikan, 2010.
} 
que aumentam ou diminuem igualdade e liberdades individuais e/ou de grupos e comunidades, com suas hierarquias internas. A liberdade de consciência, a liberdade de expressão, a liberdade de associação e a liberdade religiosa são todas liberdades juridicamente estabelecidas e que dizem respeito às relações interpessoais, às relações das pessoas com as comunidades a que pertencem e às relações entre grupos e comunidades. Um Estado religioso e um Estado laico afetam as possibilidades de vida individual e comunitária e de pertencimento de modos muito distintos. E um Estado que lida universalmente com as pessoas através de direitos individuais é muito diverso de um Estado que estabelece direitos coletivos para comunidades que decidem internamente os direitos de seus membros. Direitos culturais, direitos coletivos, direitos individuais e a vida das religiões e dos grupos culturais são um modo através do qual o Estado, inevitavelmente, faz do privado e do pessoal, políticos.

Se pensarmos com Okin que importa pensarmos na equidade e nas liberdades dos vulneráveis e que o feminismo é a crença de que as pessoas não devem ter desvantagens por seu sexo e que homens e mulheres possuem dignidade igual, devemos lembrar que direitos coletivos e direitos culturais afetam desigualmente os membros das comunidades e que, em especial, afetam desigualmente mulheres e homens e possuem grande potencial antifeminista, dado que a cultura e a religião constroem papeis e comportamentos de gênero desiguais e que as mulheres são as principais portadoras das tarefas de reprodução e cuidado e de manutenção das tradições. Como diz Okin, "advocates of group rights pay little or no attention to the private sphere", negligenciando

the sphere of personal, sexual, and reproductive life functions as a central focus of most cultures, a dominant theme in cultural practices and rules. Religious or cultural groups often are particularly concerned with 'personal law' - the laws of marriage, divorce, child custody, division and control of family property, and inheritance. As a rule, then, the defense of 'cultural practices' is likely to have much greater impact on the lives of women and girls than on those of men and boys, since far more of women's time and energy goes into preserving and maintaining the personal, familial, and reproductive side of life. Obviously, culture is not only about domestic arrangements, but they do provide a major focus of most contemporary cultures. Home is, after all, where much of culture is practiced, preserved, and transmitted to the young. On the other hand, the distribution of responsibilities and power at home has a major impact on who can participate in and influence the more public parts of cultural life, 
where rules and regulations about both public and private life are made. The more a culture requires or expects of women in the domestic sphere, the less opportunity they have of achieving equality with men in either sphere ${ }^{65}$.

Defensores do multiculturalismo e comunitarismo negligenciam a religião e as grandes narrativas religiosas como construções de controle e dominação das mulheres pelos homens, o que pode ser verificado nos interditos religiosos e nas construções religiosas da ideia de mulher das mais diversas religiões ${ }^{66}$. Okin apresenta esta questão a partir dos três grandes monoteísmos: judaísmo, cristianismo e islamismo. Joan Wallach Scott também se detém sobre estas três grandes religiões ${ }^{67}$. Nussbaum discute a mesma questão através do islamismo e do hinduísmo indianos ${ }^{68}$. A importância da religião tradicionalmente vista como um exercício privado - na constituição das pessoas e do gênero é tal que a Igreja é elencada entre principais "instituições" sociais produtoras e perpetuadoras da "dominação masculina" por Bourdieu, junto com a família, a escola e o Estado ${ }^{69}$.

Assim, defender direitos coletivos religiosos, cujos sujeitos de direito são organizações religiosas, em vez de uma interpretação individualista ética da liberdade religiosa, com direitos individuais de apostasia e escolha da própria religião, possui muitas implicações sobre a articulação entre o privado e o público na constituição da coerção cultural, social e política.

As conexões da cultura em geral e da religião em particular com a construção da desigualdade de gênero e da família são aspectos essenciais do modo como o pessoal é político e de como o Estado, ao delimitar e atribuir direitos e liberdades religiosos, inevitavelmente faz parte da constituição do privado.

E tudo aquilo que é parcela estatal da constituição do privado é um uso público da soberania estatal e exige justificação normativa, não podendo ter sua legitimidade ética e política pressuposta. A defesa e construção da privacidade das famílias, das

\footnotetext{
${ }^{65}$ Okin, 1999, pp. 12-13.

${ }^{66}$ Okin, 1999, pp. 13-17.

${ }^{67}$ SCOTT, Joan. The Politics of Veil. Princeton, Princeton University Press, 2007.

${ }^{68}$ Nussbaum, 2006. Nussbaum, Martha. Sex and Social Justice. Oxford, Oxford University Press, 2000. Nussbaum, Martha. "Women and the Law of Peoples." Politics, Philosophy \& Economics 1(3), 2002, pp. 283-306.

${ }^{69}$ Dentro desta pesquisa, todas estas instituições são entendidas como parte da estrutura básica como objeto da justiça, como veremos adiante.
} 
religiões, das associações, das comunidades, das empresas e dos homens não deve violar a construção da privacidade feminina, que também é normativamente valiosa e que é constantemente violada através de atos privados familiares, religiosos, trabalhistas etc. Uma possibilidade é que a relação público/privado moralmente mais adequada seja uma que pense a privacidade em moldes individualistas éticos, isto é, privacidade igual de todos individualmente, mulheres e homens. E não privacidade da entidade "família", da entidade "Igreja", da entidade "empresa" etc. Ou seja, do ponto de vista feminista liberal, é importante que toda legislação e política que regule o comportamento e convivência entre quaisquer pessoas morais - seja entre indivíduos, entre indivíduos e seus grupos, entre grupos, entre indivíduos e instituições e entre instituições - seja orientada individualistamente pela afirmação de um plano de dignidade humana igual que transcenda o gênero como relação de poder.

Isso independe de perspectivas feministas de "ética do cuidado", pois o fato das mulheres se construírem identitária e privadamente através do cuidado não implica que, em caso de violações, não devam ser estatal e socialmente protegidas dentro de uma lógica pública de direitos e necessidades individuais. Como afirma Martha Nussbaum, apesar da família e da religião serem cultural, social e coletivamente valiosas, a abordagem universalista, não necessita se apoiar sobre nenhuma tradição metafísica e não precisa ter nenhum viés contra o amor e o cuidado (ou pró concepções masculinas de mundo), precisa apenas tratar cada ser humano como um fim em si mesmo e perceber que as pessoas são separadas no sentido de que a comida no estômago de A não alimenta o corpo de $\mathrm{B}$ e o prazer sentido pelo corpo de $\mathrm{C}$ não alivia a dor sofrida pelo corpo de $\mathrm{D}^{70}$. E nada mais pessoal e privado do que as relações familiares, religiosas, comunitárias e culturais que constroem o que cada pessoa é e que são uma expressão simultânea do caráter público da família, da religião e da cultura e do caráter privado do que é estatalmente circunscrito. A privacidade só é compatibilizada com a dignidade humana igual de homens e mulheres quando a justiça dá conta desta mescla e composição mútua entre público e privado que são mais do que dicotômicos.

\footnotetext{
${ }^{70}$ Nussbaum, 2001, p. 56.
} 


\section{Primeira aproximação entre gênero e estrutura básica como objeto da justiça}

Em Justice, Gender, and the Family, Susan Okin elenca três motivos pelos quais gênero e família são uma questão de justiça e, portanto, no arcabouço conceitual que esta autora incorpora de Rawls, devem ser "objeto da justiça" e parte da "estrutura básica da sociedade", composta pelas principais instituições políticas, econômicas e sociais que determinam as perspectivas de vida disponíveis a cada posição social:

1. as mulheres devem ser completamente incluídas em qualquer teoria satisfatória da justiça;

2. a equidade de oportunidades é impedida pelas injustiças de gênero;

3. a família é uma engrenagem central da estrutura de gênero e deve ser justa para que a sociedade também o seja ${ }^{71}$.

No entanto, incluir gênero como preocupação de justiça é mais do que incluir a família como objeto da justiça, dada a ubiquidade do gênero.

Como a própria Okin salienta em Is Multiculturalism Bad for Women? toda a cultura é construtora do gênero, entendido por ela como "institucionalização social da diferença sexual". É por isso que proteger minorias religiosas e culturais através de direitos coletivos é proteger estatal e legalmente desigualdades de gênero, afinal

Though they may not impose their beliefs or practices on others, and though they may appear to respect the basic civil and political liberties of women and girls, many cultures do not, especially in the private sphere, treat them with anything like the same concern and respect with which men and boys are treated, or allow them to enjoy the same freedoms. Discrimination against and control of the freedom of females are practiced, to a greater or lesser extent, by virtually all cultures, past and present, but specially by religious ones and those that look to the past - to ancient texts or revered traditions - for guidelines or rules about how to live in the contemporary world ${ }^{72}$.

Este mesmo problema reaparece em sua crítica a $O$ Liberalismo Político de Rawls, na qual Okin afirma que as doutrinas abrangentes de bem devem ser julgadas a

\footnotetext{
${ }^{71}$ Okin, 1989, p. 14.

72 Okin, 1999, p. 21.
} 
partir do prisma da afirmação moral da igualdade de gênero e que a afirmação da igual dignidade de mulheres e homens deve ser um critério definidor da razoabilidade das concepções de boa-vida e das religiões ${ }^{73}$.

Como veremos adiante, em Rawls, a razoabilidade é uma característica das sociedades democráticas liberais, nas quais os cidadãos são vistos como livres e iguais; e doutrinas abrangentes razoáveis são aquelas que não requerem que o poder coercitivo estatal seja usado para impor suas concepções sobre o bem sobre outros. Para Okin, este critério não é suficiente de uma perspectiva feminista, pois admite como razoáveis religiões profundamente ancoradas em visões anti-igualitárias de gênero e desfavoráveis as mulheres. Segundo ela,

Only by allowing that his principles of justice apply directly to the internal life of families - which Rawls clearly resists - and by restricting 'reasonable conceptions of the good' to those that are nonsexist, could one revise the theory so that it both includes women and has an effective and consistent account of moral development" (pp. 1638-1539).

Discutiremos esta questão adiante. No momento, o que nos importa é apenas que para a própria Okin reduzir o problema de gênero a incluir a família como instituição pertencente ao objeto da justiça não esgota o problema da inclusão feminista das mulheres em um teoria normativa que lide adequadamente com a igual liberdade para todos. A família, ainda que fundamental, não diz respeito a toda a questão do gênero seja como a "institucionalização social da diferença sexual", nos termos de Okin, seja como "organização social da relação entre os sexos", nos termos de Joan Scott.

Pierre Bourdieu, em A Dominação Masculina, aponta como principais instituições responsáveis pela "dominação masculina" a família, a Igreja, a Escola e o Estado. Para ele, são estas as instituições para as quais as feministas devem se voltar, por serem as principais responsáveis pela construção da aceitação e reprodução da desigualdade de gênero tanto pelos homens quanto pelas próprias mulheres, ou seja, pela construção e perpetuação daquilo que este autor chama de "paradoxo da dóxa":

o fato de que a ordem do mundo, tal como está, com seus sentidos únicos e seus sentidos proibidos, em sentido próprio ou figurado, suas

\footnotetext{
73 OKIN, Susan Moller. "Justice and Gender: An unfinished debate." Fordham Law Review. Symposium Rawls and the Law. Vol. LXXII, Number 5, April 2004, 1537-1567.
} 
obrigações e suas sanções, seja grosso modo, respeitada, que não haja um maior número de transgressões ou subversões, delitos e 'loucuras' (...); ou, o que é ainda mais surpreendente, que a ordem estabelecida, com suas relações de dominação, seus direitos e suas imunidades, seus privilégios e suas injustiças, salvo uns poucos acidentes históricos, perpetue-se apesar de tudo tão facilmente, e que condições de existência das mais intoleráveis possam permanentemente ser vistas como aceitáveis ou até mesmo como naturais. (...) sempre vi na dominação masculina, e no modo como é imposta e vivenciada, o exemplo por excelência desta submissão paradoxal, resultante daquilo que eu chamo de violência simbólica, violência suave, insensível, invisível a suas próprias vítimas, que se exerce essencialmente pelas vias puramente simbólicas da comunicação e do conhecimento, ou, mais precisamente, do desconhecimento, do reconhecimento ou, em última instância, do sentimento. ${ }^{74}$

A reunião da família, religião, escola e Estado como "instituições" que são centrais na construção da "dominação de gênero" é particularmente interessante para pensarmos o problema do "objeto da justiça" como a "estrutura básica da sociedade", formada pelas "principais instituições políticas, econômicas e sociais" que dão as alternativas de vida disponíveis às diversas posições sociais. É interessante por acentuar o aspecto "institucional" da construção social das relações de gênero sem descuidar

1. do aspecto atitudinal e ancorado nas escolhas, crenças e comportamentos das pessoas, unindo o aspecto "institucional" que é central ao conceito de estrutura básica de Rawls ao problema das desigualdades e injustiças que são construídas através dos padrões de escolhas, comportamentos e ações pessoais com os quais G. A. Cohen se preocupa ao frisar que não podemos negligenciar o fato de que não são apenas instituições coercitivas estatais que constroem a desigualdade, mas as próprias atitudes pessoais no mercado, na família e em tudo o que vive junto às instituições sem ser diretamente ordenado por elas - como o comportamento maximizador de mercado ou a divisão sexual do trabalho intrafamiliar;

2. e do aspecto sociocultural da construção do gênero que é apontado pela própria Susan Okin em sua crítica a $O$ Liberalismo Político de Rawls por este não submeter as concepções de bem ao escrutínio valorativo do modo como estas são ou podem ser anti-igualitárias frente ao gênero.

\footnotetext{
${ }^{74}$ Bourdieu, 2011, pp. 7-8.
} 
Esta argumentação é independente de quais são exatamente os papéis causais e as determinantes do gênero, questão esta que não seria possível responder através da teoria política normativa e de teorias ideais da justiça. Importa para esta tese, especificamente, (1) o modo como, ubiquamente, o gênero faz parte da atribuição de encargos e benefícios da cooperação social em seus aspectos anti-igualitários e antiliberais e (2) o modo como esta ubiquidade transpassa instituições e comportamentos e escolhas pessoais que se relacionam fortemente, ainda que não se reduzam um ao outro. E estes dois aspectos transparecem nos conceitos de gênero de Joan Scott e Susan Okin, assim como na teorização sociológica de Bourdieu, muito afinada com a da feminista radical Catherine MacKinnon ${ }^{75}$, sempre citada por ele e para quem o cerne da desigualdade de gênero seria a "alienação da sexualidade feminina" que construiria a "supremacia masculina" e estaria impressa ubiquamente em toda a sociedade. É esta ubiquidade, que faz parte da construção de uma distribuição desigual e orientada por gênero das liberdades, encargos e benefícios da cooperação social, seja qual for a sua base - a família, a religião, a sexualidade ou as instituições elencadas por Bourdieu que

$$
\begin{aligned}
& \text { deve ser incluída no "objeto da justiça", } \\
& \text { acessada por "meios para a justiça" que sejam } \\
& \text { institucionalmente tolerantes e justos e } \\
& \text { acessada por "princípios de justiça" igualitários e liberais. }
\end{aligned}
$$

Dentro desta necessidade teórico-normativa feminista e liberal-igualitária, temos como primeiro ponto importante que, do ponto de vista da "justiça como equidade"76 que gênero é paulatinamente consolidado como uma arbitrariedade moral, isto é, como algo que do ponto de vista da justiça, não justifica atribuição desigual de encargos e benefícios da cooperação social através das coerções inescapáveis da estrutura básica da sociedade.

Rawls é ambíguo quanto à inclusão da família como objeto de justiça, ela aparece explicitamente na primeira parte de Uma Teoria da Justiça, não é tratada na segunda parte deste livro, sobre Instituições, e reaparece na terceira parte como locus de aprendizado moral. Esta ambiguidade é atenuada em Justiça como Equidade e na Ideia

\footnotetext{
${ }^{75}$ MacKinnon, 1987.

${ }^{76}$ A teoria da justiça de Rawls.
} 
de Razão Pública Revista, em que Rawls afirma que a família é uma associação e, como tal, pode ser regida por critérios outros que não o segundo princípio (diretamente voltado à justiça distributiva), mas que não é isenta de justiça. Conforme citado nas epígrafes deste trabalho, "if the so-called private sphere is alleged to be a space exempt from justice, then there is no such thing" igreja, nem qualquer comunidade ou grupo cultural, nem qualquer tipo de associação está além da justiça, por mais que o pluralismo moral razoável deva ser respeitado e que seja normativamente tolerante e valioso preservarmos um espaço para motivações pessoais e comunitárias diversas das motivações morais impressas em arranjos coercitivos institucionais justos, isto é, arranjos institucionais regidos pelo respeito ao axioma da igualdade humana fundamental. Poderíamos dizer, preliminarmente, que este espaço que não é isento de justiça, por não poder violar a igualdade moral universal e, portanto, respeitar o direito de saída e as liberdades básicas das pessoas, é o "âmbito do pessoal que não é político" e que difere do "pessoal é político" feminista, que diz respeito ao pessoal das relações de poder inescapáveis e violadoras de liberdade. A esfera de liberdade deste "pessoal que não é político" é conforme o espaço de inviolabilidade individual fundado na justiça e é o espaço do pluralismo moral razoável e moldado pela tolerância liberal e pelo individualismo ético.

E este "pessoal não político" está presente no liberalismo rawlsiano por seu respeito ao pluralismo moral razoável e por sua valorização de um espaço de liberdade básicas protegido pelo seus princípios de justiça, que visam assegurar não apenas liberdade civis e políticas básicas - como o direito de ir e vir, a liberdade de consciência, a liberdade de expressão, a liberdade de associação e demais liberdades liberais básicas - como o valor equitativo de seu exercício através da equidade de oportunidades e de todo o seu sistema de justiça distributiva.

Ao mesmo tempo, o "pessoal político" está presente em toda a obra de Rawls e, frequentemente, por motivos caros ao feminismo. (1) $\mathrm{Na}$ especificação das arbitrariedades morais - entre as quais estão gênero, etnia, classe e demais atributos físicos e sociais - que não devem constranger as possibilidades de vida, liberdade e bem-estar das pessoas através das coerções inescapáveis da estrutura básica. (2) No fato da família ser citada como parte da estrutura básica como objeto da justiça em diversas

\footnotetext{
${ }^{77}$ Rawls, 2005, p. 471.
} 
partes de sua obra. (3) Pela família ser considerada um locus importante de aprendizado moral necessário à estabilidade da justiça. (4) $\mathrm{Na}$ demanda normativa de que as religiões e concepções de bem sejam razoáveis e tolerantes, respeitando as liberdades das pessoas, em particular o direito à apostasia. Rawlsianamente, as religiões devem respeitar um critério de razoabilidade que, ainda que não inclua a crença na igualdade de crença, inclui a exigência de que aceitem a apostasia e não exijam que o Estado use seu poder coercitivo para impor as suas regras sobre os demais cidadãos, ou seja, pela razoabilidade, o Estado não pode impor regras de modéstia feminina nem mesmo quando estas forem muito importantes para as doutrinas religiosas. 


\section{Gênero e os âmbitos da justiça: pessoal, local, social e cosmopolita}

Pois bem, dada a percepção feminista da ubiquidade do gênero e as relações de gênero como coercitivas e dada a noção rawlsiana de "inviolabilidade individual fundada na justiça" e que deve ser conforme o "axioma da igualdade humana fundamental", esta tese pensará normativamente os planos pessoal, local, social e cosmopolita e questionará as fronteiras entre eles. Esta seção estabelecerá preliminarmente o que são estes quatro planos.

Seguindo Rawls, pensaremos a "justiça local” a partir de Jon Elster. Para quem a "justiça local" diz respeito à alocação descentralizada de bens escassos e encargos necessários. Seus problemas são locais em três sentidos:

1. obedecem princípios de alocação que diferem conforme as esferas;

2. em uma mesma esfera, os princípios são diversos conforme os países;

3. pode haver variação local considerável mesmo dentro de um só país ${ }^{78}$.

Utilizamos o termo "justiça local” de Elster neste trabalho em decorrência de seu uso por Rawls em Justiça como Equidade - Uma reformulação ${ }^{79}$, livro no qual Rawls diferencia os princípios de justiça endereçados à estrutura básica (âmbito da "justiça social”) daqueles que são endereçados "às associações, instituições e práticas sociais em geral". Citando-o:

Temos ao todo, de dentro para fora, três níveis de justiça: primeiro, a justiça local (os princípios que se aplicam diretamente a instituições e associações); segundo, a justiça doméstica (os princípios que se aplicam à estrutura básica da sociedade); e, por fim, a justiça global (os princípios de justiça que se aplicam ao direito internacional) ${ }^{80}$.

Rawls afirma que seus princípios de justiça não se aplicam à justiça local porque são endereçados apenas ao que é coercitivamente inescapável e, portanto, não a associações e comunidades aos quais o pertencimento é considerado voluntário pela

\footnotetext{
${ }^{78}$ ELSTER, Jon. "Local Justice. How to allocate scarce goods and necessary burdens." European Economic Review 35(1991), pp. 273-291.

${ }^{79}$ RAWLS, John. Justiça como Equidade. Uma reformulação. São Paulo, Martins Fontes, 2003.

${ }^{80}$ Rawls, 2003, pp. 15-16.
} 
possibilidade de saída. Assim, neste esquema, famílias, igrejas e comunidades não precisam ser reguladas pelos princípios da "justiça como equidade"

Do mesmo modo, as escolhas individuais também não precisam ser reguladas por eles, é isso o que aqui chamo de âmbito do "pessoal" e que, dentro do pluralismo moral razoável e do auto-interesse razoável, é um espaço de escolha não constrangida publicamente por princípios universais liberais e igualitários de justiça.

A única área que é "objeto" dos princípios rawlsianos de justiça é a estrutura básica da sociedade, que compõe um arranjo de instituições políticas, econômicas e sociais coercitivas e inescapáveis que dão as possibilidades de vida disponíveis às diversas posições sociais. Este é o escopo rawlsiano da "justiça social”, cuja interpretação será amplamente discutida ao longo de toda esta tese.

Sendo que, rawlsianamente, o plano cosmopolita também foge ao plano da justiça, já que, para Rawls, (1) as relações internacionais não possuem interdependência, cooperação e coerções inescapáveis similares às internas aos países, com seus Estados soberanos e (2) iria contra o "espírito de tolerância liberal" impor internacionalmente aos povos de todos os países que respeitem critérios universalistas e individualistas de direitos e liberdades básicas devidos a todos ${ }^{82}$.

A proposta desta tese se distancia deste pluralismo de escopos da justiça por razões feministas e cosmopolitas, ainda que se pretenda rawlsiana em espírito.

Como a desigualdade e as coerções de gênero (1) são profundas e podem ameaçar o "espaço de inviolabilidade individual fundado na justiça", (2) transcendem instituições formais estatais e são construídas através de diversas instituições - como as famílias, as igrejas e associações e comunidades culturais - que não são inequivocamente parte da estrutura básica segundo Rawls e (3) que são frequentemente consideradas por ele "associações" e "comunidades" de pertencimento "voluntário" que pertencem ao âmbito da "justiça local", feministamente, alargaremos o escopo da "justiça social" através de uma interpretação expandida da "estrutura básica" como "objeto da justiça".

\footnotetext{
${ }^{81}$ Estes princípios são expostos na pp. 118-119.

82 Rawls, John. O Direito dos Povos. São Paulo, Martins Fontes, 2001.
} 
Como os diversos Estados dos diversos países do mundo são inequivocamente coercitivos e não podemos pressupor que seus poderes soberanos e suas estruturas básicas sejam legítimas e respeitadoras da "inviolabilidade individual fundada na justiça" e nem que o interesse de todos os Estados sejam conforme liberdades e interesses básicos de seus cidadãos, cosmopolitamente, alargaremos o escopo da "justiça social" ao considerar que esta deve ser um valor normativo respeitado por todos os países do mundo. Portanto, inicialmente, adotaremos definição de cosmopolitismo proposta por Kok-Chor Tan, que afirma que,

Cosmopolitanism, as a normative idea, takes the individual to be the ultimate unit of moral concern and to be entitled to equal consideration regardless of nationality and citizenship. From the cosmopolitan perspective, principles of justice ought to transcend nationality and citizenship, and ought to apply equally to all individuals of the world as a whole. In short, cosmopolitan justice is justice without borders. ${ }^{83}$

Assim, sinteticamente, podemos afirmar, preliminarmente, que esta tese questiona o pluralismo de escopo entre o pessoal, o local, o social e o cosmopolita, subordinando-os todos - e todas as relações entre pessoas morais neles inclusas - ao axioma da igualdade moral humana.

Isso é importante do ponto de vista feminista porque, dada a ubiquidade do gênero,

- o "local” é coercitivo e violador de liberdades básicas em todos os países do mundo e

- o "social" - seja estatal, público ou privado - é coercitivo em todos os países do mundo

e o feminismo, conforme define Susan Okin, acredita que mulheres e homens possuem direito às mesmas liberdades sempre.

\footnotetext{
${ }^{83}$ TAN, Kok-Chor. Justice without Borders. Cosmopolitanism, nationalism and patriotism. Cambridge, Cambridge University Press, 2004, p. 1.
} 


\section{Estrutura básica, coerção e gênero como objeto da justiça: o monismo moral em uma perspectiva feminista e cosmopolita}

O primeiro ponto de partida normativo deste trabalho já foi anunciado: pensamos o dever ser e a moralidade política da perspectiva do individualismo ético e assumimos o axioma da igualdade moral humana. Isso dá o "horizonte de justificação" 84 que será construído paulatinamente ao longo deste paper, num questionamento das fronteiras teórico-normativas entre as justiças local, social e global. Assim, as perguntas são: se a moralidade política parte do axioma da igualdade moral humana, o que une e o que separa estes três âmbitos da justiça e da igualdade e liberdade humanas?

a partir da relação entre estes domínios normativos, o que é moralmente arbitrário em cada um destes âmbitos?

Vejamos brevemente os horizontes de justificação e âmbitos da justiça social e do direito dos povos rawlsianos.

Em Uma Teoria da Justiça ${ }^{85}$, Rawls afirma que "cada pessoa possui uma inviolabilidade fundada na justiça que nem o bem-estar de toda a sociedade pode desconsiderar" ${ }^{\prime \prime 6}$, é esta "inviolabilidade" igual, posto que pertencente a "cada pessoa", que deve ser protegida pelos princípios de justiça, que "são um modo apropriado de atribuir direitos e deveres nas instituições básicas da sociedade e definem a distribuição apropriada dos benefícios e dos encargos da cooperação social" ${ }^{\text {87 }}$. Há aqui uma afirmação normativa da igualdade humana fundamental e do individualismo ético que

\footnotetext{
${ }^{84}$ Termo de Onora O'Neill que designa os âmbitos (doméstico e internacional) para os quais olhamos quando pensamos a justiça e a moralidade política (O'Neill, 1988).

${ }^{85}$ RAWLS, John. Uma Teoria da Justiça. São Paulo, Martins Fontes, 2008.

${ }^{86}$ Rawls, 2008, p. 5.

${ }^{87}$ Rawls, 2008, p. 5.
} 
permeia toda a sua teoria da "justiça como equidade" ${ }^{88}$, construída para o plano interno das "sociedades liberais" ou "sociedades democráticas" 89 e um entendimento da justiça atrelado a esta igualdade e à noção de que a justiça regula a "cooperação social" e é "a virtude primeira das instituições sociais" "90, referindo-se a uma inviolabilidade igual institucional que vincula simultaneamente a justiça à igualdade e à cooperação social.

As instituições são justas quando não se fazem distinções arbitrárias entre pessoas na atribuição dos direitos e dos deveres fundamentais, e quando as leis definem um equilíbrio apropriado entre as reivindicações das vantagens da vida social que sejam conflitantes entre $\mathrm{si}^{91}$.

A vida social é uma forma de cooperação inescapável e que age através da estrutura básica da sociedade, que é o "objeto principal da justiça"

A estrutura básica é o principal objeto da justiça porque suas consequências são profundas e estão presentes desde o início. Aqui a ideia intuitiva é que essa estrutura contém várias posições sociais e que as pessoas nascidas em condições diferentes têm expectativas diferentes de vida, determinadas, em parte, tanto pelo sistema político quanto pelas circunstâncias econômicas e sociais. Assim, as instituições da sociedade favorecem certos pontos de partida mais que outros. Essas desigualdades são profundas. Além de universais, atingem as oportunidades iniciais de vida, não podem ser justificadas recorrendo-se à ideia de mérito. É a essas desigualdades, supostamente inevitáveis na estrutura básica de qualquer sociedade, que se devem aplicar em primeiro lugar os princípios da justiça social. Esses princípios, então, regem a escolha de uma constituição política e os elementos principais do sistema econômico e social. A justiça de um arranjo social depende, em essência, de como se atribuem os direitos e os deveres fundamentais e também as oportunidades econômicas e das condições sociais dos diversos setores da sociedade ${ }^{92}$.

Há diferentes ênfases na definição de estrutura básica ao longo de toda a obra de Rawls e nas diversas listagens das instituições que fazem parte dela. Unindo as diversas passagens há sempre o fato de que a estrutura básica é inescapável, que participarmos

\footnotetext{
${ }^{88}$ Sua teoria da justiça para o plano interno às sociedades liberais e para a qual foram formulados seus dois princípios de justiça, expostos nas pp. 118-119.

${ }^{89}$ Sociedade liberais e sociedades democráticas são designações para sociedade bem-ordenadas regidas por uma concepção política de justiça.

${ }^{90}$ Rawls, 2008, p. 4.

${ }^{91}$ Rawls, 2008, p. 6.

92 Rawls, 2008, pp. 8-9.
} 
dela é involuntário e, a não ser arcando com grandes ônus próprios à imigração, asilo e refúgio, entramos nela ao nascer e saímos ao morrer, colaborando sempre para a sua reprodução e recebendo dela o quinhão distributivo e de direitos e deveres que ela coercitivamente permite à nossa posição social. O caráter involuntário de nossa participação na estrutura básica faz com que ela não seja uma associação, como "são" ou seriam idealmente diversas instituições que fazem parte da estrutura básica, como universidades, igrejas, empresas, famílias e clubes, às quais podemos nos vincular ou desvincular voluntariamente. Assim, conforme exposto em Justiça como Equidade

Não se deve presumir de antemão que princípios que são razoáveis e justos para a estrutura básica também o sejam para instituições, associações e práticas em geral. Embora os princípios de justiça como equidade imponham limites a esses arranjos sociais da estrutura básica, a estrutura básica e as associações e formas sociais que nela existem são governadas, cada qual, por princípios distintos devido a seus objetivos e propósitos diferentes e sua peculiar natureza e exigências singulares. A justiça como equidade é uma concepção política, não geral, de justiça: aplica-se primeiro à estrutura básica e considera que essas outras questões de justiça local, assim como questões de justiça global (que denomino direito dos povos), exigem considerações de mérito independentes ${ }^{93}$.

Assim como a estrutura básica não se confunde com associações, não se trata de uma "comunidade", posto que a teoria rawlsiana da justiça lida com "sociedade liberais" ou "sociedades democráticas" e não com sociedades que estejam unidas na busca de valores e objetivos comuns próprios às comunidades" ${ }^{94}$. A "justiça como equidade" é própria de uma "sociedade política democrática", na qual convivem diversas "comunidades" e cujos valores e objetivos comuns a todas as pessoas e comunidades são apenas a própria "concepção política de justiça", este valor político comum é o único que é implementado estatalmente e se imprime sobre todo o dever ser da estrutura básica ${ }^{95}$ e é um valor de "prioridade do justo" sobre as diversas concepções de bem. Assim, nascemos em uma sociedade na qual uma estrutura básica determina parte substancial de nossas possibilidades de vida, nascemos também em "associações" e "comunidades" que existem sob esta estrutura básica e que são famílias, religiões e suas culturas próprias, mas "apenas a sociedade com sua forma política de governo e

\footnotetext{
${ }^{93}$ Rawls, 2003, p. 15. Lembrando que Rawls remete o seu uso do termo "justiça local” a Elster.

${ }^{94}$ Noto aqui que, na concepção de "sociedade" de Nussbaum, sociedades são sistemas de cooperação que buscam o bem.

${ }^{95}$ Rawls, 2003, pp. 28-29.
} 
suas leis exerce um poder coercitivo" "96. Podemos abandonar voluntariamente nossas comunidades familiares e religiosas, a apostasia não é crime, mas "há um sentido segundo o qual não podemos abandonar nossa sociedade política voluntariamente" 97 .

A sociedade política é aquela perante a qual somos iguais em liberdade, é a sociedade que encarna a igualdade humana fundamental através dos princípios de justiça igualitária que devem reger a estrutura básica da qual não podemos voluntariamente sair. Diversamente, nas comunidades que não são políticas e nas associações que também não o são, pode ser legítimo sermos tratados desigualmente, dependendo dos valores e objetivos comuns não políticos que unem estas comunidades e associações. Junto com esta legitimidade da desigualdade intra-associações e intracomunidades sob a estrutura básica da sociedade, há uma sociedade política justa que nos permite sair dessas associações e comunidades, imprimindo um tipo de caráter voluntário a estes pertencimentos que podem ser desiguais ${ }^{98}$. Nas palavras de Rawls,

Uma comunidade pode recompensar ou destacar seus membros de acordo com sua contribuição para os valores e objetivos comuns; mas numa sociedade democrática não existem valores e objetivos comuns (que se enquadrem na categoria do bem) por meio dos quais seus cidadãos possam ser distinguidos. Todos aqueles capazes de ser membros plenamente cooperativos da sociedade política são vistos como iguais e só podem ser tratados de forma diferenciada tal como a concepção política pública o admite ${ }^{99}$.

Uma sociedade democrática não pode ser uma comunidade devido à junção do pluralismo moral com a igualdade humana fundamental. Em uma sociedade democrática na qual ocorre o livre uso da razão, sempre florescerão diferentes concepções de bem e formar-se-ão diversas comunidades, o pluralismo moral é inevitável e mesmo valioso para a igualdade moral humana. Para que esta seja realmente uma igualdade de liberdade, é preciso que os princípios de justiça aplicados à estrutura básica façam com que as comunidades funcionem como associações, isto é, como grupos nos quais o pertencimento é voluntário, o que só ocorre caso o direito de saída seja realmente efetivo em respeito à inviolabilidade individual que é exigência normativa imposta pelo valor último da igualdade humana fundamental.

\footnotetext{
${ }^{96}$ Rawls, 2003, p. 28.

${ }^{97}$ Rawls, 2003, p. 28.

${ }^{98}$ Rawls, 2003, pp. 28-29.

${ }^{99}$ Rawls, 2003, pp. 28-29.
} 
Tudo isso coloca a justiça rawlsiana como uma virtude institucional restringida ao que é "político", permitindo o pluralismo das concepções de bem. Como virtude institucional cujo objeto se restringe à estrutura básica, é pensada por Rawls como distinta da "justiça local” e da "justiça global". Assim, conforme expõe Thomas Nagel,

Rawls argued that the liberal requirements of justice include a strong component of equality among citizens, but that this is a specifically political demand, which applies to the basic structure of a unified nation-state. It does not apply to the personal (nonpolitical) choices of individuals living in such a society, nor does it apply to the relations between one society and another, or between the members of different societies. Egalitarian justice is a requirement on the internal political, economic, and social structure of nation-states and cannot be extrapolated to different contexts, which require different standards ${ }^{100}$.

Dentro deste modo de pensar normativamente, devemos pensar diferentemente objetos normativos distintos, ou seja, não devemos aplicar os mesmos critérios e padrões de dever ser a diferentes objetos (as escolhas pessoais não-políticas, o local, o social/doméstico e o global). É esta postura que Nagel chama de anti-monismo ${ }^{101}$, Liam Murphy chama de "anti-monismo" ou "dualismo"102 e Samuel Sheffler denomina "pluralismo" (termo mais preciso, dado que a divisão não se dá apenas entre duas áreas de relações que são objeto de avaliação ética) ${ }^{103}$.

O “monismo", em uma noção que Nagel desenvolve a partir de Liam Murphy, é a postura teórico-normativa para a qual as reflexões político-morais, fundamentalmente, devem avaliar a justiça das instituições a partir de princípios normativos que também se aplicam às escolhas das pessoas ${ }^{104}$. Nas palavras de Murphy,

any plausible overall political/moral view must, at the fundamental level, evaluate the justice of institutions with normative principles that apply also to people's choices. We should not think of legal, political,

\footnotetext{
${ }^{100}$ NAGEL, Thomas. "The Problem of Global Justice". Philosophy \& Public Affairs 33, no. 2, 2005, pp. 113147 (citação da pp. 114-115).

${ }^{101}$ Os conceitos de monismo e anti-monismo de Nagel são desenvolvidos a partir das noções de Liam Murphy em "Institutions and the Demands of Justice", Philosophy \& Public Affairs 27, 1998, pp. 251-291. Esta é uma discussão que insere no debate a respeito da estrutura básica e das escolhas e atitudes pessoais e de qual deve ser o "objeto primário da justiça". Thomas Nagel relê este debate para pensar a diferença entre "justiça política" (doméstica) e "justiça cosmopolita" (vide especificamente Nagel, 2005, pp. 122-126).

102 Murphy, 1998.

${ }^{103}$ SCHEFFLER, Samuel. "Is the Basic Structure Basic?" In SPYNOWICH (org.). The Egalitarian Conscience: Essays in honour of. G. A. Cohen. Oxford, Oxford University Press, 2006, pp. 102-129.

${ }^{104}$ Murphy, 1998, pp. 253-254.
} 
and other social institutions as together constituting a separate normative realm, requiring separate normative first principles, but rather primarily as the means that people employ the better to achieve their collective political/moral goals. ${ }^{105}$

Isso se distingue da posição "dualista" ou "pluralista" que é assumida por Rawls, para quem é importante, do ponto de vista da justiça liberal, que exista

an institutional division of labor between the basic structure and the rules applying directly to individuals and associations and to be followed by them in particular transactions. If this division of labor can be established, individuals and associations are then left free to advance their ends more effectively within the framework of the basic structure, secure in the knowledge that elsewhere in the social system the necessary corrections to preserve background justice are being made. $^{106}$

Este "dualismo" ou "pluralismo" é normativamente importante por pelo menos três motivos. (1) Ele preserva uma esfera de pluralismo moral, na qual as pessoas são livres para se guiarem por princípios éticos diversos, o que é fundamental para a noção de tolerância liberal e de justiça liberal. (2) Permite que as pessoas persigam interesses econômicos particulares, o que envolve, entre outras escolhas de vida, o direito à livre escolha profissional e decisão sobre o grau de dedicação à carreira e trabalho dentro da composição geral da vida cotidiana. (3) Atenta para o fato de que condutas pessoais e transações entre indivíduos que não violam regras de conduta ética não são suficientes para que exista justiça social, ou seja, mesmo que ninguém viole a liberdade alheia e não cometa crimes, ainda assim é possível que a sociedade seja profundamente desigual, sendo necessários estruturas institucionais que preservem a justiça de fundo ${ }^{107}$.

\footnotetext{
105 Murphy, 1998, p. 253.

${ }^{106}$ RAWLS, John. "The Basic Structure as Subject". American Philosophical Quarterly, Vol. 14, No. 2 (1977), pp. 159-165. A citação acima encontra-se na p. 164.

${ }^{107}$ Vide debate entre Rawls e Nozick em torno do exemplo de Wilt Chamberlain formulado pelo último. Nozick imagina uma situação inicial hipotética em que todos possuem o quinhão distributivo considerado mais justo pelo leitor (o exemplo serve para qualquer teoria de justiça distributiva), na qual Wilt Chamberlain decide que só continuaria jogando se, a cada partida, recebesse 25 centavos do preço de cada ingresso vendido. Dada a enorme popularidade de Wilt Chamberlain, devida a seu enorme talento, essa condição é aceita e, ao término da temporada, o jogador teria uma porção da riqueza daquela sociedade superior a de todos os demais e isso ocorreria porque as pessoas livremente escolheram assistir Wilt Chamberlain. Com este exemplo hipotético, Nozick pretende provar que "patterned principles of distributive justice", como os rawlsianos e dos demais igualitarismos, diminuem a liberdade individual. Este exemplo causou grande debate, com respostas formuladas por Rawls, G. A. Cohen e outros sobre como princípios que estabelecem padrões de justiça distributiva preservam a
} 
Ao restringir o objeto de sua teoria da justiça à estrutura básica da sociedade e afirmar que a justiça local, a doméstica e a global devem ser pensadas distintamente, Rawls adota um anti-monismo moral segundo o qual âmbitos e relações diferentes devem ser acessados diferentemente pelas reflexões de moralidade política. Segundo Nagel,

Rawls's anti-monism is essential to understanding both his domestic theory of just society and his view of the relation between domestic and international principles, as expressed in The Law of Peoples. His two principles of justice are designed to regulate neither the personal conduct of individuals living in a just society, nor the governance of private associations, nor the international relations of societies to one another, but only the basic structure of separate nation-states. It is the nature of sovereign states, he believes, and in particular their comprehensive control over the framework of their citizens' lives, that creates the special demands for justification and the special constraints on ends and means that constitute the requirements of justice ${ }^{108}$.

Segundo Nagel, essencialmente, este anti-monismo rawlsiano seria a rejeição teórica da necessidade de consistência entre os diversos planos normativos ${ }^{109}$, consistência esta que é exigida pelas "concepções cosmopolitas" de justiça, mas não pelas "concepções políticas" de justiça. Em sua definição de cosmopolitismo, este seria a afirmação de que as demandas de justiça advêm sempre de uma igual preocupação moral e dever de equidade devidos por cada um de nós a todos os seres humanos e que as instituições às quais os padrões de justiça se aplicam são instrumentos de cumprimento deste dever, que está acima das fronteiras estatais e é pré-institucional ${ }^{110}$.

Podemos afirmar que diversas vertentes feministas exigem esta mesma consistência entre os diversos planos normativos ao afirmarem que a família, a religião e a cultura devem ser conforme a igualdade de gênero e ao criticarem a dicotomia entre público e privado como anti-feminista, elaborando uma exigência ética de constrangimento do pluralismo moral em nome igual dignidade moral de todas as pessoas. Esta exigência de consistência monista entre os planos de relações é, em parte,

liberdade. A resposta rawlsiana pelo argumento da importância da estrutura básica e da justiça de fundo.

108 Nagel, 2005, p. 123.

109 Nagel, 2005, p. 125.

110 Nagel, 2005, p. 119. 
decorrente da ubiquidade do gênero, cujas construções anti-igualitárias perpassam e conectam os diversos planos de relações privadas e públicas, pessoais e políticas etc.

Para a "concepção política" de justiça, diversamente dessas formas de feminismo e de cosmopolitismo,

sovereign states are not merely instruments for realizing the preinstitutional value of justice among human beings. Instead, their existence is precisely what gives the value of justice its application, by putting the fellow citizens of sovereign states into a relation that they do not have with the rest of humanity, an institutional relation which must then be evaluated by the special standards of fairness and equality that fill out the content of justice ${ }^{111}$.

Podemos assumir com Rawls e com Nagel que âmbitos diferentes da vida e convivência humanas devem ser normativamente tratados de modo diverso, de acordo com a natureza das relações humanas e de poder envolvidas e isso é fundamental tanto para respeitarmos a igualdade moral humana - que é axiomática do ponto de vista deste trabalho - quanto o pluralismo moral ${ }^{112}$.

No entanto, se a prioridade máxima assumida é a igualdade moral humana universalmente entendida - e a inviolabilidade individual por ela exigida, talvez os planos de justiça local, doméstica e global não sejam tão estanques quanto pensam Rawls $^{113}$ e Nagel. A opção por entendermos a igualdade moral humana como universal e pensarmos a moralidade política de toda a humanidade segundo o individualismo ético faz com que estes planos se borrem, pois as pessoas podem estar sujeitas a relações de poder que podem se tornar violações de sua igual liberdade não apenas no plano de uma estrutura básica doméstica, mas em todos os planos nos quais existe troca de influências entre as possíveis pessoas morais: entre pessoas de um mesmo país, entre pessoas e seus Estados, entre pessoas e suas associações e comunidades, entre

\footnotetext{
${ }^{111}$ Nagel, 2005, p. 120.

${ }^{112}$ O pluralismo moral que deve ser respeitado cosmopolitamente, na perspectiva deste trabalho, é o "pluralismo moral razoável", isto é, o pluralismo da convivência entre "doutrinas abrangentes do bem razoáveis", que não requerem que o Estado use o seu aparato coercitivo para se imporem sobre as demais, sendo compatíveis com uma "categoria do político", nisso, seguimos ideias desenvolvidas por Rawls (vide, por exemplo, RAWLS, John. O Liberalismo Político. São Paulo, Martins Fontes, 2011).

${ }^{113}$ Rawls afirma explicitamente em $O$ Direito dos Povos que iria contra o espírito liberal exigir dos povos não-liberais que endossem valores liberais de respeito aos direitos individuais, o que o leva a defender um direito internacional dirigido a povos e cujos sujeitos de direito não são indivíduos. Além disso, Rawls afirma que não há uma estrutura básica global que justifique uma "justiça global" (RAWLS, John. O Direito dos Povos. São Paulo, Martins Fontes, 2001).
} 
comunidades, entre associações, entre comunidades e associações, entre Estados, entre pessoas e Estados de outros países. Assim, o respeito à igualdade moral universalmente entendida, mesmo que conceba a possibilidade de que relações diferentes entre pessoas morais diversas possam ter implicações normativas distintas, coloca o axioma da igualdade moral como válido para todas as esferas de relações entre pessoas morais.

Isso leva à prescrição de algum tipo de "direito de saída" que deve ser acessível para as pessoas em todos os tipos de relação em estão situadas, de modo que todas as comunidades e estruturas básicas possam funcionar como associações no sentido de que possam funcionar como grupos nos quais o pertencimento é (hipoteticamente) "voluntário". A ideia é que uma estrutura básica justa seria uma estrutura básica na qual os diversos pertencimentos são, tanto quanto possível, voluntários na medida em que o "direito de saída" é estatalmente assegurado para todos os tipos de relação. Chamarei isto de "direito de saída pleno" "114, por referir-se simultaneamente à justiça local, social e cosmopolita.

Isso faz com que todo tipo de relação entre pessoas morais esteja sujeito a testes de legitimidade frente à igualdade moral e ao pluralismo moral (em uma perspectiva individualista, isto é, em que o pluralismo deve ser respeitado por consideração às pessoas e não às coletividades). Esta é uma forma de "monismo moral" segundo as definições anteriormente descritas, dado que funde "horizontes de justificação" ou os pensa subordinados a um mesmo critério. E é também uma concepção voltada para a reflexão a respeito das relações de poder que podem ameaçar o espaço de inviolabilidade individual que faz parte do próprio conceito rawlsiano de justiça. A inviolabilidade individual impõe um patamar mínimo de igualdade que é dado por um

\footnotetext{
${ }^{114}$ Ao usar o termo "direito de saída", remeto-me à formulação clássica do conceito de "saída" de Albert Hirschman (HIRSCHMAN, Albert. Saída, Voz e Lealdade. Reações ao declínio de firmas, organizações e estados. São Paulo, Perspectiva, 1973). Tenho pensado em um "direito de saída", mas acredito que possa também ser pensado um direito de "voz" e de "lealdade", dado que estes três conceitos podem ser interessantes para pensarmos o significado da igualdade moral em um mundo de pluralismo moral. Superficialmente, podemos dizer que "saída", "voz" e "lealdade" são as três alternativas disponíveis diante de insatisfação com firmas e outras organizações. "Saída" é a opção do consumidor ou membro de organização insatisfeito por abandonar a firma ou organização e substitui-la por outra. "Voz" é a opção de continuar na firma ou organização pronunciando-se a respeito da insatisfação esperando que isso resulte em mudanças. "Lealdade" é a opção de permanecer sem se pronunciar e pode ser devida à falência das opções de "saída" e "voz". A teoria dos direitos humanos sempre lida com a ideia de "direito de saída", mas acredito que há possibilidades interessantes e inexploradas no uso das noções de "voz" e "lealdade". "Voz" poderia ser usada para se pensar a noção rawlsiana de "consulta hierárquica decente" ou para se pensar um direito humano à democracia, por exemplo. "Lealdade" poderia ser utilizada para se pensar a opção feminina por uma vida tradicional e de modéstia.
} 
“direito de saída" em relação a quaisquer tipos de relação de poder, fazendo-se necessário repensarmos a interpretação do conceito de estrutura básica como objeto da justiça e a noção de arbitrariedades morais. Assim, procuramos uma leitura da estrutura básica que realce as instituições sociais que podem coercitivamente violar o axioma da igualdade moral e uma leitura do que é moralmente arbitrário que ilumine o nosso entendimento do que deve ou não ser entendido como parte da estrutura básica.

De acordo com Rawls, algo é arbitrário do ponto de vista moral quando é fruto não do merecimento dos indivíduos, mas dos acasos da distribuição natural de qualidade e contingências sociais. Assim, é moralmente arbitrário que alguém consiga um maior acesso a vantagens sociais porque nasceu em uma determinada classe, etnia, gênero ou com determinadas características físicas ou talentos ${ }^{115}$. Seguindo Rawls, considerarei que não é justo que as perspectivas de êxito dos indivíduos sejam limitadas por arbitrariedades morais e incluirei entre estas tanto o nascimento em um determinado país ou região quanto o gênero ${ }^{116}$ e a sexualidade, o que mistura os planos local, doméstico e global. O "direito de saída" deve ser pensado de modo que nenhuma destas arbitrariedades morais torne o pertencimento das pessoas a coletividades - sejam estas famílias, religiões ou países - menos voluntário, inclusive para as mulheres. Ou seja, devemos pensar os princípios de justiça e o objeto da justiça de modo a expandir o rol de coletividades que funcionam como associações, sendo esta uma tarefa mais "epistêmica" e de justificação do que um dever das pessoas, dado que os pertencimentos das pessoas não são por elas "escolhidos", "externos" ou "instrumentais"117 e sim constitutivos delas.

Assim, o que se propõe é pensar a interpretação do conceito de "estrutura básica" como "objeto primário da justiça" de modo que os "princípios de justiça" acessem todas as possibilidades de "arbitrariedade morais", inclusive o gênero e o país de nascimento.

\footnotetext{
${ }^{115}$ Rawls, 1993, pp. 35-36.

${ }^{116}$ Gênero não aparece como uma arbitrariedade moral em todas as listagens feitas por Rawls, mas é perfeitamente compatível com o espírito de sua obra que consideremos que o próprio Rawls considerava nascer homem ou mulher uma arbitrariedade moral e que ninguém deveria ter suas alternativas de vida condicionadas pelo gênero. As reflexões que Rawls empreende a respeito da família como parte ou não da estrutura básica se relacionam sempre com as desvantagens socialmente construídas para as mulheres.

${ }^{117}$ Estes termos estão entre aspas porque são uma alusão à crítica de Charles Taylor ao entendimento de "cultura" e de "pertencimento" próprios às concepções liberais e individualistas de justiça.
} 


\section{Sobre a relação entre gênero, família, religião, cultura e estrutura básica}

Em Uma Teoria da Justiça de Rawls, a sociedade é uma associação mais ou menos autossuficiente de pessoas que agem e se relacionam de acordo com certas regras que reconhecem como vinculativas e que especificam um sistema de cooperação que visa vantagens mútuas ${ }^{118}$. Nas sociedades assim definidas, há identidade de interesses porque a cooperação social possibilita benefícios que não se alcança individualmente. Há também conflito de interesses, uma vez que a realidade é de escassez moderada e todos (ou a maioria) preferem receber o maior quinhão possível dos benefícios que são acrescidos pela cooperação social. Além disso, nas sociedades complexas, as pessoas estão divididas numa multiplicidade de particularismos quanto às crenças sobre o que seja o bem ou a felicidade e, devido à sua já mencionada igualdade moral, devem poder exercê-las livremente. Rawls chama essa diversidade de "pluralismo moral" e denomina estas situações objetivas e subjetivas de "circunstâncias da justiça"119.

Como vimos, o objeto primário da justiça é a estrutura básica da sociedade, que é a forma como as principais instituições políticas, econômicas e sociais distribuem os benefícios e encargos advindos da cooperação social. As liberdades jurídicas, a concorrência de mercado, a propriedade privada e a família monogâmica são exemplos dessas instituições. Elas definem os direitos, deveres e expectativas de vida de cada um. "A estrutura básica da sociedade é o objeto primário da justiça porque as suas consequências são profundas e estão presentes desde o início" nas várias situações sociais, favorecendo algumas "posições" em detrimento de outras, de maneira a produzir "desigualdades profundas". É a essas desigualdades que "os princípios da justiça devem se aplicar em primeiro lugar, presidindo a escolha das instituições políticas, econômicas e sociais". "A justiça de um modelo de sociedade depende essencialmente da forma como são atribuídos os direitos e deveres fundamentais, bem como das oportunidades econômicas e condições sociais nos diferentes setores da sociedade" 120 . Deve haver uma concepção de justiça sobre a estrutura básica da sociedade, porque ela é coercitiva numa associação fechada que não é voluntária - isto

\footnotetext{
${ }^{118}$ Rawls, 1993, p. 28.

${ }^{119}$ Rawls, 1993, p. 115.

${ }^{120}$ Rawls, 1993, p. 30.
} 
é, os indivíduos não escolhem estar ou não inseridos nessa estrutura, entram ao nascer e têm um alto ônus de saída, pois foi nela que se socializaram e que têm seus grupos de convivência.

O conceito de estrutura básica possui muitos componentes e não há uma única interpretação possível sobre o que é englobado nele ou sobre suas implicações normativas. O próprio John Rawls é ambíguo a respeito de quais instituições fazem ou não parte da estrutura básica. Em relação ao problema da justiça de gênero, é particularmente importante a ambiguidade rawlsiana sobre a inclusão ou não da família entre as instituições que compõem a estrutura básica, em alguns momentos ela é citada e em outros não.

Se, ao interpretarmos o conceito de estrutura básica, realçarmos que ela é um arranjo que distribui benefícios e encargos da cooperação; que através dessa cooperação se produz benefícios que não seriam alcançadas por indivíduos e pessoas morais isolados; que os arranjos de cooperação são coercitivos e inescapáveis e que possuem consequências profundas sobre as expectativas de vida dos indivíduos, a família é, sem dúvida, pertencente à estrutura básica. Esta ênfase interpretativa vai de encontro aos motivos que fazem com que as feministas - desde o trabalho seminal de Susan Okin ${ }^{121}$ intitulado Justice, Gender, and the Family - considerem que a família faz parte da estrutura básica. Conforme argumentam quase todas as feministas, as relações de poder e a divisão do trabalho intrafamiliar afetam as relações de poder e o acesso a direitos no mundo do trabalho e na política e produzem e perpetuam desigualdade e injustiça de gênero e que isto ocorre em todos os países.

Perceber a família como parte da estrutura básica é um passo importante para se manter a coerência com o individualismo ético, pois, ao contrário do que parte da teoria política $^{122}$ pensou, não há identidade de interesses completa entre os diversos membros da família e há conflitos e relações de poder entre eles, como fica evidenciado pelo

\footnotetext{
${ }^{121}$ OKIN, Susan Moller. Justice, Gender, and the Family. Nova York, Basic Book, 1989.

122 Isso aparece, por exemplo, em Rousseau, Hume, Michael Walzer, Michael Sandel, Allan Bloom, Gary Becker, Manser \& Brown e Lundberg \& Pollak. Diversas feministas dedicaram partes substanciais de suas obras a defender que a família não deve ser considerada como uma esfera de afeto mútuo para além da necessidade da virtude da justiça, vide, por exemplo, Susan Okin, Martha Nussbaum e Carole Pateman; Amartya Sen também defende esta ideia em inúmeros trabalhos, vários deles dedicados à qualidade de vida e à desigualdade em geral e não ao problema específico do gênero. $O$ sempre repetido slogan "o pessoal é político" é uma síntese desta crítica feminista.
} 
problema da divisão sexual do trabalho doméstico e pela distribuição de recursos intrafamiliar e o modo como necessidades alimentares, de saúde e educação de meninos e meninas são pensadas como distintas em qualidade e importância. Em casos extremos, isso se reflete no problema das "mulheres faltantes" na Ásia e no norte da África ${ }^{123}$, conforme mencionado Sen ${ }^{124}$. Amartya $\operatorname{Sen}^{125}$ e Susan Okin ${ }^{126}$, entre outros, detiveramse repetidamente sobre este problema. Para o primeiro, as concepções sociais e culturais sobre os papéis femininos fazem com que uma mesma quantidade de direitos formais signifiquem diferentes possibilidades de exercício de liberdade por parte de homens e mulheres. E, nas palavras de Okin

many social 'goods,' such as time for paid work or for leisure, physical security, and access to financial resources, typically are unevenly distributed within families. Though many may be 'better than just, ${ }^{127}$ at least most of the time, contemporary gender-structured families are not just. But they need to be just. They cannot rely upon the spirit of generosity - though they can still aspire to it - because the life chances of millions of women and children are at stake. They need to be just, too, if they are to be the first schools of moral development, the places where we first learn to develop a sense of justice. And they need to be just if we are even to begin to approach the equality of opportunity that our country claim as one of its basic ideals. ${ }^{128}$

\footnotetext{
${ }^{123}$ Em condições de qualidade de vida normais (europeias e norte-americanas, com acesso a nutrição adequada, moradia, saúde e educação), as mulheres possuem expectativa de vida mais longa do que a dos homens, fenômeno que é atribuído a causas biológicas e que explicaria as razões entre mulheres e homens europeias e norte-americana. No entanto, apesar disto que Amartya Sen chama "preponderância feminina", em várias regiões do mundo a expectativa de vida feminina é menor do que a masculina e há número inferior de mulheres no total da população. Segundo Sen, em Desenvolvimento como Liberdade, "As baixas razões entre mulheres e homens em países da Ásia e da África setentrional indicam a influência de fatores sociais. Calcula-se facilmente que, se esses países apresentassem a mesma razão entre mulheres e homens encontrada na Europa e nos Estados Unidos, haveria milhões de mulheres a mais naquelas regiões (dado o número de homens). Só na China o número de 'mulheres faltantes' calculado com base na razão europeia ou americana, seria superior a 50 milhões e, nessa base, para esses países considerados em conjunto, muito mais do que 100 milhões de mulheres podem ser consideradas 'faltantes'” (SEN, Amartya. Desenvolvimento como Liberdade. São Paulo, Companhia das Letras, 2000, p. 129). O problema das "mulheres faltantes" é mais uma evidência do modo como o acesso a direitos civis, políticos e socioeconômicos é indissociável e de como desigualdades consideradas menos letais podem levar a fragilização do direito de saída feminino e à violação da integridade física e do direito à vida.

${ }^{124}$ Sen, 2000, p. 35, pp. 129-130, p. 132, p. 222. Sen, 1995, p. 259. Muitos estudos de pesquisadores do World Institute for Development Economics Research of the United Nations University (UNU-WIDER) dedicam reflexões e proposições de políticas voltadas para este problema (http://www.wider.unu.edu/). ${ }^{125}$ Sen, 1995, pp. 260-261.

${ }^{126}$ OKIN, Susan. Justice, Gender, and the Family. Nova York, Basic Books, 1989, pp. 25-40.

${ }^{127}$ Alusão a autores que dizem que as famílias não precisam ser justas porque possuem qualidades morais superiores à justiça, como generosidade, altruísmo e afeto.

${ }^{128}$ Okin, 1989, p. 31.
} 
A esfera familiar (e privada) é profundamente governada por moralidades compartilhadas e entendimentos culturais a respeito dos papéis e das relações de gênero. Colocá-la como objeto da justiça por ser parte da estrutura básica da sociedade obriga a repensar várias questões centrais para as teorias normativas da justiça.

As concepções sociais "do dever" ser das relações e papéis de gênero expressas nas relações intrafamiliares colocam a família no âmbito das tradições e crenças culturais compartilhadas que fazem parte de identidades coletivas e não apenas de identidades individuais, o que nos leva (1) à controvérsia entre direitos individuais e coletivos e (2) ao papel das moralidades compartilhadas na justificação dos princípios de justiça e direitos humanos.

Mas, apesar das famílias serem o principal componente "privado" e sociocultural do gênero que Susan Okin reivindica ser incluso de maneira indubitável na estrutura básica da sociedade, não é ela a única instituição social "privada" e sociocultural que constrói o gênero. Como vimos, a ubiquidade do gênero faz com que suas relações ultrapassem todas as fronteiras entre esferas e instituições da vida social e sejam formadas através destas esferas e instituições e formadoras destas mesmas esferas e instituições. Assim, não apenas a família, mas gênero como um todo deve estar refletido em uma interpretação adequadamente feminista da estrutura básica como objeto da justiça. Isso exige que a "família" não seja o único âmbito de "justiça local" acessado pela justiça, mas também as igrejas, associações e comunidades culturais que, em Is Multiculturalism Bad For Women? e em sua crítica a $O$ Liberalismo Político ${ }^{129}$, são defendidas pela própria Susan Okin como loci de construção e perpetuação do gênero como poder e "institucionalização da diferença sexual". Nenhuma delas deve ser isenta de justiça no sentido mínimo de que nenhuma delas deve violar liberdades básicas de nenhum de seus membros, nem mesmo das mulheres, por mais que, dentro do "pluralismo moral razoável”, normas de modéstia feminina sejam liberalmente legítimas sempre que houver "direito de saída" dentro destes grupos e devam ser toleradas ${ }^{130}$ sempre que as mulheres demonstrarem que não querem se desviar delas. E estas outras instâncias do "privado" - igreja, associações e comunidades culturais - permeiam e

\footnotetext{
${ }^{129}$ Vide OKIN, Susan Moller. "Justice and Gender: An unfinished debate." Fordham Law Review. Symposium Rawls and the Law. Vol. LXXII, Number 5, April 2004, 1537-1567.

${ }_{130}$ Ao menos dentro da perspectiva do feminismo liberal, o que faz com que diversas variantes do feminismo radical, como o Catherine MacKinnon e Andrea Dworkin considerem o liberalismo antifeminista.
} 
constroem a família, afinal, esta é toda conforme construções sociais do dever ser dos papéis de gênero e estes são grandemente determinados pela religião e pela cultura, juntamente com a família. A ubiquidade do gênero é também uma indissociabilidade de todas as esferas e instituições em relação a ele e, portanto, também entre si.

Como as famílias, igrejas, associações e comunidades culturais são loci de relações constituídas e constitutivas de valores culturais frequentemente anti-igualitários endossados por sujeitos de direito, também nos obrigam a refletir sobre a validade normativa de se pensar métricas objetivistas (independentes das crenças e preferências expressas pelos sujeitos de direito) e subjetivistas (oriundas de crenças e preferências expressas pelos sujeitos de direito) na fundamentação e justificação normativas.

Ao mesmo tempo, a percepção da família, da igreja e das associações e comunidades culturais como loci de distribuição não-igualitária de direitos e liberdades nos leva a questionar a divisão analítica e normativa entre as esferas pública e privada ao se pensar o objeto dos princípios de justiça, como vimos anteriormente.

Soma-se a isso o fato de que a distribuição de ônus e benefícios intrafamiliar diminui as liberdades sociais e econômicas de mulheres e crianças frente às dos homens e impede o pleno exercício de direitos civis e políticos importantes para que as mulheres possam sair de situações familiares desconfortáveis, violadoras de direitos ou opressivas. O que traz a questão da relação entre justiça distributiva e justiça civil e política.

Como todos estes problemas oriundos da desigualdade de gênero e expressos nas relações familiares existem em todos os países e estamos tomando como normativamente válido que as pessoas são fins em si mesmas em todos os países do mundo, isso também requer respostas a respeito (1) da lista de direitos normativamente defensável pelo cosmopolitismo moral, (2) do que é passível de ser exigido de qualquer Estado existente e (3) de qual o escopo da justiça global normativamente mais defensável. 


\subsection{Instituições, informais práticas sociais e estrutura básica}

Passemos ao problema da relação entre família, religião, práticas culturais, usos sociais, costumes e convenções dentro daquilo que é parte do debate sobre a estrutura básica. Os autores que utilizaremos a seguir lidam mais diretamente com o problema da relação entre as condutas e escolhas individuais maximizadoras no mercado e a justiça distributiva. Procuraremos ver este debate pelas lentes do problema da desigualdade de gênero e suas consequências para as liberdades básicas das mulheres.

Se o aspecto da coerção e dos efeitos profundos e inescapáveis sobre as vidas dos indivíduos são centrais para a definição de estrutura básica, que é o objeto da justiça, não apenas a família, mas a religião e também instituições informais ${ }^{131}$ culturais podem ser vistas como pertencentes à estrutura básica, dado que a cultura é coercitiva, anterior e externa aos indivíduos. Se interpretarmos que a estrutura básica é composta por instituições coercitivas formais e informais, o objeto da justiça distributiva precisaria ser entendido de modo a compreender não apenas instituições políticas e legais formais, mas também padrões de escolhas individuais que não são constrangidas pelo Estado. Esta é uma das teses centrais de Gerald Cohen a respeito da ideia de estrutura básica como objeto da justiça e que ele considera uma "radicalização do slogan feminista" segundo o qual "o pessoal é político"132. E esta "radicalização do slogan o pessoal é político", por sua vez, é fundamental para a "radicalização feminista" do liberalismo rawlsiano proposta por Susan Okin e que intendemos levar às suas últimas consequências nesta tese, através de uma "radicalização feminista cosmopolita".

\subsubsection{O argumento de Gerald Cohen}

Passemos ao argumento de Gerald Cohen a respeito da estrutura básica e a justiça distributiva.

\footnotetext{
${ }^{131}$ Aqui, o adjetivo "informal" significa apenas aquilo que não é determinado ou imposto legalmente.

${ }^{132}$ COHEN, G. A. "Where the Action Is: on the site of distributive justice." Philosophy and Public Affairs, Vol. 26, No. 1, 1997, pp. 3-30.
} 
O princípio da diferença incluso no segundo princípio da justiça de Rawls afirma que "as desigualdades socioeconômicas devem se estabelecer para o maior benefício

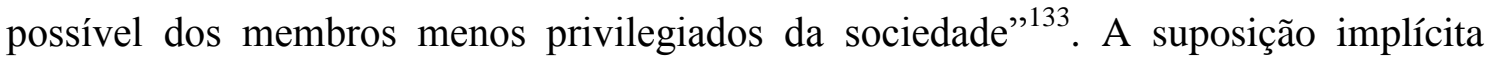
neste estabelecimento de desigualdades distributivas justas é a de que são necessários incentivos para que as pessoas com determinados talentos, profissões e posições sociais se dediquem intensamente a atividades produtivas para que os benefícios socialmente construídos sejam aumentados de modo a beneficiar ao máximo as piores posições sociais, redundando em mais qualidade de vida e liberdades efetivas para estas piores posições do que as possíveis em um sistema de igualdade distributiva estrita.

Há diversas controvérsias sobre a interpretação de quanta desigualdade o princípio da diferença permite. Em uma interpretação estrita, as desigualdades que beneficiam os mais "talentosos" - aqueles cujos talentos recebem as maiores recompensas - seriam justificadas apenas quando a desigualdade é necessária para que os mais talentosos produzam de modo a melhorar a situação das piores posições, sendo esta necessidade independente das intenções dos mais talentosos. Em uma interpretação frouxa, estas desigualdades que privilegiam os mais talentosos são necessárias porque exigidas pelos mais talentosos, que, de outra maneira, não seriam tão produtivos e não colaborariam socialmente para elevar o quinhão distributivo das piores posições, assim, a "necessidade" advém de preferências dos agentes e não da especificidade dos trabalhos que exercem ${ }^{134}$.

Segundo Gerald Cohen, em sua Tanner Lecture de 1992, intitulada Incentives, Inequality, and Community, o argumento dos incentivos em sua interpretação frouxa, não é aceitável frente à "comunidade de justificação" quando formulado na primeira pessoa pelos mais talentosos. A igualdade exigiria de todos um ethos ${ }^{135}$ igualitário a partir do qual pessoas cujos talentos são mais valorizados socialmente não exigiriam recompensas extras e anti-igualitárias para serem produtivas e melhorarem o quinhão distributivo dos pior posicionados ${ }^{136}$. O incentivo à produtividade dos mais talentosos

\footnotetext{
${ }^{133}$ Rawls, 2011, p. 6.

${ }^{134}$ COHEN, Gerald. "Incentives, Inequality, and Community". 1992. Disponível em http://tannerlectures.utah.edu/lectures/documents/cohen92.pdf

${ }^{135}$ Definição de ethos de G. A. Cohen: "The ethos of a society is the set of sentiments and atitutes in virtue of which its normal practice, and informal pressures, are what they are" (Cohen, 1997, p. 28).

${ }^{136}$ Cohen, Gerald, 1992.
} 
contido no princípio da diferença seria incoerente com a própria intenção igualitária do segundo princípio da justiça rawlsiana.

Esta crítica à possibilidade da admissão da interpretação frouxa do princípio da diferença e aos incentivos anti-igualitários nele contidos levará, posteriormente, a uma crítica ao entendimento do objeto da justiça como restrito a instituições coercitivas legais.

Dado que, para G. A. Cohen, (1) as desigualdades relevantes do ponto de vista da justiça - desigualdades distributivas dos benefícios e encargos oriundos da vida social - não são construídas apenas pelas escolhas que as pessoas fazem dentro dos parâmetros regulados pelas estruturas coercitivas legais, mas também por escolhas que fogem ao âmbito do que é legalmente regido, isto é, por escolhas que não são prescritas e nem proibidas pelas regras legais e que (2) este autor tende a interpretar que, para Rawls, a estrutura básica da sociedade inclui apenas instituições coercitivas estatais e legais, temos um problema de interpretação adequada do "objeto da justiça"137. Assim, em seu Where the Action Is: on the site of distributive justice, G. A. Cohen propõe o seguinte questionamento:

Why should we care so disproportionately about the coercive basic structure, when the major reason for caring about it, its impact on people's lives, is also a reason for caring about informal structure and patterns of choice? To the extent that we care about coercive structure because it is fateful with regard to benefits and burdens, we must care equally about the ethi that sustain gender inequality, and inegalitarian incentives. And the similarity of our reasons for caring about these matters will make it lame to say: ah, but only the caring about coercive structure is a caring about justice, in a certain distinguishable sense. That thought is, I submit, incapable of coherent elaboration. ${ }^{138}$

O próprio Gerald Cohen reconhece - da mesma maneira que Susan Okin ao tratar da ambiguidade da inclusão da família na estrutura básica - que Rawls não exclui simplesmente as instituições e estruturas coercitivas não estatais da estrutura básica e que há uma ambiguidade sobre se a estrutura básica inclui convenções, usos, expectativas sociais e padrões de escolhas pessoais não legalmente coercitivos, que podem estar implícitos na expressão "major social institutions" que é parte do conceito

\footnotetext{
${ }^{137}$ Cohen, 1997, pp. 3-4.

${ }^{138}$ Cohen, 1997, p. 23.
} 
de estrutura básica e entre os quais estão a família e o mercado ${ }^{139}$. Os efeitos destas "major social institutions" são tão profundos quando o das instituições coercitivas estatais, mesmo constituindo padrões de desigualdade que emergem das próprias escolhas, ações e comportamentos pessoais. É "justo" colocar estas escolhas sob o âmbito da justiça? Se sim, volta a afirmação de que um ethos igualitário é uma exigência de justiça, assim como a condenação normativa do comportamento maximizador próprio do mercado e do comportamento sexista dentro das famílias e, acrescento, dentro das comunidades religiosas e culturais.

Gerald Cohen supõe que Rawls colocaria as escolhas pessoais fora do escopo da justiça através de uma "basic structure objection" que afirmaria que apenas instituições e escolhas institucionais são objeto da justiça ${ }^{140}$. E refuta esta objeção imaginada afirmando que ela não é coerente com a ideia rawlsiana de justiça e propõe que "the principles of justice apply not only to coercive rules but also to the pattern in people's (legally) unconstrained choices"141 e que "it is essential to apply principles of justice to dominant patterns in social behavior." 142

O argumento geral desta tese concorda com a afirmação de G. A. Cohen segundo a qual padrões dominantes de comportamento social devem ser "objeto da justiça”. No entanto, faz-se necessário abrir um parênteses de "justiça a Rawls”, pois, apesar da ideia desta "basic structure objection" ser compatível com o sistema rawlsiano de justiça, não é claro que o próprio Rawls endossaria esta resposta, conforme fica patente (1) pela própria ambiguidade da inclusão ou não da família dentro das instituições da estrutura básica, (2) pelo fato de que regras jurídicas coercitivas no sentido de Cohen e que se dirigem diretamente aos comportamentos pessoais fazem parte da estrutura básica, como por exemplo leis que proíbem que um cidadão viole as liberdades civis de outros e (3) pela afirmação de Rawls de que se a esfera privada for considerada uma esfera isenta de justiça, ela não existe ${ }^{143}$.

\footnotetext{
${ }^{139}$ Cohen, 1997, p. 11.

${ }^{140}$ Cohen, 1997, p. 12.

${ }^{141}$ Cohen, 1997, p. 25.

142 Cohen, 1997, p. 26.

${ }^{143}$ Ideia apresentada explicitamente em "A ideia de razão pública revista".
} 
Além disso, conforme lembra Samuel Scheffler" ${ }^{144}$ a respeito da "basic structure objection” formulada por G. Cohen, a divisão do trabalho proposta por Rawls (1) nunca incluiu a afirmação de que é legítimo que as pessoas ajam apenas conforme seu autointeresse econômico; (2) nem a afirmação de que as pessoas não carregam nenhuma obrigação de levar em conta os princípios de justiça; (3) e a esta divisão do trabalho se dirigia a teorias como o utilitarismo, que considera que um único princípio de maximização das utilidades é suficiente para regular as instituições sociais e a conduta individual $^{145}$.

Independentemente das respostas hipotéticas de Rawls à crítica de Gerald Cohen ao foco na estrutura básica, a coercividade legal não é a única que afeta a vida e as escolhas dos indivíduos e não resulta em injustiças. Conforme afirma Frank Michelman, poderes públicos legais e estatais não são os únicos que incidem sobre liberdades ${ }^{146} \mathrm{e}$ não podemos simplesmente pressupor, sem justificações, que as subversões da liberdade cometidas pelo poder público são mais perigosas para a liberdade e igual proteção pela lei do que as subversões cometidas pelos poderes e interesses privados ${ }^{147}$. Ainda que os "poderes estatais", por seu caráter soberano, requeiram justificação especial frente a indivíduos concebidos como livres e iguais. Nas palavras de Samuel Scheffler, "the use of the coercive power of the state to impose unjust social arrangements is a great evil, greatly to be feared. However unjust or otherwise unacceptable a social arrangement may be, the coercive enforcement of such arrangement is even worse." ${ }^{148}$ Isso é reconhecido pelo próprio Gerald Cohen quando este pondera que "estruturas não-

\footnotetext{
${ }^{144}$ Samuel Scheffler em SCHEFFLER, Samuel. "Is the Basic Structure Basic?" In SPINOVICH (org.). The Egalitarian Conscience: essays in honour of G. A. Cohen. Oxford, Oxford University Press, 2006, pp. 102129. Artigo disponível em http://www.princeton.edu/csdp/events/Scheffler111105/Scheffler111105.pdf (a numeração das páginas nas citações presentes nesta tese estão conforme o arquivo disponível neste link).

${ }^{145}$ Scheffler, 2006, pp. 18-19.

${ }^{146}$ MICHELMAN, Frank. "Conceptions of Democracy in American Constitutional Argument: The Case of Pornography Regulation." Tennessee Law Review Vol. 56 (1988-1989), pp. 291-320.

${ }^{147}$ Michelman, 1988-1989, p. 309. Michelman argumenta neste sentido ao pensar a regulação da liberdade de expressão pela Suprema Corte dos Estados Unidos da América e chama a pressuposição de que os poderes públicos são os mais ameaçadores da liberdade individual de "the public-power/privatepower distinction". Distinção que afirma estar implícita na interpretação liberal da Primeira Emenda e na defesa liberal da liberdade de expressão dos pornógrafos, defesa esta que negligencia o silenciamento das mulheres construído pela expressão não regulada de conteúdos discriminadores que constroem a deslegitimação social das mulheres (e de diversas outras minorias políticas, como minorias raciais e sexuais). Penso que este argumento serve para pensarmos toda reflexão normativa liberal baseada na dicotomia público/privado e na pressuposição irrefletida de que a cultura não é parte da construção das desigualdades relevantes da perspectiva da justiça.

${ }^{148}$ Scheffler, 2006, p. 37.
} 
coercitivas" e "práticas não-coercitivas"149 são áreas em que as pessoas possuem escolhas que possibilitam mudanças incrementais; ao passo que "estruturas coercitivas" 150 são mais insuladas e independentes das escolhas cotidianas das pessoas $^{151}$.

Estabelecida a importância do que não é estatal e jurídico para a construção social da desigualdade e da não-liberdade e estabelecido o caráter especial da justificação devida às instituições estatais, passemos a uma das principais refutações ao argumento de Gerald Cohen.

\subsubsection{Instituições, publicidade e estrutura básica}

Consideraremos aqui duas respostas contra a inclusão de um ethos igualitário como objeto da justiça e exigência da justiça pretendida por Gerald Cohen: a de Andrew Williams ${ }^{152}$ e a de Álvaro de Vita ${ }^{153}$.

As respostas de ambos são centradas no conceito de "instituições" incluso na definição de estrutura básica como composta pelas "principais instituições políticas, econômicas e sociais". Rawls formula um conceito de "instituições" que requer uma condição de publicidade que não é atendida pela noção de ethos igualitário de G. A. Cohen e nem pelas condutas e comportamentos pessoais dentro das instituições que não são prescritas por elas, isto é, as táticas e estratégias maximizadoras das pessoas que atuam dentro das regras do jogo, assim como seus hábitos e atitudes culturalmente orientados, entre os quais estão os padrões de comportamento orientados por gênero e a vida intrafamiliar.

\footnotetext{
149 Em que "não coercitivo" significa "não estatal" e "não-legalmente determinado".

150 Em que "coercitivas" significa "estatais" e "legais".

${ }^{151}$ Scheffler, 2006, pp. 37-38.

152 WILLIAMS, Andrew. "Incentives, Inequality, and Publicity." Philosophy \& Public Affairs 27, no. 3, 1998, pp. 225-247.

${ }^{153}$ VITA, Álvaro de. O Liberalismo Igualitário. Sociedade democrática e justiça internacional. São Paulo, Martins Fontes, 2008, pp. 61-90.
} 
Vejamos esta definição de "insitutições" e as condições de "publicidade" formuladas por Rawls em Uma Teoria da Justiça, através de uma citação de Rawls retirada de Vita,

Por instituição, entendo um sistema público de normas que define cargos e funções com seus direitos e deveres, poderes e imunidades etc. Essas normas especificam que certas formas de ação são permissíveis e outras, proibidas; e estipulam certas penalidades e defesas, e assim por diante, quando ocorrem transgressões. Como exemplos de instituições ou, de forma mais geral, de práticas sociais, podemos citar jogos e ritos, julgamentos e parlamentos, mercados e sistemas de propriedades.

(...) A instituição existe em determinado momento e local quando os atos especificados por ela são regularmente realizados segundo um entendimento público de que se deve obedecer ao sistema de normas que a define. Assim, as instituições parlamentares são definidas por determinado sistema de normas (ou por uma família de tais sistemas, para permitir variações). Essas normas enumeram certas formas de ação que vão da realização de sessões do parlamento, passando pela votação de projetos de lei, ao levantamento de questões de ordem. Organizam-se vários tipos de normas gerais em um sistema coerente.

(...) Ao afirmar que a instituição, e, portanto, a estrutura básica da sociedade, é um sistema público de normas, quero dizer que todos nela envolvidos sabem o que saberiam se tais normas e sua participação nas atividades que essas normas definem fossem resultantes de um acordo. A pessoa que participa da instituição sabe o que as normas exigem dela e das outras. Também sabem que as outras pessoas sabem disso e sabem que ela sabe disso, e assim por diante. Decerto essa estipulação nem sempre é cumprida no caso das instituições existentes, mas é um pressuposto simplificador razoável. Os princípios de justiça devem aplicar-se a arranjos sociais entendidos como públicos nesse sentido. Quando as normas de determinado setor de uma instituição só são conhecidas por quem a ele pertence, podemos supor que existe um entendimento de que essas pessoas podem criar normas para si mesmas, contato que essas normas se destinem a atingir fins amplamente aceitos e que outros não sejam prejudicados. A divulgação das normas da instituição garante que aqueles nela envolvidos podem saber que limitações de conduta esperar uns dos outros e quais são os tipos de atividades permissíveis. Há um fundamento comum para a definição das expectativas mútuas ${ }^{154}$.

${ }^{154}$ Rawls, 2008, pp. 66-7, apud Vita, 2008, pp. 77-79 
É esta compreensão de instituições e das condições de publicidade nela inclusas que dão a tônica da resposta de Álvaro de Vita à interpretação de Gerald Cohen sobre o conceito de estrutura básica, que é sintetizada na citação de Vita a seguir

O componente central dessa definição de instituição e de estrutura básica como um "sistema público de normas" não é a coercividade legal, como o contra-argumento de Cohen supõe, e sim a publicidade - isto é, a medida em que a aplicabilidade, as exigências específicas e a obediência a essas normas são passíveis de se converter em "conhecimento comum" de todos os participantes. Essa concepção é complementada pela ideia de que é preciso distinguir entre as "normas constitutivas" de uma instituição, que estão sujeitas ao critério de publicidade, e as estratégias adotadas por indivíduos e grupos que agem procurando tirar proveito das oportunidades que essas normas lhes oferecem para realizar seus próprios interesses. Nas palavras de Rawls, "as estratégias e táticas adotadas pelos indivíduos, essenciais como são à avaliação das instituições, não fazem parte dos sistemas públicos que as definem." 155

A resposta de Andrew Williams vai neste mesmo sentido. Para ele, a definição de instituições e condições de publicidade acima citadas mostram que uma interpretação adequada da noção de estrutura básica em Rawls é uma interpretação em "the structure comprises those actions which realize public rules in a way that exerts profound and

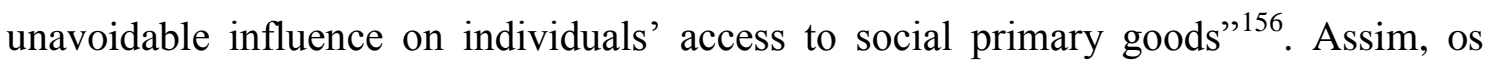
princípios de justiça rawlsianos aplicam-se apenas à seleção de meios institucionais para assegurar liberdades básicas e equidade de oportunidades e é por sua capacidade ou incapacidade de assegurá-las que arranjos institucionais são normativamente avaliados. Estes mesmos princípios não são aplicados às decisões, estratégias e táticas pessoais, pois estas não são e não podem ser conforme as condições de publicidade rawlsiana, tanto por haver auto-interesse razoável, quanto porque o pluralismo moral razoável abre espaço para ações e comportamentos que não são passíveis de julgamento conforme regras públicas ${ }^{157}$. Em suas próprias palavras,

The nonpublic strategies and maxims that individuals employ in making those choices need not be assessed as just or unjust by means of Rawlsian principles. Moreover, amongst such nonintitutional choices is the decision to become a market-maximizer rather than extend egalitarian conviction to ones economic activity. Cohen's

\footnotetext{
${ }^{155}$ Vita, 2008, p. 79.

${ }^{156}$ Williams, 1998, p. 234.

${ }^{157}$ Williams, 1998, p. 234.
} 
opposition to incentives therefore is flawed since it mistakenly assumes those particular choices should be regulated by Rawlsian principles $^{158}$

E, mais fortemente, “Cohen's egalitarian ethos cannot be regarded as realizing public rules" ${ }^{159}$, dado que as decisões, preferências e comportamentos de cada um em suas vidas pessoais estão longe de se enquadrarem na exigência de que ocorram de acordo com regras e princípios que todos aceitam e seguem sabendo que os demais também os aceitam e seguem. Citando apenas um dos exemplos elencados por Williams, a escolha de que profissão seguir não cabe dentro desta demanda de publicidade própria às instituições obedecidas por todos. Dentro disso, para Andrew Williams, o comportamento maximizador, ao não se enquadrar dentro da publicidade própria às instituições em seu entendimento rawlsiano, não é "estrutural" 160 e não pode ser julgado por padrões públicos ${ }^{161}$; paralelamente e pelo mesmo motivo, o ethos igualitário não pode ser "institucional"162:

It is highly improbable that Cohen's favored ethos could be represented as an institution embodying public rules or supply what Rawls calls "a common basis for determining mutual expectations." Instead the ethos appears to lie outside the basic structure. Assuming Rawls's principles apply only to that structure, they do not require any commitment to uphold the ethos $^{163}$.

Há diversas questões a serem analisadas a respeito das respostas de William Andrews e de Álvaro de Vita a Gerald Cohen.

A primeira delas é que do ponto de vista do gênero - que é universalmente antiigualitário através de inúmeros particularismos culturais e morais - e do cosmopolitismo moral - o universalismo moral e o individualismo ético em sua expressão máxima - a descontinuidade entre princípios e regras institucionais públicos e as motivações das pessoas é uma exigência normativa de tolerância fundamental, pois

\footnotetext{
${ }^{158}$ Williams, 1998, p. 234.

${ }^{159}$ Williams, 1998, p. 235.

${ }^{160}$ Williams, 1998, p. 235.

${ }^{161}$ Williams, 1998, p. 240.

162 Williams, 1998, p. 238.

${ }^{163}$ Williams, 1998, p. 241.
} 
colocar gênero e o mundo dentro do escopo da justiça e sob o axioma da igualdade moral humana é fundir os horizontes de justificação normativa na junção do "pessoal é político" com o "mundial é político". Podemos afirmar que se trata do "monismo moral" do axioma da igualdade humana fundamental como princípio que deve reger todos os planos de relações efetivas e potenciais entre todas as pessoas morais concebíveis. Dentro deste monismo, conceber a descontinuidade de motivação moral entre o que é "institucional formal" - estatal e legal - e o que é pessoal é condição para o respeito ao pluralismo moral razoável. Não seria liberal negligenciar a importância ética desta descontinuidade. Conforme afirma Vita, "não é em geral nem desejável nem verdadeiro que seja sempre preciso haver uma coerência perfeita entre os objetivos institucionais e as escolhas e as estratégias adotadas pro aqueles que agem sob o arranjo institucional em questão"164. Assim, anunciando um argumento que será desenvolvido adiante, podemos dizer que, mesmo defendendo uma interpretação do conceito de "estrutura básica como objeto da justiça" em que esta é expandida para além das instituições formais, faz parte da tolerância e justiça liberais que os "meios para a justiça" sejam instituições estatais que sigam as condições de publicidade elencadas no conceito de instituições de Rawls.

Mas, por outro lado, quando Williams e Vita afirmam que é parte da estrutura básica apenas aquilo que atende às especificações de publicidade do conceito de instituições de Rawls, não estão exatamente refutando o argumento de Gerald Cohen, afinal, Williams e Vita estão afirmando justamente que é parte da estrutura básica apenas aquilo que Gerald Cohen chamou de "coercive institutions". De certa forma, Vita e Williams estão formulando em seus próprios termos a "basic structure objection" imaginada por Gerald Cohen, segundo a qual

the difference principle is, by stipulation and design, a principle that applies only to social institutions (to those, in particular, which compose the basic structure of society), and, therefore, not one that applies to the choices, such as those of self-seeking high fliers, that people make within such institutions ${ }^{165}$

Do ponto de vista desta tese, esta objeção é importante justamente por estabelecer a descontinuidade de motivações morais entre pessoas e instituições formais

\footnotetext{
${ }^{164}$ Vita, 2008, p. 71.

${ }^{165}$ Cohen, 1997, p. 5.
} 
que é necessário ao respeito ao pluralismo moral razoável. Assim, esta resposta atende a uma exigência de tolerância liberal, mas não refuta a importância das instituições informais para a desigualdade e violações de liberdade que são informalmente construídas, reproduzidas e perpetuadas, que é essencial do ponto de vista das preocupações feministas com os aspectos coercitivos da construção social do gênero.

\subsubsection{Estrutura básica, formação de necessidades e justiça de fundo}

Um segundo ponto a ser discutido acerca do argumento de Vita e Williams a respeito da publicidade é que a centralidade da "publicidade" das instituições é apenas um aspecto da definição rawlsiana de estrutura básica.

Em sua discussão a respeito da estrutura básica como objeto da justiça rawlsiana, Samuel Scheffler elenca três motivos para esta escolha apresentados pelo próprio Rawls $^{166}$.

O primeiro deles, já mencionado diversas vezes nesta tese, é que os efeitos da estrutura básica da sociedade sobre as possibilidades de vida são profundos e inescapáveis, o que uma pessoa pode alcançar depende de sua posição na estrutura básica $^{167}$.

O segundo é que a estrutura básica molda as necessidades, aspirações e preferências dos cidadãos de um arranjo institucional ${ }^{168}$. Ou seja, a estrutura básica não é apenas um mecanismo para atendê-las e satisfazê-las, mas um modo de criá-las e incentivá-las. Isso aumenta a importância da escolha de arranjos institucionais ser guiada por razões morais. E nos leva à afirmação de que, se a distribuição de aspirações, interesses e preferências é moldada pela estrutura básica tanto quando o status quo

\footnotetext{
${ }^{166}$ Scheffler, 2006.

${ }^{167}$ Scheffler, 2006, pp. 4-5.

${ }^{168}$ Este ponto também é trabalhado por Thomas Pogge. Vide POGGE, Thomas. "A Critique of the Capability Approach". In BRIGHOUSE, Harry \& Ingrid Robeyns (orgs.). Measuring Justice. Primary goods and Capabilities. Cambridge, Cambridge University Press, 2010, pp. 17-60. E também POGGE, Thomas. "Can the Capability Approach Be Justified?" Disponível em http://philosophyfaculty.ucsd.edu/faculty/rarneson/courses/pogge1capability.pdf, acessado em janeiro de 2011.
} 
distributivo, nenhum dos dois possui autoridade normativa ${ }^{169}$. Scheffler tece estas considerações citando o próprio Rawls,

"A theory of justice must take into account how the aims and aspirations of people are formed" (PL, p. 269), and it cannot remain "at the mercy, so to speak, of existing wants and desires" (TJ, p. 261/231 rev.). It must instead consider how "the basic structure shapes the way the social system produces and reproduces over time a certain form of culture shared by persons with a certain conception of their good" (PL, p. 269). Just institutions must be designed so as "to foster the virtue of justice and discourage desires and aspirations incompatible with it" (TJ, 261/231. Rev) $)^{170}$

Por fim, o terceiro motivo elencado por Scheffler é que a justiça das transações entre indivíduos não é dada apenas pela interação entre eles, mas pelas condições de fundo [background conditions]. Transações particulares só são justas quando as condições de fundo são justas e indivíduos não são capazes de preservar condições de fundo justas independentemente delas. Não seria factível responsabilizar os indivíduos por estas condições de fundo. As regras que se aplicam sobre indivíduos devem ser simples, diretas e públicas para funcionarem, pois as pessoas não são capazes de calcular as consequências de cada uma de suas escolhas e ações sobre as condições de fundo e não seria razoável - e, acrescento eu, não seria justo e tolerante - exigir esta capacidade dos indivíduos ${ }^{171}$. Esta tarefa cabe às instituições que fazem a própria estrutura básica. A menos que a estrutura básica da sociedade seja regulada e ajustada apropriadamente, um processo social inicialmente justo pode cessar de sê-lo, independentemende de quão livres e eticamente corretas sejam as transações particulares vistas em mesmas ${ }^{172}$.

Os três motivos elencados por Samuel Scheffler - coerção inescapável, formação de preferências, interesses e necessidades e condições de fundo/justiça de fundo - são centrais no argumento de toda a obra rawlsiana e aparecem mais frequentemente do que o conceito de instituições como atrelado ao atendimento de condições de publicidade. Ainda que, diferentemente de Gerald Cohen, para quem

\footnotetext{
${ }^{169}$ Scheffler, 2006, p. 5

${ }^{170}$ Scheffler, 2006, pp. 5-6.

${ }^{171}$ Scheffler, 2006, pp. 2-7.

172 Vide o caso do exemplo de Wilt Chamberlain formulado pro Nozick e reproduzido na nota 107, da p.
} 51. 
Williams claims that my view that the difference principle must apply to economic choices fails the publicity requirement that Rawls says principles must satisfy to qualify as principles of justice, a requirement that Williams defends. I believe, however, that publicity, as Williams (following Rawls) explicates that notion, is demonstrably not a principle of justice, and that the difference-principle-sensitive ethos that I require meets every defensible publicity requirement on justice."173

pareça-me mais acurado considerar que a publicidade é sim um requerimento de justiça por inúmeras razões, entre as quais, seu ideal de tolerância, sua formulação do "princípio liberal de legitimidade" e suas exigências de justificação pública e aceitabilidade universal dentro de condições de razoabilidade. Os princípios de justiça e a "justiça como equidade" devem ser publicamente aceitáveis segundo Rawls. E a "justiça institucional" e descontinuidade entre motivações morais institucionais e pessoais em circunstâncias de pluralismo moral razoável são em si valores publicamente defensáveis em Rawls, no sentido de passarem nos testes de justificação pública como o "princípio liberal de legitimidade” e da razão pública.

Mas esta importância ética da publicidade não apaga nenhum dos motivos enfatizados na interpretação de Samuel Scheffler e são todos motivos que se relacionam com os aspectos coercitivos das instituições informais produtoras de desigualdades e não-liberdades com que se preocupa G. Cohen: (1) como já afirmamos diversas vezes neste trabalho, instituições informais e padrões de escolhas pessoais e comunitárias são profundamente coercitivas e possuem efeitos inescapáveis; (2) instituições informais, expectativas pessoais e sociais, padrões de escolhas pessoas, modos de conduta etc. são formadores das aspirações, interesses e necessidades das pessoas que são socialmente formadas através da própria estrutura básica; (3) instituições informais como expectativas sociais e padrões de comportamento, crenças e escolhas social e culturalmente orientados afetam as "condições de fundo" e interferem sobre as possibilidades das instituições formais coercitivas estatais e legais serem capazes de proporcionar "condições de fundo" e "justiça de fundo" sob as quais as pessoas possam escolher livremente em um ambiente de pluralismo moral sem dificultar a justiça.

${ }^{173}$ Cohen, 2001, p. 213. 
Este último ponto (3), em concomitância com os dois primeiros aponta novamente para a importância de combinarmos uma interpretação ampliada da estrutura básica - que inclua instituições que vão para além do estatal e legal - como "objeto da justiça" com uma concepção de "meio para a justiça" que seja conforme o ideal de "justiça institucional" e que se restrinja a instituições coercitivas que atendam às condições de publicidade do conceito de instituições formulado por Rawls. Esta combinação é necessária à justiça e tolerância em um ambiente de pluralismo moral em que muitas coerções determinadoras das vidas pessoais devem ser respeitadas por serem constitutivas das pessoas e grupos, ainda que devam ser reguladas de modo a permitir direito de saída pleno para as pessoas que não se sintam confortáveis em obedecer expectativas sociais e culturais - no caso deste trabalho, especialmente aquelas relativas a gênero e sexualidade. Assim, a relativização da importância da publicidade num interpretação expandida do conceito de estrutura básica não contradiz, necessariamente, o ideal de justiça institucional e de instituições coercitivas formais como meio para a justiça.

E, como defende Samuel Scheffler, supondo que a estrutura básica deva incluir instituições e práticas não-coercitivas, disso não decorre que a estrutura básica não seja o objeto adequado da justiça - como G. Cohen, Murphy e outros chegam a afirmar - e que não haja distinção entre a estrutura básica expandida e as escolhas e comportamentos individuais que possam ocorrer dentro dela. A estrutura básica continuaria incluindo estruturas coercitivas formais que podem ser distinguidas de condutas individuais e mesmo as instituições informais inclusas na estrutura básica não esgotariam todas as condutas individuais possíveis e legítimas - lembremos do "pessoal que não é político" por não ser coerção inescapável e violadora. Além disso, permaneceriam as boas razões para tratarmos a estrutura básica expandida como objeto da justiça (1) por seus efeitos profundos sobre as vidas das pessoas, (2) pela necessidade da justiça de fundo, (3) pela influência da estrutura básica na construção das preferências e necessidades das pessoas, (4) porque princípios de justiça universalistas e impessoais não são os guias adequados para todos os tipos de decisão individual, (5) porque existem outras normas e valores apropriados para outras áreas da vida, (6) 
porque os princípios de justiça corretos para os indivíduos dependem dos princípios de justiça corretos para a estrutura básica ${ }^{174}$.

\subsubsection{Publicidade, cultura e instituições informais}

Sobre a resposta de Vita e Williams a Cohen, acredito que há ainda duas considerações importantes. A primeira é que o próprio Rawls, ao longo de Uma Teoria da Justiça, não é claro sobre se o aspecto coercividade ou publicidade - conforme a definição de publicidade acima exposta - é o mais importante do conceito. No entanto, parece-me certo que Rawls não pensa apenas na coercividade legal como pensa Cohen, pois não há como afirmar que apenas a coercividade legal preenche os requisitos do conceito de estrutura básica: principais instituições políticas, econômicas e sociais, distribuir encargos e benefícios, favorecer algumas posições em detrimentos de outras, definir expectativas de vida, acarretar consequências profundas, ser inescapável, participarmos dela involuntariamente e produzir desigualdades.

A segunda consideração é que a coercividade das instituições informais também é "um sistema público de normas" no sentido estrito de que "a aplicabilidade, as exigências específicas e a obediência a essas normas são passíveis de se converter em 'conhecimento comum' de todos os participantes". Afinal, se as normas culturais que agem na família e nas demais relações sociais que não são completa e diretamente reguladas por legislação não fossem passíveis de se converterem em conhecimento comum, (1) o entendimento e as expectativas mútuas seriam pouco prováveis e (2) os papéis de gênero, os papéis raciais, as percepções dos talentos e todas as formas de poder simbólico que são atualizadas pelas escolhas individuais fariam menos sentido para seus praticantes. Contra a alegação de que não há possibilidade de conversão em conhecimento comum completo a respeito das normas informais, lembramos que também não há em relação às normas legais.

\footnotetext{
${ }^{174}$ Scheffler, 2006, pp. 39-40.
} 
Tanto a coercividade formal quanto a informal fazem parte de práticas e concepções culturais e são loci de junção entre as esferas pública e privada (tanto nos sentidos mais estritos quanto nos mais amplos destes dois termos). Assim, é próprio da estrutura básica das sociedades incluir relações de poder culturais e privadas e não apenas formas de poder político, econômico e estatal. Como todas estas formas de poder afetam profundamente as possibilidades de vida abertas a cada indivíduo, os princípios de justiça e direitos humanos devem se aplicar a todas elas em todos os países, a fim de que seja respeitada a exigência normativa de que todos os seres humanos são fins em si mesmos e não meios para a perpetuação de moralidades compartilhadas ou quaisquer outras formas de expressão coletiva.

Em suma, tanto a coercividade formal, quanto a coercividade informal, são próprias de todas as sociedades e definem as expectativas e possibilidade de acesso a direitos e oportunidades de todos os indivíduos de todos os países, sendo que o axioma da igualdade moral se aplica a todos os seres humanos. Sendo assim, isso não serve para pensar apenas a justiça e a legitimidade política dos países ocidentais. E a própria inclusão da coercividade social informal na interpretação do conceito de estrutura básica serve para se questionar os próprios argumentos de justificação via "interpretação" e de "moralidade mínima" de Walzer"175 e via "consenso sobreposto global" de Charles Taylor ${ }^{176}$, que são baseados na atribuição moral de valor central às moralidades compartilhadas $^{177}$.

A distinção entre "normas constitutivas da instituição" - que podem ser conhecidas por todos - e estratégias e ações individuais - que são de conhecimento particular - também é possível no caso das relações de dominação e coerção informais, afinal, as escolhas das pessoas nunca são idênticas às normas e aos papéis e as pessoas podem acessar normas e papéis diferentes em uma mesma situação (exatamente como no caso das normas legais, que também são passíveis de escolha e de interpretação ao serem atualizadas pelos que as exercitam).

\footnotetext{
${ }^{175}$ WALZER, Michael. Thick and Thin. Moral argument at home and abroad. Notre Dame: University of Notre Dame Press, 2006. . Interpretation and Social Criticism. Cambridge-Mass.: Harvard University Press, 1993a.

${ }^{176}$ TAYLOR, Charles. "A World Consensus on Human Rights?" In HAYDEN, Patrick (org.). The Philosophy of Human Rights. St. Paul: Paragon House, 2001.

${ }^{177}$ Isso será discutido adiante.
} 
O fato de Rawls pensar a justiça institucional e não a justiça das ações individuais, não implica e não precisa implicar que ela não se relaciona com práticas sociais $^{178}$. O objeto da justiça é a estrutura básica da sociedade, mas os princípios de justiça são aplicados via Estado e aparato legal (o meio para a justiça é institucional), não tendo que ser incorporados nas decisões cotidianas dos indivíduos a não ser que esta seja a concepção de bem que perseguem. Como no caso da separação normativa liberal entre tolerância como virtude institucional legal (impressa nos arranjos políticos) e tolerância como virtude social (praticada pelos atores em suas interações), devemos, em nome do respeito ao pluralismo moral razoável, pensar a justiça como virtude institucional legal (impressa nos arranjos políticos) separada da "justiça como virtude social" (praticada pelos atores em suas interações). Ideais de tolerância e de justiça como virtudes sociais pertencem ao plano das "doutrinas abrangentes de bem" e estão muito distantes da "categoria do político"179, ainda que a "categoria do político" se relacione com elas ao impor limites à maneira como as doutrinas abrangentes podem agir sobre as outras e reivindicar apoio da coerção estatal. E isto impõe como tarefa de reflexão normativa pensar qual "justiça de gênero como virtude institucional" é defensável e reivindicável frente aos Estados de todos os países e nos princípios de justiça global.

A separação entre tolerância e justiça como virtudes institucionais e como virtudes sociais permite respeitarmos o pluralismo moral sem negligenciar o axioma da igualdade moral, permite pensarmos uma concepção "pública" ou "política" de justiça cujo objeto (a estrutura básica da sociedade em uma interpretação expandida) seja capaz de alcançar as desigualdades privada e culturalmente construídas, como é o caso da construção social do gênero e da desigualdade de gênero, que permeia toda a vida social

\footnotetext{
${ }^{178}$ Um melhor entendimento disto será crucial para uma reflexão mais acurada da relação entre as diversas camadas de público e privado e de como estas camadas podem ou não ser acessadas por uma concepção de justiça como virtude institucional formal.

${ }^{179}$ A "categoria do político" é composta por um rol de valores aos quais se chega através do "consenso sobreposto" entre doutrinas abrangentes razoáveis. Estes valores são free-standing no sentindo de que sobrevivem na "categoria do político" independentemente dos demais valores das doutrinas abrangentes de que fazem parte e são compartilhados por todas as demais doutrinas abrangentes razoáveis. Eles compõem o "domínio do político", que é o espaço da justiça do liberalismo político. Estas doutrinas abrangentes "razoáveis" capazes de formular um "consenso sobreposto" são "razoáveis" no sentido de que não exigem o uso do poder coercitivo estatal para se imporem sobre os demais, sendo liberalmente tolerantes e, em conjunto, elas compõem o âmbito do "pluralismo moral razoável". (Vide Rawls, O Liberalismo Político.)
} 
e que é, sobretudo, constitutiva da família e da religião, que são dois loci importantíssimos do pluralismo moral como fato social e como valor normativo.

Acredito que isso deva ser feito dentro da perspectiva do "liberalismo igualitário" porque ele possibilita uma forma de pensar a justiça em que a relação entre (1) direitos civis e políticos e (2) direitos econômicos e sociais, por visar a igualdade equitativa de oportunidades de escolher que concepção de boa vida seguir, traz grandes possibilidades de pensarmos formas de "direito de saída" para as mulheres que, dentro de circunstâncias de pluralismo moral, decidam sair de situações opressivas (lembrando que esta não é uma decisão predominante e que as mulheres que não o fazem possuem o direito de não o fazer).

O "liberalismo igualitário", como explica Álvaro de Vita, designa um leque de teorias normativas tributárias de Rawls ${ }^{180}$, que subscreve muitos de seus pontos de vista, mas não é mera reiteração de posições por ele defendidas, incluindo vários teóricos que pretendem dar continuidade às reflexões normativas dentro do espírito normativo da obra rawlsiana o que, por vezes, inclui "abandonar inteiramente posições explicitamente adotadas por Rawls" ${ }^{\prime 181}$. O cerne desta vertente normativa é que

Para o liberalismo igualitário, não basta, para que cada cidadão disponha das condições que lhe permitem agir a partir de suas próprias concepções sobre o que é valioso na vida, que seja institucionalmente garantida uma esfera de liberdade negativa; ademais, é preciso que os arranjos institucionais básicos da sociedade propiciem a cada cidadão

\footnotetext{
${ }^{180}$ Eu preferiria dizer "tributárias do neo-kantismo de Rawls", pois acredito que a crítica que pretende construir uma teoria da justiça global "mais rawlsiana" do que o Direito dos Povos rawlsiano é uma crítica profundamente kantiana, no que sigo Onora O'Neill, que considera que Rawls entendeu melhor a teoria de Kant sobre a Virtude do que sua teoria sobre o Direito e que, em justiça internacional, "ser mais rawlsiano que Rawls" implicar radicalizar seu neo-kantismo a partir dos conceitos de "imperativo categórico" e "Direito racional" e do construtivismo kantiano (O’Neill, 2003, 2000 e 1988). Mas não o faço porque Vita - de quem tomo os termos liberalismo igualitário, justiça igualitária e justiça rawlsiana emprestado - defende que Rawls é menos neo-kantiano do que afirma, pois não devemos minimizar o forte vínculo entre a Doutrina do Direito e a Doutrina da Virtude de Kant. Este vínculo dá ao Direito racional kantiano um caráter de "doutrina abrangente" do qual Rawls se esforça para se distanciar e que amplia o apelo da teoria de Rawls para aqueles cujas doutrinas abrangentes não endossam interpretações democráticas e/ou repúblicas do ideal kantiano de "liberdade como autonomia". Como não se trata de qual a melhor interpretação de Kant e sim de um debate a respeito de que elementos normativos kantianos realçar na construção de teorias normativas contemporâneas, os argumentos de O’Neill e Vita olham para aspectos diferentes, mas não se contradizem e o que as críticas de ambos ao Direito dos Povos convergem em muitos pontos.

${ }^{181}$ Vita, 2008, pp. 1-2.
} 
os meios efetivos para fazê-lo, incluindo um quinhão equitativo de oportunidades sociais, renda e riqueza. ${ }^{182}$

Isso ocorre porque a justiça rawlsiana, nas palavras de Nagel, é um desenvolvimento do liberalismo que introduziu teoricamente o reconhecimento da importância das

social and economic structures, equally with political and legal institutions, in shaping people's lives and a gradual acceptance of social responsibility for their effects. When the same moral attention was turned on these as had earlier focused on strictly political institutions and uses of political power, the result was an expansion of the liberal social ideal and a broadened conception of justice. Indeed, the use of the terms "just" and "unjust" to characterize not only individual actions and laws but entire societies and social or economic systems is a relatively recent manifestation of this change of outlook. Rawls's liberalism is the fullest realization we have so far of this conception of the justice of a society taken as a whole whereby all institutions that form part of the basic structure of society have to be assessed by a common standard ${ }^{183}$.

Por estas características normativas apontadas por Vita e Nagel, o "liberalismo igualitário" permite a construção de uma interpretação do conceito de estrutura básica adequada tanto para a formulação de princípios universais de justiça de gênero, quanto para uma representação das relações entre as esferas pública e privada atenta para suas trocas de influência mútuas e para as desigualdades e relações de dominação que se constroem e reforçam conjuntamente (afinal, a "categoria do político" é um modo de lidar com as "circunstância subjetivas de justiça"). O "liberalismo igualitário" também permite uma interpretação da estrutura básica sensível às relações entre os direitos e liberdades contidos no primeiro e no segundo princípios rawlsianos. O aspecto da separação entre as esferas pública e privada e aspecto da relação entre o primeiro e o segundo princípios andam juntos.

E isso é especialmente relevante quando nos detemos sobre o fato de que muitas mulheres permanecem em situações de violação de direitos intra-familiares - como violência doméstica e estruturas familiares restritivas de direitos de escolha - porque não possuem condições socioeconômicas e profissionais para saírem de situações

\footnotetext{
${ }^{182}$ Vita, 2008, p. 9.

183 NAGEL, Thomas. "Rawls and Liberalism". In FREEMAN, Samuel (ed.). The Cambridge Companion to Rawls. Cambridge, Cambridge University Press, 2002, pp. 62-85, trecho retirado de p. 63.
} 
opressivas. Martha Nussbaum ${ }^{184}$ e Onora O’Neill ${ }^{185}$, ao tratarem das questões de direitos humanos das mulheres, de liberdade de escolha das mulheres, proteção das mulheres contra a violência doméstica e respeito aos pertencimentos culturais, colocam como solução possível o fornecimento de alternativas de sustento econômico para mulheres que decidam romper com estruturas familiares opressivas. Esta é uma proposta que daria maior liberdade às mulheres que desejam romper com normas culturais de submissão sem intervir diretamente na vida das mulheres que preferem viver de modo tradicional e respeitando o pluralismo moral razoável. Ao pensar nesta solução, Nussbaum está informada pelas experiências de cooperativas de mulheres na Índia. É importante pensar em alternativas como esta porque, como argumenta a autora

\begin{abstract}
Even when women appear to be satisfied with such customs, we should probe more deeply. If someone who has no property rights under the law, who has had no formal education, who has no legal right to divorce, who will very likely be beaten if she seeks employment outside the home, says that she endorses traditions of modesty, purity, and self-abnegation, it is not clear that we should consider this the last word on the matter ${ }^{186}$.
\end{abstract}

Esta questão toca diretamente no problema da relação entre os direitos e liberdades civis e políticos e direitos socioeconômicos, que é um problema clássico de teoria política normativa. Muitas vezes, as mulheres não conseguem exercer direitos básicos como integridade física e direito de ir e vir porque não possuem alternativas econômicas ao sustento do pai, irmão ou marido. O direito de divórcio, quando existe juridicamente, é fortemente restringido pelo ônus econômico que pode representar para a mulher e seus filhos. Tanto Okin quanto Nussbaum escrevem longamente sobre esta questão.

Ligando todos estes problemas - o da tensão entre os direitos coletivos e igualdade de gênero, o da incompatibilidade entre justificações via moralidades compartilhadas e a afirmação da igualdade de gênero, o da impossibilidade de se pensar a justiça entre os gêneros sem questionar a separação entre o público e o privado e o da necessidade de direitos socioeconômicos para o exercício de direitos civis e políticos está tanto a questão da definição da neutralidade liberal e quanto a da lista de direitos

\footnotetext{
${ }^{184}$ Martha Nussbaum, 2001.

${ }^{185}$ O’Neill, 2000, pp. 143-167.

${ }^{186}$ Nussbaum, 2001, pp. 42-43.
} 
universais mais adequada à igualdade moral humana. Frente às questões de gênero, a neutralidade liberal não pode ser concebida como dirigida às culturas e coletividades, e sim como possibilitadora de perspectivas de vida equitativa para os indivíduos de ambos os sexos. E isso exige uma lista de direitos humanos universais ${ }^{187}$ que está longe de ser mínima, incluindo não apenas liberdades como o direito à vida, à integridade física, ao ir e vir, à liberdade de consciência e de expressão, mas também direitos socioeconômicos que permitam a saída de situações de opressão doméstica.

Reflexões que contribuam para esta justificativa são necessárias porque, dado o individualismo ético e a igualdade moral humana, isto se torna uma questão de coerência e consistência normativa internas e de adequação dos problemas normativos teóricos às relações entre coletividades e indivíduos, privado e público, direitos socioeconômicos e direitos civis e políticos. Como afirma Nussbaum,

Attending adequately the problem of gender justice has large theoretical consequences, since it involves acknowledging that the family is a political institution, not part of a 'private sphere' immune from justice. Correcting the oversight of previous theories is therefore not a matter of simply applying the same old theories to a new problem; it is a matter of getting the theoretical structure right. ${ }^{188}$

Esta justificativa também é exigida por outra necessidade de acuidade teórica, oriunda do fato de que vivemos num mundo cada vez mais global e multidimensional e é este um âmbito importante das trocas de influência recíprocas possíveis entre as diversas pessoas morais. Global porque inclui relações que se dão nas mais diversas combinações entre pessoas, empresas, organizações da sociedade civil, Estados, organismos multilaterais, blocos regionais, ONGs transnacionais, empresas transnacionais. Estas diversas combinações de relações se desenvolvem localizada e planetariamente e seus diversos atores estão envolvidos em questões em que há profunda interdependência entre as dimensões econômica, política, cultural, ambiental, de segurança etc. e nas quais cresce a importância de ameaças e riscos compartilhados transnacionalmente ${ }^{189}$. Tudo isso constrói permanentemente trocas de influência e

\footnotetext{
${ }^{187}$ Que esta pesquisa tentará pensar como uma "lista de bens primários cosmopolitas", numa crítica à "lista de capacidades funcionais humanas centrais" de Martha Nussbaum.

${ }^{188}$ Nussbaum, 2006, p. 1.

189 Este uso das palavras "global" e "multidimensional" se inspira nas definições destes termos que Rafael Villa defende em suas teses sobre a realidade dos problemas de segurança atuais. Vide VILLA, Rafael. Da Crise do Realismo à Segurança Global Multidimensional.
} 
relações de poder que afetam inescapavelmente as vidas individuais. Citando Nussbaum novamente,

Any theory of justice that aims to provide a basis for decent life chances and opportunities for all human beings must take cognizance both of inequalities internal to each nation and of inequalities between nations, and must be prepared to address the complex intersections of these inequalities in a world of increased and increasing global interconnection. ${ }^{190}$

O que fizemos até o momento foi aplicar uma leitura da concepção rawlsiana de justiça à questão da desigualdade de gênero - o que não foi feito explicitamente por Rawls, ainda que seja compatível com o espírito de sua obra - e defender que o modo de pensar a justiça e o liberalismo expostos em Uma Teoria da Justiça e O Liberalismo Político também podem ser aplicados para se pensar a justiça em países não-ocidentais, isto é, países cuja "cultura de fundo" e concepções de boa-vida predominantes não endossam o ideal de tolerância liberal, segundo o qual não devemos almejar que o Estado use seu poder coercitivo para impor nossa concepções de bem aos que discordam dela.

Isso não apenas não foi feito por Rawls, como foi criticado por ele sob a alegação de que iria contra o "espírito de tolerância liberal” obrigar povos não-liberais decentes a adotarem concepções liberais de justiça e direitos humanos, pois os indivíduos pertencentes a estas sociedades têm o direito de terem a sua filiação cultural respeitada $^{191}$. Esta argumentação baseia-se na objeção neo-hegeliana - proposta por multiculturalistas e comunitaristas - ao universalismo liberal, objeção da qual Rawls se aproxima progressivamente a partir de $O$ Liberalismo Político, ainda que nunca abandone o liberalismo. Seus últimos trabalhos enfatizam que sua concepção política da justiça requer sociedades em que há tolerância e aceitação do pluralismo moral razoável, não sendo possível expandi-la para organizações sociais em que estas estão ausentes. Isso faz com que, em Rawls, a igualdade relevante no plano internacional seja entre povos e não entre indivíduos e que, mundialmente, pessoas sejam titulares apenas

\footnotetext{
${ }^{190}$ Nussbaum, 2006, p. 225.

${ }^{191}$ RAWLS, John. O Direito dos Povos. São Paulo, Martins Fontes, 2001.
} 
de uma lista minimalista e urgente de direitos humanos ${ }^{192}$. No entanto, como fica patente ao longo de todo este paper, tendo a concordar com Amartya Sen ao intuir que

I personally would argue that Rawls over-restricts the domain of his theory, since it has usefulness beyond these limits. The theory comes into its own in the fuller context of toleration that makes Rawls's 'political conception' more extensively realizable, but the important questions of liberty, equity, and efficiency outlined by Rawls have substantial bearing even in those circumstances in which the demands of toleration are not universally accepted. ${ }^{193}$

Por fim, para finalizar esta seção, lembro que os argumentos nela expostos indicam um caminho para uma forma de cosmopolitismo moral, que é uma perspectiva normativa conforme o individualismo ético aplicada ao plano global, mas que não implica, necessariamente, a defesa de arranjos institucionais específicos entre suas demandas normativas. Ou seja, ainda há aqui uma separação entre os "cosmopolitismos políticos" ou "cosmopolitismos institucionais", que pensam uma comunidade universal em termos de instituições políticas concretas globalmente compartilhadas. O que se propôs aqui até o momento foi apenas um início de justificação para a aplicação de direitos universais que protejam os direitos de saída das mulheres em todo o mundo, independentemente dos países e comunidades em que nasceram, cujas recomendações institucionais cosmopolitas ainda precisam ser formuladas, mas que apontam para restrições a certas formas de família, de direito de família e de códigos jurídicos religiosos. Como veremos na próxima seção, Martha Nussbaum propõe um cosmopolitismo relativo às liberdades das mulheres que faz recomendações institucionais e que desenvolve um esboço de cosmopolitismo político a partir de seu cosmopolitismo moral.

A separação entre cosmopolitismo moral e cosmopolitismo político é teórica, serve para que autores do cosmopolitismo moral declarem que não são comprometidos com propostas de cosmopolitismo político específicas e que suas teorias não sejam confundidas com defesas normativas das intervenções em outros países. No entanto, se assumimos posturas de cosmopolitismo moral sobre o dever ser dos Estados e das sociedades e das relações entre pessoas morais de todo o mundo, o passo seguinte é pensar alguma forma de cosmopolitismo político que permita algum tipo de realização

\footnotetext{
192 Rawls, 2001.

${ }^{193}$ Sen, 1995b, p. 266.
} 
dos valores defendidos em nossa concepção moral cosmopolita. O cosmopolitismo moral perde todo o seu sentido enquanto empreitada teórica se dele não for possível retirar recomendações institucionais, ainda que, presentemente, os cosmopolitismos políticos tenham mostrado teoricamente incipientes e frágeis, repletos de deficiências normativas e de implausibilidade empírica. Assim, a separação entre cosmopolitismo moral e cosmopolitismo moral, de certa forma, diz mais sobre incapacidades teóriconormativas presentes de se pensar um cosmopolitismo político adequado ao cosmopolitismo moral de nossa preferência do que a uma separação entre cosmopolitismo moral e cosmopolitismo político que se sustente normativamente e teoricamente.

Passemos agora à proposta de Nussbaum daquilo que ela chama de uma "teoria parcial da justiça” que pensa as liberdades das mulheres em plano global. Trata-se, certamente, da teoria normativa mais completa e bem desenvolvida a respeito do que seria uma justiça cosmopolita que dê conta do problema global e doméstico da desigualdade de gênero e de violações às mulheres. 


\section{A proposta cosmopolita de Nussbaum para as mulheres}

No debate contemporâneo, há apenas uma construção sistemática de uma teoria e modelo normativo que lida com o problema da desigualdade de gênero internacionalmente: a de Martha Nussbaum, cujo ápice é Women and Human Development. A capapbilities approach ${ }^{194}$, publicado pela primeira vez em 2000 . O sistema normativo desenvolvido neste livro já se anunciava, de modo menos articulado, em Sex and Social Justice ${ }^{195}$, de 1999, e em diversos artigos anteriores, dando prosseguimento a reflexões sobre gênero, igualdade e qualidade de vida que se iniciaram a partir de trabalhos de Amartya Sen sobre igualdade humana e qualidade de vida em geral ${ }^{196}$ e que ficam particularmente evidentes em seu artigo "Gender Inequality and Theories of Justice" ${ }^{\prime 197}$, de 1995, publicado em coletânea organizada por Nussbaum e Glover, intitulada Women, Culture and Development. A study of human capabilities $^{198}$.

Women and Human Development defende o enfoque das capacidades proposto por Amartya Sen como a melhor abordagem para acessar a qualidade de vida das mulheres em todo o mundo e desenvolve este enfoque de forma que ele seja não apenas um modo de pensar o bem-estar, mas também uma proposição cosmopolita de "patamar mínimo" de liberdades para as mulheres.

Esta é uma proposição cosmopolita porque, além de tomar como inequívoco e evidente que devemos pensar normativamente o "dever ser" da realidade mundial, é uma reflexão de moralidade política internacional que coloca os indivíduos como

\footnotetext{
${ }^{194}$ NUSSBAUM, Martha. Women and Human Development. The capabilities approach. Cambridge, Cambridge University Press, 2001.

${ }^{195}$ NUSSBAUM, Martha. Sex and Social Justice. Oxford, Oxford University Press, 2000.

${ }^{196}$ A questão de gênero aparece na obra de Sen de um modo geral e sempre presente devido a sua preocupação com o fato de que recursos iguais são convertidos em tipos e graus diferentes de qualidade de vida e de liberdade dadas as "heterogeneidades pessoais" ou diferenças interpessoais. Por exemplo, em Sen, ser "bem nutrido" é uma liberdade que exige quantidades de recursos diferentes para crianças e adultos, para homens e mulheres, para mulheres em geral e mulheres grávidas em particular, para pessoas saudáveis e pessoas doentes, pois as necessidades nutricionais destas classes de pessoas são distintas (este exemplo aparece em diversos textos, pode ser verificado Sen, 1995, p. 264).

197 SEN, Amartya. "Gender Inequality and Theories of Justice". In NUSSBAUM, Martha \& Jonathan Glover (eds.). Women, Culture and Development. A study of human capabilities. Oxford, Clarendon Press, 1995, pp. 259-273.

${ }^{198}$ NUSSBAUM, Martha \& Jonathan Glover (eds.). Women, Culture and Development. A study of human capabilities. Oxford, Clarendon Press, 1995.
} 
unidade última de preocupação moral, acima de quaisquer coletividades, inclusive a estatal, como se percebe pela sua auto-identificação como kantiana ${ }^{199}$ e por sua afirmação de que toda a sua teoria se baseia em um princípio individualista de toda e cada pessoa como um fim em si.

E é uma proposta feminista universalista, porque toma como inequívoco e evidente que as mulheres de todo o mundo, independentemente de seus países e comunidades de pertencimento - família, religião, grupo cultural -, devem possuir acesso a um amplo número de liberdades especificados em uma lista de capacidades mundialmente defensáveis. Nisso, Martha Nussbaum coloca-se claramente contra feministas multiculturais, pós-coloniais, tradicionalistas e defensoras do paradigma do cuidado, afirmando-se como feminista liberal e internacionalista contra feminismos que pretendam que as mulheres são diferentes dos homens e diversas entre si em qualquer modo que seja relevante do ponto de vista da ética política e do que pode ser moralmente exigido dos Estados. Ainda que as mulheres possam almejar vidas diferentes, possam ter visões de mundo diversas e nascerem nas mais diversas situações políticas, econômicas, sociais e culturais, todas são portadoras de uma dignidade humana que lhes confere o direito ${ }^{200}$ moral a uma vida cujas escolhas não sejam constrangidas por situações políticas, econômicas, sociais, culturais e religiosas que lhes sejam hostis e que firam sua possibilidade de autonomia, entendida como sua possibilidade de realizar "escolhas não constrangidas", seja por uma vida de igualdade em relação aos homens ou de modéstia feminina. É esta igual liberdade, que permite tanto uma vida de igual liberdade quanto uma vida tradicional contrária à igualdade de gênero e à liberdade para as mulheres, o que faz com que Nussbaum defina sua posição como a de um "liberalismo político rawlsiano" em oposição a um "liberalismo

\footnotetext{
${ }^{199}$ Ainda que esta auto-identificação possa ser questionada por sua compreensão de diversos conceitos, como o de "toda e cada pessoa como fim em si", de escolha, de autonomia, de igualdade, de liberdade, de dignidade humana, de universalismo, de individualismo e de liberalismo. Nenhum destes conceitos é discutido com profundidade por Nussbaum em Women and Human Development, todos eles são construídos ou são implícitos sem uma discussão de como seriam pensados de uma perspectiva kantiana. Podemos considerar que não há sequer uma consideração do que é ser normativamente "kantiano" para além da afirmação de um "princípios de toda e cada pessoa como fim em si" e das pessoas como unidade última de preocupação moral. Isso é combinado com uma concepção aristotélica do dever ser da vida humana e do que é a natureza humana que talvez não seja inequivocamente compatível com ser normativamente "kantiano", se considerarmos, seguindo Onora O'Neill (1988) e Chris Brown (1997), que ser "neo-kantiano" envolve um individualismo ético que inclui alguma concepção de prioridade do justo ou prioridade da liberdade como limitação recíproca sobre o bem. ${ }^{200}$ Nussbaum afirma que, diferentemente de Sen, considera a linguagem dos direitos adequada para lidar com sua lista de capacidades humanas que devem ser respeitadas e implementadas pelos Estados de todos os países (Nussbaum, 2001, pp. 14-15).
} 
abrangente", no qual a emancipação feminina seja um dever moral para as mulheres, independentemente de suas vontades. Ao mesmo tempo, a dignidade humana igual confere às mulheres a liberdade de acesso a formas de vida não tradicionais e à "escolha genuína" (não constrangida ou autônoma), mesmo que seus discursos afirmem que o que elas acham moralmente correto é seguir uma vida de obediência e modéstia feminina frente aos homens e às comunidades, numa demonstração clara de preocupação normativa com as "preferências adaptativas" que as mulheres desenvolvem ao se construírem como pessoas "generificadas" em ambientes anti-igualitários do ponto de vista do gênero.

Como pretende respeitar normativamente tanto a dignidade humana quanto as formulações que as mulheres fazem a respeito de suas vidas e suas relações com suas comunidades e culturas, Nussbaum formula como objetivo e percurso de sua teoria que

The aim of this project as a whole is to provide the philosophical underpinning for an account of basic constitutional principles that should be respected and implemented by the governments of all nations, as a bare minimum of what respect for human dignity requires. (...) I shall argue that the best approach to this idea of basic social minimum is provided by an approach that focuses on human capabilities, that is, what people are actually able to do and to be - in a way informed by intuitive idea of a life that is worthy of the dignity of the human being. I shall identify a list of central human capabilities $^{201}$, setting them in the context of a type of political liberalism that makes them specifically political goals and presents them in a manner free of any specific metaphysical grounding. In this way, I argue, the capability can be the object of an overlapping consensus $^{202}$ among people who otherwise have very different comprehensive conceptions of the good. And I shall argue that the capabilities in question should be pursued for each and every person, treating each as an end and none as a mere tool of the ends of others: thus I adopt a principle of each person's capability, based on a principle of each person as an end. Women have to often been treated as the supporters of the ends of others, rather than as ends in their own right; thus this principle has particular critical force with regard to women's lives. Finally, my approach uses the idea of a threshold level of each capability, beneath which it is held that truly

\footnotetext{
${ }^{201}$ Adianto que argumentarei por uma lista de bens primários cosmopolita em substituição a esta lista de capacidades humanas centrais.

${ }^{202}$ Argumentarei que bens primários são um objeto mais adequado para um "consenso sobreposto" e que princípios cosmopolitas e kantianos de igualdade e liberdade de gênero e uma lista de bens primários cosmopolitas deve ser pensada não a partir de um "consenso sobreposto" como modo de justificação, mas do "princípio liberal de legitimidade" formulado por Rawls e do "axioma de igualdade moral humana".
} 
human functioning is not available to citizens; the social goal should be understood in terms of getting citizens above this capability threshold ${ }^{203}$.

Vejamos melhor o que está implicado neste projeto.

Um primeiro ponto a ser esclarecido é que, ao adotar o enfoque das capacidades de Sen, Martha Nussbaum incorpora textualmente quase ${ }^{204}$ toda a crítica deste autor a concepções de justiça que defendam igualdade de recursos para o exercício da liberdade e das diversas concepções de bem, inclusive a crítica de Sen à métrica dos "bens primários ${ }^{205}$, por estes serem meios para se alcançar liberdade e bem-estar.

Segundo Sen, o que importa para a qualidade de vida e bem-estar não são as titularidades de bens e recursos em si, mas os estados e atividades valiosos que estes permitem, chamado "funcionamentos" [functionings]. Em suas palavras,

O conceito de "funcionamentos" (...) reflete as várias coisas que uma pessoa pode considerar valioso fazer ou ter. Os funcionamentos valorizados podem variar dos elementares, como ser adequadamente nutrido e livre de doenças evitáveis, a atividades ou estados pessoais muito complexos, como poder participar da vida da comunidade e ter respeito próprio ${ }^{206}$.

O problema das concepções de bem-estar e justiça focadas na igualdade de renda e recursos é que os mesmos bens e recursos permitem, a pessoas distintas, diferentes estados e atividades. O que causa conversões diferentes de recursos e bens em "funcionamentos" são: as próprias "heterogeneidades pessoais", que causam necessidades físicas e psicológicas distintas; "diversidades ambientais", como circunstâncias climáticas, presença de doenças infecciosas, poluição e diversas vantagens e desvantagens ambientais; "variações no clima social", que inclui condições sociais, econômicas e políticas em geral, como a presença de políticas sociais e de segurança; "diferenças de perspectivas relativas", dependentes de padrões de comportamento socialmente estabelecidos, convenções e costumes; e "distribuição intrafamiliar" das rendas e bens auferidos por seus membros. Estes diferentes fatores que atuam sobre a conversão de bens e recursos em bem-estar são inter-relacionados e,

\footnotetext{
${ }^{203}$ Nussbaum, 2001, pp. 5-6.

${ }^{204}$ Um ponto importante em que Nussbaum não incorpora à crítica de Sen a Rawls é a sua afirmação de que sua lista de capacidades não é incompatível com a linguagem dos direitos.

${ }^{205}$ Esta métrica será exposta a partir da p. 111.

${ }^{206}$ Sen, 2001, p. 95.
} 
como aponta o próprio Sen, incidem diretamente sobre as desigualdades de bem-estar e exercício de liberdades entre homens e mulheres ${ }^{207}$. Segundo Sen, o problema do enfoque rawlsiano dos "bens primários" é justamente que estes são recursos para o bemestar e a liberdade e representam diferentes tipos e graus de bem-estar e liberdade de acordo com estas variações ${ }^{208}$, assim,

Se o objetivo é concentrar-se na oportunidade real de o indivíduo promover seus objetivos (como Rawls recomenda explicitamente), então será preciso levar em conta não apenas os bens primários que as pessoas possuem, mas também as características pessoais [e sociais, se levarmos todas as variações mencionadas acima a sério] relevantes que governam a conversão de bem primários na capacidade de a pessoa promover seus objetivos ${ }^{209}$.

De toda forma, o que importa para pensarmos o bem-estar efetivo não são apenas os "funcionamentos" realizados, mas as possibilidades de "funcionamentos" cujo exercício é possível para cada um e que as pessoas podem combinar de diferentes maneiras. Pois bem, capacidade é a liberdade efetiva de alcançar ou realizar bem-estar e de escolher entre diferentes tipos de vida expressos em diferentes combinações de “funcionamentos". Nas palavras do próprio Sen:
A "capacidade" (...) de uma pessoa consiste nas combinações alternativas de funcionamentos cuja realização é factível com ela. Portanto, a capacidade é um tipo de liberdade: a liberdade substantiva de realizar combinações alternativas de funcionamentos (ou, menos formalmente expresso, a liberdade para ter estilos de vida diversos) $)^{210}$.

Por isso Martha Nussbaum opta por defender uma "lista de capacidades funcionais humanas centrais" [central human functional capabilities] a serem respeitadas e implementadas em todos os países e não uma lista de "funcionamentos": porque, como vimos anteriormente, esta autora traz no cerne de suas propostas normativas o valor da "escolha não constrangida" ou da "escolha genuína" como indispensável à vida verdadeiramente humana.

Assim, capacidades são o "espaço avaliatório" do bem-estar e da qualidade de vida e o equalisadum próprio ao âmbito do cosmopolitismo moral e político porque constituem uma métrica que permite acessar o que é possível às mulheres ser e fazer e

\footnotetext{
${ }^{207}$ Sen, 2001, pp. 90-91.

${ }^{208}$ Sen, 2001, pp. 92-93 e Sen, 1995, p. 264.

${ }^{209}$ Sen, 2001, p. 95.

${ }^{210}$ Sen, 2001, p. 95.
} 
não apenas o que elas fazem e são em suas vidas cotidianas. As capacidades são um critério de entendimento do mundo e das relações humanas e também algo necessário à diminuição das desigualdades e violações da dignidade humana. Por isso

We ask not only about the person's satisfaction with what she does, but about what she does, and what she is in a position to do (what her opportunities and liberties are). And we ask not just about the resources that are sitting around, but about how those do or do not go to work, enabling Vasanti [ou qualquer outra mulher] to function in a fully human way ${ }^{211}$.

Para a autora, isso justifica, simultaneamente, que o utilitarismo, a "justiça como equidade" e também todas as defesas de igualdade de recursos e concepções de bemestar centradas na renda sejam rejeitadas.

E por este entendimento da qualidade de vida e bem-estar, as capacidades são também, segundo Nussbaum, o espaço adequado para se fazer reivindicações e prescrições normativas frente aos Estados de todos os países do mundo. Daí o estabelecimento de uma lista de capacidades que constitui um patamar mínimo de liberdade que deve ser acessível a todos para que seja possível a realização de "escolhas genuínas" que tornem a vida digna e valiosa de ser vivida para as mulheres. Repetindo, para esta autora, a dignidade humana é indissociável da possibilidade de fazer "escolhas não constrangidas", é isto que permite "to live in a truly human way". Respeitar o valor desta "vida verdadeiramente humana" é estar de acordo com um "principle of each person as an end" que conduz a um "principle of each person's capability" que se expressa na lista de "capacidades funcionais humanas centrais", que reproduzo na íntegra.

\section{CENTRAL HUMAN FUNCTIONAL CAPABILITIES ${ }^{212}$}

1. Life. Being able to live to the end of a human life of normal length; not dying prematurely, or before one's life is so reduced as to be not worth living.

\footnotetext{
${ }^{211}$ Nussbaum, 2001, p. 71.

${ }^{212}$ Nussbaum, 2001, pp. 78-80.
} 
2. Bodily Health. Being able to have good health, including reproductive health; to be adequately nourished; to have adequate shelter.

3. Bodily Integrity. Being able to move freely from place to place; having one's bodily boundaries treated as sovereign, i.e. being able to be secure against assault, including sexual assault, child abuse, and domestic violence; having opportunities for sexual satisfaction and for choice in matters of reproduction.

4. Senses, Imagination, and Thought. Being able to use the senses, to imagine, think, and reason - and to do these things in a 'truly human' way, a way informed and cultivated by an adequate education, including, but by no means limited to, literacy and basic mathematical and scientific training. Being able to use imagination and thought in connection with experiencing and producing self-expressive works and events of one's own choice, religious, literacy, musical, and so forth. Being able to use one's mind in ways protected by guarantees of freedom of expression with respect to both political and artistic speech, and freedom of religious exercise. Being able to search for the ultimate meaning of life in one's way. Being able to have pleasure experiences, and to avoid non-necessary pain.

5. Emotions. Being able to have attachments to things and people outside ourselves; to love those who love and care for us, to grieve at their absence; in general, to love, to grieve, to experience longing, gratitude, and justified anger. Not having one's emotional development blighted by overwhelming fear and anxiety, or by traumatic events of abuse or neglect. (Supporting this capability means supporting forms of human association that can be shown to be crucial in their development.)

6. Practical Reason. Being able to form a conception of the good and to engage in critical reflection about the planning of one's life. (This entails protection for liberty of conscience.)

7. Affiliation. A. Being able to live with and toward others, to recognize and show concern for other human beings, to engage in various forms of social interaction; to be able to imagine the situation of another and to have compassion for that situation; to have the capability for both justice and friendship (Protecting this capability means protecting institutions that constitute and nourish such forms of affiliation, and also protecting the freedom of assembly and political speech.) 
B. Having the social bases of self-respect and non-humiliation; being able to be treated as a dignified being whose worth is equal to that of others. This entails, at minimum, protections against discrimination on the basis of race, sex, sexual orientation, religion, caste, ethnicity, or national origin. In work, being able to work as a human being, exercising practical reason and entering into meaningful relationships of mutual recognition with other workers.

8. Other Species. Being able to live with concern for and in relation to animals, plants, and the world of nature.

9. Play. Being able to laugh, to play, to enjoy recreational activities.

10. Control over One's Environment. A. Political. Being able to participate effectively in political choices that govern one's life; having the right of political participation, protections of free speech and association.

B. Material. Being able to hold property (both land and movable goods), not just formally but in terms of real opportunity; and having property rights on an equal basis with others; having the right to seek employment on an equal basis with others; having the freedom from unwarranted search and seizure.

Estas capacidades são vistas por Nussbaum como separadas entre si, cada uma possui uma qualidade própria e distinta das demais ${ }^{213}$ e não há nenhuma prioridade lexical entre elas ${ }^{214}$.

Esta é uma lista bastante ampla de capacidades humanas centrais que, segundo Nussbaum, devem ser base de princípios constitucionais e que constituem um "mínimo social básico" e um "threshold level of each capability", próprio de uma "teoria parcial da justiça" e não uma concepção completa de justiça social similar a "justiça como equidade" rawlsiana, por exemplo ${ }^{215}$. Este caráter "mínimo" faz parte do que justifica que esta lista seja moralmente exigível de qualquer Estado do mundo e que torna a lista, "intuitivamente" elaborada, passível de ser objeto de um "consenso sobreposto" e

\footnotetext{
${ }^{213}$ Nussbaum, 2001, p. 81.

${ }^{214}$ Nussbaum, 2001, p. 12.

${ }^{215}$ Nussbaum, 2001, pp. 5-6.
} 
apropriada a um "liberalismo político" que prescinde de bases metafísicas e que difere de um "liberalismo abrangente" 216.

Tudo pode ser questionado no parágrafo anterior. A começar pelo fato de que esta lista provê apenas um mínimo social básico ${ }^{217}$ e constitui apenas uma "teoria parcial da justiça". Basta atentarmos que as noções de "vida verdadeiramente humana", de dignidade humana e de sociedade e toda a lista de capacidades trazem implícitas uma ideia de natureza humana que bebe em Aristóteles e $\operatorname{Marx}^{218}$ para vermos que esta lista está além de um "mínimo social básico" e de a teoria da justiça kantiana, sendo mais próxima a uma concepção de bem que esta autora crê ser interculturalmente encontrável e defensável:

The core idea is that of the human being as a dignified free being who shapes his or her own life in cooperation and reciprocity with others, rather than being passively shaped or pushed around by the world in the manner of a "flock" or "herd" animal. A life that is really human is one that is shaped throughout by these human powers of practical reason and sociability.

This idea of human dignity has broad cross-cultural resonance and intuitive power. We can think of it as the idea that lies at the heart of tragic artworks, in whatever culture ${ }^{219}$.

Uma teoria normativa que parte desta concepção de dignidade e vida verdadeiramente humanas, em uma acepção rawlsiana, é mais do que uma teoria da justiça, é um "ideal social” ou parte de um. E, definitivamente, estaria mais próxima de um "liberalismo abrangente" do que de um "liberalismo político" independentemente de bases metafísicas, de modo que não poderia ser objeto de um "consenso sobreposto" de

\footnotetext{
${ }^{216}$ Vide afirmações feitas por Nussbaum nas pp. 5-6, logo que a autora anuncia seu projeto normativo de "teoria parcial da justiça".

${ }^{217}$ Acredito que um mínimo social seria algo semelhante às concepções minimalistas de direitos humanos, como a defendida por Rawls em $O$ Direito dos Povos e que remete a de Henry Shue: "Among the human rights are the right to life (to the means of subsistence and security); to liberty (to freedom from slavery, serfdom, and forced occupation, and to a sufficient measure of liberty of conscience to ensure freedom of religion and thought); to property (personal property); and to formal equality as expressed by the rules of natural justice (that is, that similar cases be treated similarly). Human rights, as thus understood, cannot be rejected as peculiarly liberal or special do the Western tradition" (Rawls, John. The Law of Peoples. Cambridge-Mass., Harvard University Press, 2002, p. 65.)

${ }^{218}$ Autores aos quais Nussbaum remete explicitamente para defender sua concepção de vida verdadeiramente humana e de escolha não constrangida, por exemplo em: "The intuitive idea behind the approach is twofold: first, that certain functions are particularly central in human life, in the sense that their presence or absence in typically understood to be a mark of the presence or absence of human life; and second - this is what Marx found in Aristotle - that there is something that it is to do these functions in a truly human way, not a merely animal way" (Nussbaum, 2001, pp. 71-72).

${ }^{219}$ Nussbaum, 2001, p. 72.
} 
uma sociedade liberal e, menos ainda, de um "consenso sobreposto" intercultural mundial, isto é, no plano de maior pluralismo moral existente e possível.

Um "liberalismo político" é capaz de formular uma "categoria do político" independentemente de doutrinas abrangentes de bem e que, em um "consenso sobreposto", é free standing em relação a elas. "Doutrinas abrangentes de bem" são aquelas que ditam os valores das várias dimensões da vida (política, religiosa, familiar etc.), ligando-as entre si $^{220}$. Uma “doutrina abrangente" é "razoável" quando não requer que o poder coercitivo estatal seja utilizado para impor-se sobre as demais, aceitando uma certa margem de tolerância e de pluralismo moral.

A "razoabilidade" é aquilo que caracteriza a motivação moral de uma perspectiva contratualista de modo independente das circunstâncias culturais. Enquanto qualidade das doutrinas abrangentes, a razoabilidade é uma característica cultural das sociedades democráticas liberais, em que os cidadãos são vistos como livres e iguais, a sociedade é entendida como um "sistema imparcial [quanto aos indivíduos e às concepções de bem] de cooperação ao longo do tempo", as doutrinas são apenas "parcialmente abrangentes" e a "categoria do político" pode ser pensada separadamente das doutrinas abrangentes particulares e é free standing em relação a elas. Isso significa que há valores morais exclusivamente políticos, independentes das doutrinas parcialmente abrangentes em que se inserem ${ }^{221}$. Uma doutrina abrangente é razoável quando não requer que o poder coercitivo estatal seja exercido a seu favor e conforme seus valores não-políticos (isto é, pertencentes a outras esferas da vida, como a religiosa, por exemplo). E os valores "políticos" são compartilhados por todas as doutrinas abrangentes razoáveis. Assim, a razoabilidade implica tolerância o suficiente para que seja possível o convívio respeitoso com diferenças com as quais não se concorda; tolerância esta que é comum às várias doutrinas abrangentes que convivem numa sociedade democrática liberal e que constitui uma cultura política de fundo cujo teor é em si liberal ${ }^{222}$.

A concepção de natureza e vida verdadeiramente humanas presente naquilo que Nussbaum considera ser sua "teoria parcial da justiça" e a lista de capacidades que

\footnotetext{
${ }^{220}$ Rawls, 2000, pp. 82-101.

${ }^{221}$ Rawls, 2000, p. 20 e Rawls, 1997, pp. 143-147.

${ }^{222}$ Rawls, 2000, pp. 82-101.
} 
decorre "intuitivamente" desta concepção de humanidade, apesar de serem vistas pela autora como traços de forte ressonância intercultural, são parte de doutrinas abrangentes do bem bastante específicas e que constituem o que Michael Walzer chama de "moralidade espessas"223, não podendo ser objeto de um "consenso sobreposto" mundial. Em particular, a igualdade de gênero e o "threshold level of each capability" que a possibilitaria jamais passariam pelo critério do "consenso sobreposto" mundial, pois as doutrinas abrangentes no âmbito internacional, muito frequentemente, não passariam pelo teste da razoabilidade, vide a enorme quantidade de leis e políticas de forte viés religioso que existem em tantos países e que são especialmente fortes no que diz respeito à desigualdade de gênero. A incompatibilidade da igualdade de gênero com um "consenso sobreposto" mundial fica especialmente evidente pelo fato de que os documentos de direitos humanos das mulheres - como a Convenção sobre a Eliminação de Todas as Formas de Discriminação contra as Mulheres - são os que menos países signatários possuem.

Martha Nussbaum pensa um "consenso sobreposto" mundial pró-igualdade de gênero justamente por pensá-lo de modo bastante distinto do rawlsiano. A começar pelo fato de que a sua ideia de "consenso sobreposto" não exige uma cultura comum liberal de fundo em que é possível construir uma "categoria do político" a partir de elementos já existentes nas diversas “doutrinas abrangentes de bem”, que são razoáveis. O plano internacional para o qual olha Nussbaum não possui uma cultura política comum e é repleto de doutrinas abrangentes que não são razoáveis. De modo que a autora elabora um consenso sobreposto que opera não pela ideia de "sobreposição" que constrói uma “categoria do político", mas por uma seleção intuitiva de traços e noções de diversas doutrinas abrangentes que são unidas pela reflexão da autora em uma agrupamento de valores compatíveis com a sua concepção de "vida verdadeiramente humana", o que em nada se assemelha a "categoria do político" própria de um "liberalismo político não metafísico". Assim, ao contrário do que Nussbaum pensa, ela seria porta-voz de um "liberalismo abrangente", isto é, uma doutrina que é liberal por comportar uma tolerância grande ao pluralismo moral (desde que este permita escolhas não constrangidas), mas que traz implícito uma concepção de bem forte.

${ }^{223}$ Vide pp. 50-51 deste working paper. 
Não ser passível de ser objeto de um "consenso sobreposto" não é o maior problema desta lista, dado que o axioma da igualdade moral humana é anterior a qualquer mecanismo através do qual pensamos a moralidade política e a "categoria do político". A fragilidade da ideia de se aplicar um "consenso sobreposto" ao plano cosmopolita se evidencia pela probabilidade de que seria mais fácil encontrar apoio internacional para a defesa da desigualdade de gênero do que para o contrário ${ }^{224}$. Mesmo assim, não poder passar por um "consenso sobreposto" mostra que se trata de uma moralidade demasiado "espessa" para ser proposta em âmbito internacional. Constituir um "liberalismo abrangente" ou uma concepção liberal de bem é bastante grave, dado que o pluralismo moral razoável deve ser respeitado em nome do próprio respeito às mulheres, já que muitas delas optam e optariam por modos de vida tradicionais e considerá-las é importante ao se propor e justificar uma justiça cosmopolita para as mulheres. Em suma, esta lista é menos capaz de lidar com o pluralismo moral - mesmo em uma perspectiva individualista de como respeitar o pluralismo - do que seria uma lista de bens primários, pois interfere mais sobre as concepções de bem. E o faz justamente porque seu equalisandum expressa estados e atividades valiosos e não meios e recursos para se realizar estes estados e atividades.

Além disso, creio que uma lista de capacidade acessa de modo menos adequado a estrutura básica e suas relações de poder e coerção, pois uma lista de bens primários cosmopolitas seria um equalisandum que afirmaria mais nitidamente as liberdades iguais que devem ser respeitadas em todos os planos de relações entre as pessoas morais e que são englobados pelos três âmbitos da justiça: local, social e cosmopolita. Uma lista de bens primários, por delimitar mais nitidamente e restritamente o que é importante para as mulheres terem seu "direito de saída pleno" institucionalmente respeitado, é menos passível de gerar "desrespeito oficial" 225 pelos direitos das mulheres.

Dado o problema de compatibilizar o respeito à igualdade humana das mulheres e o respeito ao pluralismo moral, passaremos a uma breve discussão das objeções anti-

\footnotetext{
${ }^{224}$ Por mais que Nussbaum afirme que a ideia de dignidade humana das mulheres esteja presente em todas as culturas em de grandes histórias e tragédias, a desigualdade de gênero está mais presente ainda, como fica patente pelos dados apresentados no início deste trabalho.

${ }^{225}$ Desrespeito estatal, que pode ser tanto diretamente cometido pelo Estado, quanto negligenciado sistematicamente por ele. Conceito retirado de Thomas Pogge. (POGGE, Thomas. "How Should Human Rights Be Conceived?" In Patrick Hayden (ed.). The Philosophy of Human Rights. St. Paul, Paragon House, 2001, pp. 187-211.)
} 
cosmopolitas a concepções de equalisanda globais que são dirigidas a concepções de direitos humanos e justiça global. Para em seguida elaborarmos um breve esboço de uma concepção cosmopolita que acreditamos ser capaz de resistir aos desafios impostos pela "objeção neo-hegeliana": um projeto de bens primários cosmopolitas que sejam, simultaneamente, mais respeitoso frente ao pluralismo moral e mais capaz de acessar as interseções e meandros entre as justiças local, social e cosmopolita, entre público e privado, entre tolerância como virtude institucional e enquanto virtude social. 


\section{A objeção neo-hegeliana e o problema das métricas cosmopolitas}

Dado que consideramos a "teoria parcial da justiça" construída por Martha Nussbaum para lidar com a desigualdade de gênero mundial um "liberalismo abrangente" que se relaciona de modo problemático com o pluralismo moral global, dedicaremos esta seção ao problema da relação entre cultura e cosmopolitismo.

A crítica ao universalismo moral segundo a qual devemos respeitar e tolerar culturas através de direitos coletivos a fim de respeitar verdadeiramente os direitos individuais é chamada por Onora $\mathrm{O}^{\prime} \mathrm{Neill}^{226}$ e Chris Brown ${ }^{227}$ de neo-hegeliana. E, como mostram Ann-Belinda Preis ${ }^{228}$ e Karen Engle ${ }^{229}$, é uma herança boasiana que o debate sobre a tolerância e os direitos humanos carrega e, como vemos em Lisa Weeden, re-aparece na concepção de cultura de Clifford Geertz ${ }^{230}$. Esta crítica concebe um tipo de relação entre cultura, identidade e integridade individual extremamente forte nos debates sobre justiça e direitos humanos. A semelhança entre os argumentos neohegelianos e os argumentos boasianos a favor dos direitos coletivos e dos direitos culturais permitiram que ambos se reforçassem mutuamente e dessem fôlego à produção comunitarista e relativista e também à produção pragmática contra o universalismo dos direitos humanos e contra o pensamento igualitário liberal em âmbito global.

A crítica que, como O’Neill e Brown, chamaremos de neo-hegeliana, argumenta que a neutralidade liberal é sempre uma concepção paroquial excludente e dominadora das culturas em que o político ou o justo não pode ser $^{231}$ separado das concepções morais extensas, que vinculam política e justiça a crenças culturais que, na modernidade ocidental, podem ser intelectualmente separadas da esfera política. Trata-se da negação da possibilidade da neutralidade cultural e de uma "categoria do político", categoria esta

\footnotetext{
${ }^{226}$ O’NEILL, Onora. “Ethical Reasoning and Ideological Pluralism." Ethics, Vol. 98, No. 4, 1988, pp. 705722.

227 BROWN, Chris. "Theories of International Justice." British Journal of Political Science, Vol. 27, No. 2, 1997, pp. 103-127.

${ }^{228}$ PREIS, Ann-Belinda. "Human Rights as Cultural Practice: An Anthropological Critique." Human Rights Quarterly, Vol. 18, No. 2, 1996. Acessado em: http://muse.jhu.edu/journals/human_rights_quarterly/v018/18.2preis.html.

${ }^{229}$ ENGLE, Karen. "From Skepticism to Embrace: Human Rights and the American Anthropological Association from 1947-1999." Human Rights Quarterly, Vol. 23, 2001, pp. 436-559.

${ }^{230}$ WEDEEN, Lisa. "Conceptualizing Culture: possibilities for Political Science." American Political Science Review, Vol. 96, No. 4, dezembro de 2002, pp. 713-728.

${ }^{231}$ Ao menos segundo esses críticos.
} 
que, como aponta O'Neill ${ }^{232}$, pode ser uma "abstração" para os "insiders" de determinadas tradições liberais, mas que é uma "idealização"233 para seus "outsiders", pois é informada por um ideal de cidadania em que os cidadãos possuem um tipo de independência mútua que lhes tira o desejo e a necessidade de utilizar o poder coercitivo estatal $^{234}$ para obrigar os demais a professarem sua concepção de bem e que, possivelmente, faz da moralidade política contida nos princípios de justiça a única cultura compartilhada ${ }^{235}$.

Esta neutralidade frente às culturas - construída pela "categoria do político" e por seu ideal de "independência mútua dos cidadãos" - sendo uma ilusão dentro das fronteiras nacionais, o seria ainda mais no plano mundial. A crítica comunitarista defende que a cidadania mutuamente independente como base da teoria da justiça internacional expulsaria muitos Sittlichkeiten do âmbito da justiça e, pior ainda, do âmbito da vida humana, já que minaria as bases da identidade. Conforme argumenta Taylor a respeito do plano doméstico, a cultura não é instrumental ou externa aos bens sociais e culturais e às identidades social e culturalmente situadas, ao contrário, é essencial à sua constituição e, se a liberdade de constituição da identidade deve ser protegida, a cultura também deve ser, o que justifica direitos coletivos acima das liberdades individuais ${ }^{236}$. Assim, para Taylor, a única maneira de pensarmos direitos humanos é procurar valores existentes em todas as culturas e que possam construir um consenso global que remete à ideia rawlsiana de "consenso de sobreposição" ${ }^{237}$, como veremos adiante.

Um primeiro problema da objeção neo-hegeliana às concepções de justiça global e de direitos humanos é que ela utiliza uma concepção de comunidade, de cultura, de identidade cultural e da relação destas com as pessoas que ao invés de ser sensível aos contextos e significados locais como pensam seus defensores, é uma "idealização", do

\footnotetext{
${ }^{232}$ O’ Neill, 1988, p. 713.

233 De acordo com definição de O’Neill, uma abstração é um mecanismo de raciocínio que opera omissões seletivas e indispensável à filosofia moral tanto quanto à ciência. Segundo ela, "anybody who wants to appeal beyond past institutions and categories of discourse now established and to reach a wide or universal audience is bound to use and advocate reasoning that abstracts from features of the current scene". As idealizações, por seu lado, seriam acréscimos à abstração que tornam o sistema inadequado onde esses acréscimos não existem. O’Neill, 1988, pp. 711-712.

${ }^{234}$ Tanto em políticas estatais de reconhecimento quanto no uso do poder coercitivo estatal a favor da predominância de um doutrina abrangente de bem.

${ }^{235}$ O'Neill, 1988, p. 713.

${ }^{236}$ Taylor, 2000, p. 153.

${ }^{237}$ Taylor, 2001, pp. 409-410.
} 
mesmo modo que a suposição de independência mútua entre os cidadãos e os "eus desencarnados" criticados por Michael Sandel ${ }^{238}$.

Conforme Ann-Belinda Preis ${ }^{239}$, Amelie Rorty ${ }^{240}$ e Katherine Fierlbeck ${ }^{241}$ mostram, os defensores da objeção neo-hegeliana, ao defenderem legislações cujos sujeitos de direito são coletivos, tratam a cultura como se esta fosse estática, homogênea e perfeitamente coerente e coesa ${ }^{242}$, sem valores internos contraditórios entre si e em disputa. E consideram que os indivíduos dependem de um contexto cultural seguro, que não sofre questionamentos e críticas para que consigam fazer escolhas morais que sintam como significativas e valiosas e para que consigam sobreviver. No entanto, a cultura não é e nunca foi estática, homogênea e portadora de valores completamente coerentes entre $\mathrm{si}^{243}$. E as pessoas de todas as épocas e lugares tiveram que conviver com fato de que não há valores culturais inquestionáveis dentro de nenhuma coletividade. "Idealizações" neo-hegelianas que não dão conta disso são tão insensíveis à diversidade e aos contextos culturais quanto as "idealizações" do universalismo abstrato. Isso torna plausível pensarmos sujeitos de direito individuais e direitos individuais tanto quando pensamos direitos humanos e justiça global, quanto ao refletirmos sobre justiça de gênero nos contextos doméstico e mundial.

Uma outra crítica importante à objeção neo-hegeliana é que direitos individuais não podem ser subordinados a direitos culturais e nem ao direito a um contexto cultural seguro, pois, levando a objeção neo-hegeliana a suas últimas consequências temos aberrações como a impossibilidade normativa de se criticar práticas culturais como a

\footnotetext{
${ }^{238}$ SANDEL, Michael. Liberalism and the Limits of Justice. Cambridge: Cambridge University Press, 2008, 11a. ed. (equivalente à 2a. ed.). Estes "eus desencarnados" são as partes contratantes da posição original rawlsiana, com todas as suas qualificações, desde o véu de ignorância, à sua racionalidade, aos limites formais do conceito do justo etc.

239 Preis, 1996.

${ }^{240}$ RORTY, Amelie. "The Hidden Politics of Cultural Identification." Political Theory, Vol. 22, No. 1, 1994, pp. 152-166.

${ }^{241}$ FIERLBECK, Katherine. "The Ambivalent Potential of Cultural Identity." Canadian Journal of Political Science, Vol. 29, No. 1, 1996, pp. 3-22.

${ }^{242}$ Segundo boa parte da teoria antropológica a partir do século XX, as "comunidades primitivas" descritas desta forma nunca existiram. As próprias etnografias realizadas pelos antropólogos culturalistas e as "descrições densas" de Geertz mostram disputas de significado.

${ }^{243}$ Mesmo o culturalismo norte-americano do início do século XX e Geertz não pensavam assim ao defender que as idéias e valores só podem ser compreendidos dentro de seus contextos culturais. A confusão acima pertence mais aos ativistas e teóricos dos direitos humanos e aos textos da American Anthropological Association sobre direitos humanos do que as antropólogos. E o próprio Walzer dedica muitas de suas reflexões ao modo como a cultura contém valores diversos e contraditórios entre si, o que permite a prática do que ele denomina "criticismo social".
} 
criminalização da homossexualidade no Irã e a legalidade do assassinato de mulheres por questões de honra de seus pais, irmãos e maridos em países do Oriente Médio e da Antiga Iugoslávia. Se os direitos culturais são os moralmente mais relevantes para os indivíduos, qual o lugar dos direitos individuais das mulheres e homossexuais destes países? Qual o lugar dos direitos de saída dos grupos que são minorias e das pessoas que são minorias internas a grupos? A defesa normativa dos direitos culturais torna o espaço para a justiça global e para a justiça de gênero excessivamente limitados, ao ponto da insignificância, pois, como lembra Susan Okin, direitos coletivos são potencialmente anti-igualdade de gênero $^{244}$. Como mostra Joan Scott, gênero é a organização social da relação entre os $\operatorname{sexos}^{245}$. Sendo assim, não podemos defender, ao mesmo tempo, que gênero é uma arbitrariedade moral que não deve influenciar o exercício de liberdades individuais e que a justiça internacional exige direitos coletivos a fim de possibilitar o respeito à diversidade cultural e ao pertencimento comunitário.

Como vimos, segundo Okin, a maior parte da teoria comunitarista não percebeu esta tensão por dois motivos principais: (1) porque negligencia o fato de que as comunidades não são monolíticas e coesas, possuindo muitas diferenças internas; e (2) porque não presta a devida atenção às implicações da vida privada. Ao se restringirem ao fato de que os indivíduos precisam de sua cultura e que apenas dentro de culturas os indivíduos conseguem desenvolver autoestima, autorrespeito e capacidade de escolha, os multiculturalistas se esquecem de que os grupos culturais reservam papéis diferentes para seus membros e que o senso de si e a capacidade de decisão possibilitada pela cultura são formados e transmitidos, primeiramente, na vida doméstica e familiar. A esfera pessoal, sexual e reprodutiva é um tema central das práticas e regras culturais e, dentro disso ${ }^{246}$ :

The defense of 'cultural practices' is likely to have much greater impact on the lives of women and girls than on those of men and boys, since far more of women's time and energy goes into preserving and maintaining the personal, familial, and reproductive side of life. Obviously, culture is not only about domestic arrangements, but they do provide a major focus of most contemporary cultures. Home is, after all, where much of culture is practiced, preserved, and transmitted to the young. On the other hand, the distribution of responsibilities and power at

\footnotetext{
244 Okin, 1999.

${ }^{245}$ Scott, 1986.

${ }^{246}$ Okin, 1999, pp. 12-13.
} 
home has a major impact on who can participate in and influence the more public parts of the cultural life, where rules and regulations about both public and private life are made. The more a culture requires or expect of women in the domestic sphere, the less opportunity they have of achieving equality with men in either sphere. ${ }^{247}$

Por tudo isso, acredito que a forma como Rawls interpretou o princípio de tolerância liberal atrelando-o à ideia neo-hegeliana de que devemos respeitar a filiação cultural das pessoas leva o pluralismo entre culturas a sério, mas não o pluralismo entre indivíduos. Além disso, negligencia as relações de coerção culturalmente construídas das quais família e gênero são um exemplo - e que preenchem os requisitos de seu conceito de estrutura básica e atendem aos motivos porque estas deve ser o objeto da justiça.

No entanto, não basta descartar a objeção neo-hegeliana através da argumentação de que os indivíduos sobrevivem ao questionamento de algumas de suas práticas culturais e de que a cultura constrói desigualdades e hierarquias. Pois ela questiona a própria possibilidade intelectual de se pensar princípios de justiça e direitos humanos de alcance cosmopolita, de se pensar uma "justice without borders. „248 Vejamos este problema através da discussão do ceticismo interno e do método que Walzer propõe para se pensar a moralidade internacional, com seus reflexos sobre a justiça de gênero.

“Ceticismo interno" é um termo cunhado por Ronaldo Dworkin para se referir à postura cética que questiona a validade das convicções e julgamentos morais substantivos de alcance universal. Para seus adeptos, juízos morais só são verdadeiros em relação às formas de vida e comunidades dos quais fazem parte ${ }^{249}$, o que faz com que esta tese costume andar junto com a "objeção neo-hegeliana". Se o "ceticismo interno" estiver correto do ponto de vista normativo, a defesa de concepções de justiça global e de justiça de gênero além fronteiras não é possível, pois dependem de um universalismo e de um individualismo que não é encontrado na maior parte das culturas

\footnotetext{
${ }^{247}$ Okin, 1999, p. 13.

${ }^{248}$ Termo de Kok-Chor Tan.

249 DWORKIN, Ronald. "Objectivity and Truth: You'd Better believe It." Philosophy and Public Affairs, Vol. 24, No. 2. 1996, pp. 87-139.
} 
e modos de vida. O trabalho de Michael Walzer a respeito dos modos de argumentação moral e da moralidade internacional possível são um exemplo de sistematização deste tipo de ceticismo moral.

Para este autor, como a moralidade é indissociável da construção social de significados e esta é sempre paroquial, não faz sentido pensar uma moralidade internacional universalista para além de um corpo enxuto de valores, como a proibição do genocídio, do assassinato, da tortura e da escravidão. E o que sustentaria estes interditos seriam justificativas culturalmente situadas dispersas em diversos corpos de valores culturais diferentes. Walzer defende que a moralidade é "espessa" [thick] por definição, pois é integrada e coerente, revelando-se fina [thin] apenas em ocasiões especiais e urgentes, como as lutas contra a tirania, a limpeza étnica e o apartheid racial. A ideia de justiça, nas mais diversas sociedades, retira seus valores e argumentos de perspectivas e significados culturalmente partilhados e, não importa o que se diga sobre a moral, sempre fará parte de um todo cultural. Alguns aspectos desta totalidade especialmente os negativos, como a rejeição à brutalidade - serão imediatamente acessíveis a pessoas nascidas em outros universos culturais. E a soma destas parcelas de significados acessíveis a pessoas das mais diversas sociedades e sobre as quais pode haver consenso mundial é o que Walzer denomina "moralidade mínima" [minimal morality]. E esta moralidade mínima é interpretada de maneiras distintas a partir das diferentes "moralidades máximas" [maximal moralities] às quais os indivíduos são filiados e entres as quais há fortes desacordos normativos ${ }^{250}$, pois

Minimalism is neither objective nor unexpressive. It is reiteratively particularist and locally significant, intimately bound up with the maximal moralities created here and here and here, in specific times and places. ${ }^{251}$

Quando o minimalismo é expresso em uma moralidade mínima, sempre é pronunciado em idioma pertencente a uma moralidade máxima. Não existem linguagens morais neutras ou inexpressivas. Existem elementos de moralidades espessas que podem ser mobilizados de modo a angariar apoio de diferentes partes do mundo em torno de causas locais; como o fim da tirania e da ditadura entre os tchecos, que angariou simpatias em todo o mundo e é um exemplo que permeia todos os capítulos de

\footnotetext{
${ }^{250}$ Walzer, 1994, pp. 5-6.

${ }^{251}$ Walzer, 1994, p. 7.
} 
Thick and Thin. Moral argument at home and abroad. Para Walzer, é possível fazer uma lista de situações problemáticas locais e respostas internacionalmente compartilhadas e, daí, talvez, chegar a uma classe consensual de padrões morais que devem ser respeitados por todas as sociedades - injunções negativas, como regras contra o assassinato, a tortura, a opressão e a tirania. Entre norte-americanos e europeus, estes padrões mínimos pode ser expresso na linguagem dos direitos, que diz respeito a injúrias e violações pelas quais ninguém deveria passar e que faz parte de uma moralidade máxima particular e que, talvez, possa ser traduzida para outros idiomas morais espessos ${ }^{252}$.

Ainda segundo Walzer, este mínimo moralmente compartilhado não engloba o pluralismo cultural enquanto valor, pois a maior parte das pessoas nas mais diversas épocas não vê os "outros" em seus contextos particulares como portadores de valor moral intrínseco. O respeito ao pluralismo cultural é uma idéia pertencente a uma "moralidade máxima" [maximalist idea], produto de concepções políticas liberais espessas. O minimalismo depende de algo bem mais "fino": do fato de que nós temos expectativas morais a respeito do comportamento dos nossos compatriotas e dos habitantes de outros países; ao mesmo tempo, os "estrangeiros" possuem expectativas que se sobrepõem às nossas [overlapping expectations] com relação às suas próprias condutas e às daqueles que enxergam como "outros". Há compartilhamento de valores pelos quais vale a pena lutar e até intervir em outros países, mas o mínimo contido nestes valores não funda moralidades espessas. Os "encontros" entre pequenas parcelas das várias "moralidades máximas" existentes não são suficientes para sustentarem um entendimento global da justiça, já que estes “encontros” só são apreensíveis a partir de interpretações culturais paroquiais ${ }^{253}$.

Do mesmo modo, estes "encontros" são ainda mais distantes de formulações de igualdade e justiça de gênero, ao ponto de Walzer afirmar, em nome do caráter "espesso", culturalmente situado e socialmente construído da moral, que a crítica feminista às práticas culturais que afirmam que as mulheres devem subordinar seus destinos às escolhas de seus pais, irmãos e maridos não é normativamente legítima. Para ele, descartadas as possibilidades de lavagem cerebral e coerção pela força, não há

\footnotetext{
${ }^{252}$ Walzer, 1994, p. 10.

${ }^{253}$ Walzer, 1994, pp. 17-19.
} 
nenhuma maneira normativamente legítima de questionar afirmações sexistas realizadas por mulheres e a postura moralmente mais defensável é a proteção dos direitos destas mulheres a viverem de acordo com suas crenças sexistas ${ }^{254}$.

A partir de todas estas considerações sobre a natureza da moralidade como construto social e, portanto, paroquial e culturalmente situado, Walzer defende que não existe forma de reflexão normativa que permita o distanciamento de interesses, paixões e entendimentos compartilhados advindos do pertencimento social, fazendo questão de repetir que não existe "the view from nowhere" ${ }^{255}$. E deduz que, não sendo possível reflexão moral desconectada de entendimentos compartilhados, o único modo apropriado de argumentação moral é a interpretação dos significados sociais e culturais e que isso não nos prende a uma afirmação do status quo porque sempre há conflitos internos que dão origem a "criticismo social" ${ }^{256}$. Sendo que

Criticism does not require us to step back from society as a whole but only to step away from certain sorts of power relationships within society. It is not connection but authority and domination from which we must distance ourselves. Marginality is one way of establishing (or experiencing) this distance; certain sorts of internal withdrawal provide other ways. ${ }^{257}$

Segundo Walzer, a interpretação e o criticismo sociais devem ser sempre uma reflexão interna às comunidades que apele a significados sociais e culturais internos, sob pena de se praticar imperialismo moral e se desrespeitar o pertencimento comunitários e se imaginar aberrações como espectadores e críticos morais que são "a westernized and Anglophile Indian", "a Parisian Marxist who happens to be Algerian":

He has gone to school at the imperial center, at Paris or Oxford, say, and broken radically with his own parochialism. He would have preferred to stay at Paris or Oxford, but he has dutifully returned to his homeland so that he cab criticize the local arrangement. ${ }^{258}$

Toda esta descrição da argumentação universalista e do dever ser da "interpretação social" e do "criticismo social" são um tanto quanto caricaturais.

\footnotetext{
254 _. "Objectivity and Social Meaning." In SEN, Amartya \& Martha Nussbaum (org.). The Quality of Life. Oxford: Clarendon Press, 1993b., pp. 175-176.

${ }^{255}$ Alusão a Thomas Nagel.

${ }^{256}$ Walzer, 1993a.

${ }^{257}$ Walzer, 1993a, p. 60.

${ }^{258}$ Walzer, 1993a, p. 38.
} 
Nenhum defensor do universalismo e do pluralismo moral desconhece que estes são criações sociais paroquiais. E críticos da desigualdade e das relações de poder nas sociedades não-ocidentais não são indianos ocidentalizados e marxistas parisienses acidentalmente nascidos na Argélia. Como o próprio Walzer afirma, existe disputa de significado em todas as culturas e comunidades, não sendo lícito considerar que o universalismo, fora do ocidente, seja sempre uma crença fora de lugar e um valor importado dos países centrais.

Este modo de pensar a natureza da moralidade e o modo apropriado de argumentação moral leva Walzer a afirmar explicitamente que mulheres que expressam valores sexistas em que se auto-consideram objeto de troca entre os homens (pais, irmãos e maridos) e que seus destinos devem ser determinados por eles, descartadas as hipóteses de lavagem cerebral e coerção física, devem ter seu direito a integridade cultural garantido ${ }^{259}$.

Acredito que tudo isso torna muito questionável pensar a justiça social, a justiça global e a justiça de gênero apenas a partir dos significados compartilhados que podemos captar nas falas das pessoas culturalmente situadas, nos princípios morais que invocam, nas histórias que narram, nos textos fundacionais que defendem, nos rituais que praticam, nas retóricas públicas, nos comportamentos tradicionais que reproduzem etc.. Restringir-se a este modo de argumentação moral é renunciar à possibilidade de se defender normativamente um direito de saída efetivo para as mulheres sob forte condição de desigualdade de gênero. Para tratar disso, discutirei brevemente algumas considerações sobre cultura, diversidade cultural, sobre o "outro" não-ocidental e sobre os valores e "preferências sobre valores" expressos pelas pessoas e implícitos nas práticas e instituições culturais e comunitárias.

Heiner Bielefeldt ${ }^{260}$ e Amartya Sen ${ }^{261}$ lembram que o Ocidente inventou-se a si mesmo ao afirmar os direitos humanos como algo que embebe a cultura ocidental como um todo. Muitas correntes filosóficas e políticas inegavelmente ocidentais são contrárias

\footnotetext{
${ }^{259}$ Walzer, 1993b, pp. 175-176.

${ }^{260}$ BIELEFELDT, Heiner. "Western” versus "Islamic" Human Rights Conceptions?: A critique of cultural essentialism in the discussion on human rights." Political Theory, Vol. 28, No. 1, fev. de 2000, pp. 90-121. ${ }^{261}$ SEN, Amartya. Desenvolvimento como Liberdade. São Paulo: Companhia das Letras, 2001.
} 
às ideias de direitos humanos. Não há um Ocidente coeso defensor dos direitos individuais universais, dos direitos humanos e da igualdade de gênero. Também foi parte dessa invenção ocidental de si mesmo a invenção de um oriente, de uma África e de um islamismo essencialmente e coesamente sexistas e contrários aos direitos humanos. Bielefeldt cita vários exemplos de ideias fortemente contrárias aos direitos humanos e inegavelmente ocidentais que vêm desde a Antiguidade Grega ${ }^{262}$ e Sen faz o mesmo ${ }^{263}$. Ao mesmo tempo, Bielefeldt mostra vários exemplos de defesas islâmicas de ideias parecidas com as dos direitos humanos e que pregam a separação entre a cidadania política e as crenças privadas ${ }^{264}$. E Sen mostra exemplos de pensadores e políticos indianos que também professavam crenças que podem ser inventadas como precursoras do conceito de direitos humanos e do secularismo político ${ }^{265}$. Segundo Bielefeldt anuncia no próprio título de seu artigo, sua tese é a de que considerar os direitos humanos como ideias exclusivamente ocidentais e extremamente constitutivas da ocidentalidade em oposição ao mundo islâmico é uma essencialização da cultura destes dois mundos. Como afirma Sen

Valores que o Iluminismo europeu e outras tendências relativamente recentes tornaram comuns e disseminados não podem realmente ser considerados parte da herança ocidental no longo prazo - vivenciada no Ocidente no decorrer de milênios. O que efetivamente encontramos nos escritos de autores clássicos ocidentais específicos (por exemplo, Aristóteles) é a defesa de componentes selecionados da noção abrangente que constitui a ideia contemporânea de liberdade política. Mas a defesa desses componentes pode ser encontrada em muitos textos de tradição asiática ${ }^{266}$.

E, mais, adiante,

A defesa da ordem e da disciplina pode ser encontrada também nos clássicos ocidentais. Na verdade, para mim, não está nem um pouco claro se Confúcio teria sido mais autoritário a esse respeito do que, digamos, Platão ou Santo Agostinho. A verdadeira questão não é se essas perspectivas de ausência de liberdade estão presentes nas

\footnotetext{
262 Bielefeldt, 2000, pp. 94-97.

${ }^{263}$ Sen, 2001, pp. 220, 236.

264 Bielefeldt, 2000, pp. 102-114.

${ }^{265}$ Sen, 2001, pp. 220-114.

${ }^{266}$ Sen, 2001, p. 268.
} 
tradições asiáticas, mas se as perspectivas orientadas para a liberdade estão ausentes nessas tradições ${ }^{267}$.

E, como mostram Sen e Bielefeldt, indubitavelmente, elas não estão. A interpretação e o criticismo sociais a partir de significados compartilhados não pode se esquecer de que todo significado compartilhado também é um significado disputado e que muito do que pensamos sobre as diferenças culturais entre países ocidentais e nãoocidentais são invenções culturais ocidentais.

Outro ponto importante é que, no caso das violações graves de direitos humanos e de direitos das mulheres, é muito pouco provável que seu questionamento a partir de critérios de igualdade só possa ocorrer a partir de linguagens externas aos padrões morais locais.

Além disso, a força e disseminação ampla de práticas e instituições violadoras de direitos humanos e de direitos das mulheres não significa consentimento por parte das pessoas cujos direitos são violados. Como mostra Vita,

Teorias interpretacionistas se valem de uma noção de consentimento (a práticas, instituições e valores prevalecentes) excessivamente fraca para ter as implicações legitimadoras. ${ }^{268}$

E, como mostra Okin, a adoção majoritária de um significado e de um critério distributivo pode estar por demais conectada a relações de dominação e não ao consentimento. E, retomando Amartya Sen e Martha Nussbaum, o fato das mulheres pobres e em posições de subordinação forte afirmarem valores sexistas e expressarem preferências muito aquém de direitos e oportunidades defendidos pelas concepções universalistas de justiça podem ser apenas uma questão de preferências adaptativas ${ }^{269}$. Por exemplo, qual o significado de grande parte das mulheres indianas afirmarem que o que mais desejam para suas crianças são empregos e não acesso à escola? Como argumentam estes dois autores, é provável que estas mães expressem esta preferência apenas por conviverem com o medo cotidiano de que seus filhos não tenham acesso à alimentação suficiente. E qual seria o significado de uma mulher da periferia paulistana

\footnotetext{
${ }^{267}$ Sen, 2001, p. 269.

${ }^{268}$ Vita, 2008, p. 210.

${ }^{269}$ Sen, 2001 e Nussbaum, 2001.
} 
afirmar que seu maior desejo para os seus filhos é que não morram assassinados precocemente $?^{270} \mathrm{E}$ podemos deduzir do fato de que muitas moças africanas que não passaram pela mutilação genital e por isso têm dificuldades de se casar reivindicarem que deveriam ter sido mutiladas significa que a mutilação genital feminina não é uma violação de direitos e uma questão de desigualdade extrema e ilegítima?

Estas perguntas colocam em questão o valor das preferências que as pessoas expressam e a validade de métricas puramente subjetivistas (ou puramente welfaristas) de elaboração e avaliação normativa. Conforme argumentam $\operatorname{Sen}^{271}$ e Nussbaum ${ }^{272}$, métricas puramente subjetivistas podem levar à mera afirmação de valores, práticas e instituições que reflitam relações de poder prevalecentes e que expressem preferências adaptativas formuladas pelas pessoas pior posicionadas social e culturalmente.

Vita denomina este raciocínio de "argumento das pequenas mercês"273, o qual evidencia uma questão fundamental de justificação, a da relação entre valores, desejos e preferências. $\mathrm{O}$ fato de algo ser desejado intensamente não implica que seja valioso do ponto de vista da justiça. E o fato de que algo não seja expresso como desejo não significa que não seja um direito. Assim, retomando Sen,

Avaliar a vantagem individual de pessoas submetidas à destituição e à desigualdades profundas somente por seus desejos e preferências efetivos significa corroborar a injustiça de que são vítimas. ${ }^{274}$

Um outro ponto é que, como lembra Amy Gutmann, a suposição de que basta perceber os significados dos bens sociais que as pessoas afirmam e deles derivar critérios de justiça e direitos humanos negligencia o fato de que um mesmo bem social possui muitos significados diferentes dentro de um mesmo contexto cultural e comunitário e significados diferentes originam critérios distributivos diversos ${ }^{275}$. Isso também mostra que interpretar o significado de bens sociais e suas implicações distributivas não é suficiente para elaborarmos teorias normativas, pois também é

\footnotetext{
${ }^{270}$ Nenhum destes exemplos é hipotético. O primeiro aparece em surveys citados por Sen e Nussbaum. O segundo é uma afirmação recorrente da minha diarista, que tem quatro filhos homens adolescente e que teve dois sobrinhos de menos de 20 anos assassinados no início de 2009.

${ }^{271}$ Sem, 2001 e Sen 1995a.

272 Nussbaum, 2001.

${ }^{273}$ Vita, 2008, p. 95.

${ }^{274}$ Vita, 2008, pp. 95-96.

275 GUTMANN, Amy. "The Challenge of Multiculturalism in Political Ethics." Philosophy and Public Affairs, Vol. 22, No. 3, 1993, pp. 171-206.
} 
necessário pensar critérios para decidir entre significados sociais e implicações distributivas conflitantes.

Pois bem, dado que pensamos ser possível fundamentar e justificar posturas universalistas espessas a ponto de incluir alguma forma de igualdade de gênero cosmopolita entre os direitos de que são titulares todos os homens e mulheres do mundo, passemos a alguns modos de reflexão universalista sobre a justiça de gênero. 


\section{Aproximações preliminares a um equalisandum de gênero cosmopolita ${ }^{276}$}

Contornado o problema da "objeção neo-hegeliana" e da impossibilidade de se pensar critérios de moralidade internacional universalmente válidos e lembrando que estamos a procura de uma interpretação da estrutura básica e do que é moralmente arbitrário que permita acessar os aspectos coercitivos da cultura sem violar o pluralismo moral razoável, passemos a nosso esboço de proposta de justiça cosmopolita que dê conta do problema da desigualdade de gênero.

Os teóricos do liberalismo igualitário rawlsiano têm evitado usar seus critérios e princípios de justiça social para estabelecer comparações e exigências normativas transnacionais amplas e detalhadas a respeito de justiça, qualidade de vida e desigualdade de gênero, sexualidade e etnia ${ }^{277}$. Mas, como vimos, isso está sendo feito por autores de outras perspectivas normativas igualitárias, por exemplo, por Amartya Sen, Martha Nussbaum, o World Institute for Development Economic Research (WIDER) e demais defensores do enfoque das capacidades o fazem amplamente ${ }^{278} \mathrm{e}$ por Onora O’Neill ${ }^{279}$.

Sen e Nussbaum argumentam que as categorias de functioning e de capacidades abordam melhor a questão da igualdade e da liberdade e permitem comparações internacionais mais acuradas do que as métricas utilitaristas, de titularidades, dos recursos, dos "bens primários" rawlsianos etc. Repetindo resumidamente, functionings são estados e atividades valiosos, como estar adequadamente nutrido, estar livre de doença facilmente evitáveis, ser alfabetizado, estar livre de vergonha de aparecer em público etc. São ingredientes do bem-estar, sendo que as comparações interpessoais a respeito do bem-estar devem se basear na liberdade de alcançar bem-estar. E capacidade é o nível de liberdade efetiva de escolher entre diferentes tipos de vida, com diferentes combinações possíveis de functionings valiosas. Sen e Nussbaum defendem a

\footnotetext{
${ }^{276}$ Esta seção talvez seja a mais "preliminar" deste working paper e é mais uma declaração de intenções do que uma proposta normativa já consolidada.

${ }^{277}$ Suas comparações se referem mais a direitos humanos e à justiça distributiva do que a concepções globais de justiça comparáveis a suas concepções de justiça social.

${ }^{278}$ Sen (2000), Sen (1995) e Nussbaum (2001) dedicam-se longamente a comparações internacionais utilizando o enfoque das capacidades. E vários artigos reunidos em Sen \& Nussbaum (1993) e Nussbaum \& Glover (1995) são uma amostra desses esforços de comparação realizadas por outros autores.

${ }^{279}$ O'Neill, $2000 .^{2}$
} 
superioridade destas categorias para se estabelecer comparações sobre bem-estar e se avaliar situações de injustiça, pois estas duas categorias se referem a fruir e exercer liberdades, não a meios para se alcançar bem-estar e exercer liberdade ${ }^{280}$. Nas palavras de Sen, uma abordagem focada em recursos como é a dos "bens primários” é imprópria, pois

The behavioural constraints related to perceptions of legitimacy and correctness can strongly affect the relationship between primary goods and the freedoms that can be generated with their use. If women are restrained from using the primary goods within their command for generating appropriate capabilities, this disadvantage would not be observed in the space of primary goods. It is not clear how these constraints, many of which are implicit and socially attitudinal, can be incorporated within the framework of the 'external' category of primary goods ${ }^{281}$.

Isso mostra que o problema da métrica dos bens primários, na visão de Sen, está ligado ao que aqui foi defendido como componentes culturais que devem ser incorporados à interpretação da estrutura básica e que podem incluir instituições como família e igreja e expectativas de padrões comportamentais orientados por gênero que são impressos no funcionamento das diversas instituições formais e informais.

Constrangimentos culturais e heterogeneidades pessoais e ambientais que fazem com que os mesmos recursos sejam transformados em diferentes exercícios de liberdades substantivas são especialmente importantes se queremos nos endereçar cosmopolitamente às liberdades e bem-estar de todas as mulheres do mundo, sendo assim, não podemos negligenciar esta crítica em particular. Façamos um parênteses de resposta recursista rawlsiana à crítica de Sen à métrica dos bens primários.

\footnotetext{
280 Sen, 1995

${ }^{281}$ Sen, 1995, p. 265.
} 


\section{1. A resposta recursista e rawlsiana de Pogge ao enfoque das capacidades}

Sen afirma que as capacidades são um espaço avaliatório sensível a determinantes de desigualdade que não são acessados por abordagens recursistas. Vejamo-os.

1. A afirmação de Sem e Nussbaum de que enfoques recursistas não dão conta do problema das distribuições intrafamiliares anti-igualitárias: os critérios de avaliação da justiça social individualistas são todos aptos para acessar a questão da distribuição intrafamiliar independentemente de sua métrica (bem-estar, recursos, capacidade etc.) e de serem igualitários, prioritaristas ou suficientaristas. O que torna uma concepção de justiça incapaz de lidar com a questão da justiça intrafamiliar é avaliar de modo agregado em vez de realizar comparações interpessoais (individualistas). Nisso, a abordagem das capacidades e dos bens primários são iguais. Mas Sen pode estar certo ao dizer que o enfoque das capacidades é mais apto para medir os vieses intrafamiliares de gênero através de comparações entre mortalidade, alfabetização etc. entre homens e mulheres. Mas isso mostra melhor aptidão para se evidenciar a injustiça distributiva intrafamiliar e não uma melhor concepção de justiça social. $^{282}$

2. A afirmação de Sen e Nussbaum de que abordagens recursistas não são capazes de lidar com diferenças de perspectiva relacional ["differences in relational perspective"]: comunidades diferentes exigem bens diferentes e em quantias diferentes para que as pessoas alcancem funcionamentos valiosos. Uma mesma quantia de dinheiro proporciona possibilidades de vida muito diferentes em países diferentes (nos EUA ou na Índia, por exemplo) e sociedades diversas exigem roupas, alimentação etc. diversos. O valor relativo dos bens pode ser bem (ou mal) captados tanto por abordagens recursistas quanto de capacidades. E os dois enfoques podem lidar adequadamente com o fato de que os bens possuem valor absoluto e valor relativo. E as abordagens recursistas não são necessariamente insensíveis ao fato de que o valor do que uma pessoa possui tem relação com aquilo que as pessoas a sua volta possuem (isso

\footnotetext{
${ }^{282}$ Pogge, 2001, p. 19.
} 
não é válido apenas para renda e riqueza, mas para educação, empregos, saúde, lazer etc.). ${ }^{283}$

3. A afirmação de Sen e Nussbaum de que enfoques recursistas não são capazes de lidar com variações no clima social: a conversão de bens e qualidade de vida depende de condições sociais como segurança, poluição, relações comunitárias, políticas públicas disponíveis etc. Uma abordagem recursista sofisticada pode dar conta destas variações e do fato de que as condições sociais possuem impactos diferentes para pessoas e grupos distintos. ${ }^{284}$

4. A afirmação de Sen e Nussbaum de que enfoques recursistas não são capazes de lidar com diversidades ambientais: o clima, a presença de epidemias e outras variações entre países e regiões causam necessidades diferentes e isso pode ser acessado tanto pelos enfoques recursistas quanto pelos de capacidades, ainda que as abordagens recursistas ainda não tenham trabalhado detidamente sobre o problema das diversidades geográficas. ${ }^{285}$

5. A afirmação de Sen e Nussbaum de que enfoques recursistas não são capazes de lidar com heterogeneidades interpessoais: pessoa possuem dotes e necessidades (físicas e mentais) diversas. O modo como estas heterogeneidades devem ser tratadas está no cerne da controvérsia respeito de recursos e capacidades. Os recursistas trabalham com concepções de necessidades e dotações padrão para pensar a seleção e distribuição de bens. Os teóricos das capacidades pensam o valor dos bens e a sua distribuição a partir das necessidades e dotes específicos das pessoas. Neste sentido, o enfoque das capacidades é mais sensível às heterogeneidades interpessoais, mas Sen sobrevaloriza esta diferença ao acusar os recursistas de não darem a devida atenção a heterogeneidades para as quais eles estão atentos. ${ }^{286}$

5.1. Sen e Nussbaum exemplificam o problema das heterogeneidades interpessoais afirmando que a abordagem recursista não é capaz de lidar com as diferenças de gênero:

\footnotetext{
283 Pogge, 2011, pp. 19-20.

284 Pogge, 20122, pp. 22-23.

285 Pogge, 2011, pp. 22-23.

${ }^{286}$ Pogge, 2011, p. 23.
} 
It is possible to formulate a resourcist criterion of social justice that, in selecting, formulating, and weighting valuable resources, takes full account of any divergences in the needs of males and females and also is appropriately sensitive to covert forms of discrimination by assessing any institutional order by how it actually works in its social and natural context. Such a resourcist criterion would employ an unbiased conception of the standard needs and endowments of human beings and would count an institutional order as just only if it secured genuinely equal treatment to its female and male participants. On the other hand, it is also easily possible to formulate a male-centered capability view that bases its selection, formulation, and weighting of valuable capabilities on the standard needs of males and also is insensitive to covert forms of discrimination by analyzing any institutional order without attention to the possibly quite sexist culture within which it is operating. ${ }^{287}$

5.2. Sen afirma que a abordagem recursista não é capaz de lidar com as necessidades das diferentes faixas etárias. Os dois enfoques - recursista e de capacidades - devem considerar que as pessoas possuem uma vida normal completa, passando por todas as idades e que as necessidades e dotes variam conforme a idade. Sendo assim, não é anti-igualitário pensar em tratamentos desiguais a uma mesma pessoa ao longo de toda a sua vida (crianças possuem creches, mas adultos não; idosos recebem aposentadoria, enquanto jovens pagam a previdência etc.), desde que todas as pessoas vejam suas necessidades contempladas em todas as fases de sua vida. Isso vale para ambas as abordagens. ${ }^{288}$

5.3. Pessoas variam em seus corpos e mentes, possuindo diferentes possibilidades de conversão de recursos em funcionamentos valiosos, mas os recursistas também podem lidar com isso. O corpo e a mente são moldados por aspectos sociais e culturais (como acesso à nutrição, saúde, educação, ambiente familiar etc.) e os recursistas podem lidar com o fato de que o acesso a recursos na infância e juventude melhora as disposições físicas e mentais e a possibilidade de transformar recursos em funcionamentos valiosos na maturidade e velhice e de desfrutar das oportunidades de participação social e política, por exemplo. As capacidades das pessoas transformarem

\footnotetext{
${ }^{287}$ Pogge, 2001, pp. 25-26.

${ }^{288}$ Pogge, 2011, pp. 26-28.
} 
recursos em funcionamentos dependem dos recursos que receberam em fases anteriores de suas vidas. ${ }^{289}$ Assim, segundo Thomas Pogge

Resourcist views have every reason to take account of interpersonal differences insofar as these are due - as in fact they overwhelmingly are in the world at large - to past inequalities in the resource access persons had under their institutional order. Nearly all persons with special mental or physical needs or disabilities today would be perfectly capable of leading happy and healthy lives if they were not suffering the effects of severe past (and present) resource deprivation: lack of effective civil and political rights and inadequate access to water, food, shelter, health care, and education. Insofar as such resource deprivation was unjust, a just institutional order will compensate for its effects. The members of a society or other social system have a duty of justice to mitigate the harms caused by their prior wrongdoing. These problems are addressed more compellingly by resourcists than by capability theorists. Where the latter criticize institutional schemes for their failure to compensate for special physical and mental frailties, resourcists more powerfully criticize the same institutional schemes for their failure to compensate for frailties they themselves produce through the severe mistreatment they impose on so many children and adults. This criticism is closely linked with another: The reform of such institutional schemes must not merely ensure that they compensate for frailties they had produced in the past (insofar as doing so is still reasonably possible), but also that they no longer produce and reinforce such frailties. This last point is crucial: In order to count as just, an institutional order must not merely repair, and compensate for, the effects that deprivations it inflicts have on the physical and mental constitution of its participants - which all too often cannot be done fully or even at all. It must also and most importantly avoid causing such damage in the first place insofar as this is reasonably possible. ${ }^{290}$

Heterogeneidades interpessoais causadas independentemente dos arranjos sociais serem justos ou injustos - como ser atingido por um acidente de trânsito também devem ser reparadas pelos arranjos institucionais.

5.4. A abordagem recursista pode ser excessivamente sensível à causa das necessidades especiais (se possui componente social ou não, se é auto-causada ou se é fruto de um evento aleatório como ser atingido por um raio [differential luck]). Adeptos da abordagem recursista podem responder a este perigo dizendo que raramente uma

\footnotetext{
289 Pogge, 2011, p. 28.

290 Pogge, 2011, p. 29.
} 
necessidade não possui causa social, cultural ou institucional. Assim, uma abordagem recursista pode ser superior em seu modo de apresentar justificativas, pois compensa as necessidades especiais por reconhecer o papel social em sua criação e perpetuação e não por reconhecer que algumas pessoas são mais necessitadas simplesmente, como se isso fosse de sua própria constituição (e não de constituição social), de modo a possibilitar estigma. A causalidade/responsabilidade social pelas necessidades em geral e pelas necessidades especiais faz com que sejam necessários "all-purpose means" que sejam abstratos o suficiente para dar conta do maior rol possível de necessidades e dotes, de modo a construir tratamento igual genuíno. As eventuais necessidades especiais cuja origem não se relaciona com a virtude da justiça podem, mesmo assim, ser aliviadas através de outras virtudes morais, como deveres de solidariedade para com todos aqueles com que partilhamos vida comum e deveres de humanidade para com todos os seres humanos. $^{291}$

\section{2. Bens primários cosmopolitas e direito de saída pleno}

Contornadas as críticas de que os enfoques recursistas, entre os quais o dos bens primários, não seriam capazes de lidar com heterogeneidades pessoais e ambientais que são amplas e profundas em escala mundial, voltemos ao problema de que lidar com aspectos claramente culturais e informais das instituições da estrutura básica, que não fazem parte da coerção estatal (mas são profundamente coercitivos), não pode ser violador do pluralismo moral razoável. Uma lista de capacidades humanas centrais como a proposta por Nussbaum é demasiado atrelada a noções de bem e de vida verdadeiramente humana e pode ser pouco adequada em uma realidade de pluralismo moral profundo e uma forma de liberalismo abrangente, de modo a poder ser objeto da crítica de David Miller segundo a qual o igualitarismo global pensa os equalisanda de modo excessivamente paroquial, por avaliar a equidade de oportunidades a partir de entendimentos culturais situados em poucos países e compatíveis com poucas concepções de bem.

${ }^{291}$ Pogge, 2011, pp. 31-33. 
Para pensarmos um tipo de igualitarismo conforme um liberalismo político (e não abrangente), precisamos encontrar um equalisandum que proporcione oportunidades equitativas para cada um exercer sua própria concepção de bem dentro dos limites do razoável. E este equalisandum deve se aplicar sobre um "objeto da justiça" que seja capaz de lidar com as relações de poder e coerção denunciadas sob o slogan feminista de que "o pessoal é político". De modo a possibilitar uma regulação adequada destas relações de poder e coerção que borram as determinações mútuas entre o que é estatal e o que não é, entre instituições formais e informais, entre esfera pública e a privada, entre os âmbitos de justiça local, social e cosmopolita. Tudo isso sem desconsiderar o fato do pluralismo moral e as relações entre as circunstâncias subjetivas e objetivas da justiça e que o valor equitativo das liberdades passa pela relação adequada e indivisível entre direitos civis, políticos, sociais e econômicos. A disputa entre o enfoque das capacidades, particularmente na versão de Women and Human Development, e a métrica dos bens primários é fortemente vinculada a isso, afinal, ambas as abordagens acessam diferentemente a relação entre coerções formais e informais, entre público e privado a partir de seus diferentes equalisanda.

Em Rawls, o equalisandum defendido para o âmbito doméstico das sociedades liberais é diverso do proposto para o plano internacional, que, em relação aos indivíduos, inclui apenas uma concepção minimalista direitos humanos como classe especial de direitos urgentes ${ }^{292}$ e a igualdade que realmente importa é a igualdade entre povos, não entre indivíduos.

No plano doméstico, seu equalisandum gira em torno do que permite a satisfação dos dois princípios de justiça da "justiça como equidade", que prescrevem que:

a. Cada pessoa tem um direito igual a um sistema plenamente adequado de direitos e liberdades iguais, sistema esse que deve ser compatível como um sistema similar para todos. E, neste sistema, as liberdades política, e somente estas liberdades, devem ter seu valor equitativo garantido.

b. As desigualdades sociais e econômicas devem satisfazer duas exigências: em primeiro lugar, devem estar vinculadas a posições e cargos abertos a todos em condições de igualdade equitativa de

${ }^{292}$ Rawls, 2001. Esta concepção de direitos humanos é tomada de Shue (1996). 
oportunidades; em segundo lugar, devem se estabelecer para o maior benefício possível dos membros menos privilegiados da sociedade" ${ }^{\# 2}$.

Aquilo de que os cidadãos precisam e podem exigir publicamente em nome destes dois princípios são os bens primários, cuja lista básica (mas não exclusiva) pode ser dividida nas seguintes categorias:

a. os direitos e liberdades fundamentais, também especificados por uma lista;

b. liberdade de movimento e livre escolha de ocupação, contra um contexto de oportunidades diversificadas;

c. capacidades e prerrogativas de cargos e posições de responsabilidade nas instituições políticas e econômicas da estrutura básica;

d. renda e riqueza;

e. e, por fim, as bases sociais do autorrespeito. ${ }^{294}$

Esta lista é formulada por Rawls para o plano interno às sociedade liberais, mas, do ponto de vista do cosmopolitismo feminista, parece adequada também para o plano cosmopolita. A partir dela, vemos que os bens primários são sim meios de se alcançar liberdades e bem-estar, como afirma Sen. Mas também possuem valor intrínseco, sendo eles próprios liberdade no sentido que o próprio Amartya Sen dá às liberdades em sua teoria sobre o "desenvolvimento como liberdade" 295 . Além disso, os bens primários possuem a virtude de serem aplicáveis à estrutura básica através de normas que podem ser implementadas pelos Estados e que são conforme a noção de que os "meios da justiça" são instituições formais conforme as condições rawlsianas de publicidade.

Há um outro sentido importante normativamente em que os bens primários são conforme a publicidade: conforme mostra Pogge, eles são um equalisandum capaz de ser justificado a partir da igualdade moral inerente às pessoas, não sendo formulados com base em desigualdades de necessidade e vulnerabilidade. Eles são parte de um sistema normativo em que necessidades e vulnerabilidades especiais são criadas pela própria estrutura básica e que, portanto, não são inerentes às pessoas, mas à própria

\footnotetext{
${ }^{293}$ Rawls, 2011, p. 6.

294 Rawls, 2011, p. 213.

${ }^{295}$ Sen, 2001.
} 
injustiça social. Há muito potencial feminista nesta afirmação, pois aponta que as vulnerabilidades e necessidades especiais das mulheres são devidas à sociedade e não à natureza feminina. Por ser passível de justificação a partir da igualdade das pessoas e não de suas diferenças, o enfoque dos bens primários é mais capaz de "justificação pública.",296

Por serem aplicáveis através de "meios institucionais de justiça" e aplicáveis às instituições da estrutura básica da sociedade, permitem que os indivíduos não precisem endossar e atualizar crenças igualitárias em cada uma de suas ações e interações, o que torna a justiça como equidade menos demandante frente às posturas éticas dos indivíduos do que as propostas de objeto de justiça defendidas por Gerald Cohen e, portanto, menos invasivas perante as doutrinas de bem, ainda que as restrinjam aos limites da razoabilidade ${ }^{297}$. Isso é muito adequado para se pensar o cosmopolitismo, que inclui um pluralismo moral mais vasto do que o existente internamente a cada país, especialmente no que se refere a uma questão culturalmente tão enraizada e controversa quanto as relações de gênero.

Um equalisandum como os bens primários - mesmo estes sendo portadores de liberdades valiosas em si - por ser um equalisandum formado por recursos para se alcançar liberdade e bem-estar, permite uma relação com o pluralismo moral na qual o que se idealiza não é que as pessoas de todo o mundo tenham equitativamente as mesmas oportunidades, o que, segundo David Miller, seria questionável normativamente, pois as oportunidades, liberdades e bem-estar são avaliados pelas pessoas a partir de seus entendimentos e pertencimentos culturais e coletivos ${ }^{298}$. O que se prescreve a partir de uma lista de bens primários cosmopolita é que haja oportunidades equitativas de se exercer sua concepção de bem dentro dos limites do razoável. Isso porque os bens primários são liberdades e recursos valiosos para a realização de todas as concepções de bem razoáveis.

Sen critica os bens primários como forma de se acessar e implementar a igualdade de gênero, alegando que os mesmos bens primários representam quinhões de

\footnotetext{
296 Pogge, 2011.

297 Pois impedem que os Estados sejam utilizados em nome da preservação ou disseminação de doutrinas abrangentes do bem.

${ }^{298}$ MILLER, David. “Against Global Egalitarianism”. The Journal of Ethics Vol. 9, no. 1/2, "Current Debates in Global Justice", 2005, pp. 55-79.
} 
liberdade diferentes para homens e mulheres, dadas as suas diferenças biológicas e às diferentes expectativas sociais quanto aos papéis de gênero ${ }^{299}$ e Martha Nussbaum segue o mesmo raciocínio. No entanto, os bens primários são extensos o suficiente para permitirem que as mulheres possam exercer "direito de saída", se assim o desejarem, afinal, eles são uma combinação que permite que aspectos perversos das relações entre “(1) violações de direitos civis, políticos e socioeconômicos”, “(2) esfera pública e privada" e "(3) individualidade e coletividade" não se reforcem de modo a recrudescer a desigualdade e injustiça de gênero. Também possibilitam que estas três relações sejam reguladas de modo que justiça local, social e cosmopolita sejam compatibilizadas e que se vislumbre um direito de saída pleno.

Em uma aproximação preliminar a uma lista de bens primários cosmopolitas, podemos pensar que ela reproduz a lista formulada por Rawls para o plano interno às sociedades democráticas, pois, juntos, estes bens primários são recursos e valores em si e se relacionam com o local, o social e o cosmopolita em torno da própria noção de um espaço de inviolabilidade individual fundado na justiça, afinal, requerem valores básicos como liberdades civis, liberdades políticas e renda e riqueza num sistema de "liberdade efetiva" (conforme a liberdade efetiva exposta no conceito de liberalismo igualitário utilizado nesta tese).

Ainda num nível preliminar, podemos pensar que todos os âmbitos da justiça (local, social e cosmopolita) devem respeitar regras legais que fazem parte da estrutura básica enquanto "objeto da justiça" e enquanto "meio para a justiça". Que estas regras se expressam na própria lista de bens primários acima e visam implementá-la de modo a formar o próprio "espaço de inviolabilidade individual fundado na justiça" e o direito de saída em relação a todas as instituições e relações "institucionalmente instituídas" de que alguém queira se apartar - seja o casamento, a família, a igreja, a comunidade cultural, o país etc. Assim, princípios de justiça e bens primários expressos através dos "meios institucionais para a justiça" devem ser um todo integrado que inclua, entre outras regras,

(1) regras de orientação da conduta individual (como as que nos obrigam a respeitar a integridade física alheia, por exemplo);

${ }^{299}$ Sen, 1995. 
(2) regras de imposição legal da razoabilidade para as instituições e associações não coercitivas estatais, de modo que estas funcionem como associações em que o pertencimento é voluntário (como regras que obriguem à aceitação da apostasia);

(3) regras que estabeleçam condutas econômicas e de mercado que possibilitem maior proximidade do exercício efetivo das liberdades e do valor equitativo das liberdades (como direitos trabalhistas, saúde pública, educação pública, sistema tributário etc.);

(4) regras tributárias que aumentem a justiça distributiva;

(5) segurança pública capaz de atender às exigências das liberdades civis;

(6) saúde e educação públicas que permitam liberdades básicas efetivas et.

Todos os exemplos acima são modos públicos e institucionais de incidir sobre o privado e sobre o que é informal e cultural, propiciando uma relação tolerante entre público e privado e entre universal e particular e um modo adequado de pensarmos o direito de saída pleno.

Todos os exemplos acima constituem "justiça institucional" e "meios institucionais para a justiça” e implementam capacidades e o valor intrínseco e instrumental dos bens primários. Mas uma das vantagens do equalisandum bens primários é que eles próprios são institucionalmente expressáveis, segundo as próprias condições de publicidade do conceito de instituições rawlsiano e do conceito de justiça de Rawls.

Além disso, os "bens primários" são compatíveis com poderosas releituras do imperativo categórico kantiano: o princípio liberal de legitimidade rawlsiano e a proposta de Onora O’Neill.

O "princípio de legitimidade liberal” foi formulado por Rawls para o âmbito doméstico em Uma Teoria da Justiça. De acordo com este princípio, o exercício do poder político só é plenamente justificado quando exercido em consonância com princípios de justiça que se pode esperar razoavelmente que fossem aceitos por todos os que vivem sob eles, inclusive os que se situam nas piores posições da "estrutura básica 
da sociedade," ${ }^{300}$ o que dá conta do posicionamento social das mulheres que almejam exercer direito de saída de relações familiares e profissionais que considerem opressivas. Isso porque este "princípio liberal de legitimidade" exige normativamente que as concepções de justiça sejam aceitáveis por parte (1) daqueles que se encontram em uma minoria cujas convicções religiosas, políticas, morais ou de outro tipo divergem daquelas da maioria e (2) daqueles que possuem convicções excêntricas dentro do grupo minoritário ou majoritário em que nasceram. Neste trabalho, supõe-se que o "princípio liberal de legitimidade" também é aplicável à justiça global e ao questionamento das injustiças existentes na desigualdade gênero, o que significa que devemos pensar na aceitabilidade das diversas interpretações da justiça e dos direitos humanos para os indivíduos pior posicionados na estrutura básica global, sendo que o que torna estas posições menos favorecidas em relação a outras podem ser motivos religiosos, culturais, nacionais, políticos, étnicos, socioeconômicos, de gênero e sexualidade etc. e podem ocorrer em conjunto ou separadamente.

Por fim, os bens primários conseguem passar pelo teste proposto por Onora O’Neill, para quem as argumentações morais devem ser capazes de exercer a ideia kantiana do imperativo categórico de modo que os princípios de justiça sejam passíveis de aceitação por todos os membros de quaisquer pluralidades de seres entre os quais haja interação potencial ${ }^{301}$, o que inclui os âmbitos da justiça local, social e cosmopolita. Este teste é importante porque, mais uma vez, coloca a necessidade da aceitabilidade universal dos princípios de justiça, o que contempla homens e mulheres razoáveis e todas as pessoas morais imagináveis ${ }^{302}$.

Estas releituras do imperativo categórico podem ser aplicadas aos planos local, social e cosmopolita de justiça de um modo que respeita o axioma da igualdade moral humana e os articula em prol de um "direito de saída pleno" frente a todas as relações possíveis entre as diversas pessoas morais.

Assim, o que se propõe é um cosmopolitismo kantiano, isto é, um cosmopolitismo que justifique e relacione as três esferas de justiça (local, social e cosmopolita) em respeito ao axioma da igualdade moral e que constitua uma afirmação

\footnotetext{
${ }^{300}$ Este conceito será trabalhado adiante.

${ }^{301}$ O'Neill, 2000, p. 158.

302 Pessoas morais, em vocabulário kantiano, são pessoas jurídicas, o que não inclui apenas indivíduos, mas também Estados, empresas, ONGs etc.
} 
da prioridade da liberdade igual para todos (homens e mulheres), o que exige um "direito de saída pleno" frente a todas as relações possíveis entre todos os tipos de pessoas morais (individuais e coletivas). E, preliminarmente, podemos considerar que este direito de saída pleno pode ser realizado por um lista de bens primários cosmopolitas que reproduza a lista elaborada por Rawls para o plano interno. 


\section{Considerações Finais}

Estas considerações finais deter-se-ão sinteticamente sobre as propostas específicas desta tese, tributárias principalmente dos trabalhos de John Rawls, Susan Okin, Martha Nussbaum, Gerald Cohen. Apesar desta tese ter mobilizado muitos outros autores, creio que estes são os principais formuladores dos problemas normativos que esta tese enfrenta e também os principais formuladores do que permite respondê-las.

Sinteticamente, podemos considerar que esta tese investiga a possibilidade de uma proposta normativa feminista de justiça cosmopolita, questão esta que atravessa teoricamente as delimitações usuais entre os escopos da justiça local, social e global e das esferas pública e privada através da questão feminista liberal que nos termos de Okin indaga "how just gender?"

Relações de gênero são uma construção social ubíqua, não há manifestação humana que não seja permeada por elas. Gênero atravessa a distinção entre público e privado, ao ser construído em todas as áreas da vida humana: política, jurídica, econômica, social, religiosa, cultural, escolar, familiar etc. Ou seja, dada a sua ubiquidade, as relações de gênero são publica e privadamente construídas. Daí a importância e a dificuldade teórica da indagação "quão justo é o gênero?" e as exigências teóricas advindas do reconhecimento de que "o pessoal é político".

A defesa feminista dos poderes privados como questão política e de justiça deram origem a um debate profícuo que se alastrou pelas mais diversas vertentes normativas - liberalismo, republicanismo, multiculturalismo, comunitarismo, póscolonialismo etc. - gerando reformulações conceituais e ideais significativas que incidem sobre pensamento a respeito da democracia e da justiça social, especialmente em relação ao problema da religião e da família na constituição das identidades pessoais e da construção da desigualdade de gênero e da violações de liberdades das mulheres. Esta tese não seria possível se não bebesse desta fonte.

Martha Nussbaum levou este alastramento adiante ao construir uma proposta de feminismo internacionalista, defendendo princípios em prol de liberdades para as 
mulheres em todos os países do mundo dentro de uma perspectiva liberal e do enfoque das capacidades.

É na esteira de todas estas contribuições que esta tese se situa. Tomando o axioma da igualdade moral humana como afirmação da dignidade humana igual para homens e mulheres e a desigualdade de gênero como uma arbitrariedade moral, como fazem Susan Okin e Martha Nussbaum. Investigando as consequências de se pensar os poderes que constroem o gênero e são construídos por ele como parte do objeto da justiça entendida rawlsianamente como "um espaço de inviolabilidade individual igual". E pensando no universalismo cosmopolita decorrente da afirmação da igual dignidade individual de homens e mulheres para além de poderes privados e públicos e para além das fronteiras estatais, dentro de uma concepção em que todos os poderes devem ser justificados, em vez de terem sua legitimidade pressuposta. Isso constitui um universalismo pleno, para o qual, rawlsianamente, não existe esfera privada ou pública isenta de justiça e, pós-rawlsianamente, não há Estado cuja soberania possa ser justificada independentemente do individualismo ético - conforme a proposta de Rawls em seu Direito dos Povos. Assim, a perspectiva feminista internacionalista aqui proposta, seguindo Nussbaum, atinge (1) o "local", com suas famílias, religiões, culturas e associações, (2) o "social" de cada Estado e (3) o global. O que nos coloca diante do problema do monismo e do pluralismo morais.

Um dos principais méritos feministas de Nussbaum é, sem dúvida, atrever-se teoricamente a propor um internacionalismo feminista que funde estes três horizontes normativos em nome da liberdade e da não-violação das mulheres. Nenhum outro teórico questionou estas fronteiras normativas de modo tão completo antes. E ela o fez através de capacidades constitucionalizáveis que se pretendem válidos para todos os países e que permitiriam direito de saída para as mulheres que se sentissem em situação de opressão, numa proposta de escolha genuína liberal, compatível tanto com ideais de autonomia, quanto de modéstia feminina. Assim, o projeto de Nussbaum pretende-se uma afirmação normativa do feminismo, do liberalismo, do universalismo, do monismo, da tolerância individualista às diversas concepções de bem e do enfoque das capacidades, num diálogo direto com as mais diversas teorias e questões normativas. Esta tese não seria possível sem este esforço seminal que a precede. 
Do mesmo modo que esta tese e o trabalho de Nussbaum não seriam possíveis se não partissem do esforço feminista de investigação a respeito do pessoal ser político e da liberdade e justiça própria às relações de gênero. Da mesma maneira que a afirmação feminista da igual dignidade de mulheres e homens parte da afirmação iluminista da igualdade moral humana. E assim como a afirmação do gênero como questão de justiça parte da afirmação que pode ser socialista, marxista ou liberal-igualitária de que os poderes privados - como o poder da economia e do mercado - incidem sobre a liberdade tanto quanto os poderes políticos. E esta tese parte de tudo isso guiada pelos trabalhos seminais de Susan Okin, uma das primeiras teóricas a afirmar um feminismo liberal e que o liberalismo traz em si os germes do universalismo feminista e que o liberalismo rawlsiano permite acessar o problema da família, da religião e da cultura, com os devidos ajustes feministas, como

- $\quad$ a radicalização da posição original;

- o entendimento do gênero como arbitrariedade moral;

- o estabelecimento explícito e inequívoco da família como locus de poder e parte da estrutura básica da sociedade e objeto da justiça;

- o aprofundamento da teorização normativa da família como lugar de aprendizado do senso de justiça e sem a qual não há estabilidade normativa da justiça;

- e o esclarecimento da relação entre liberalismo político, doutrinas abrangentes e razoabilidade com as coerções do gênero através da religião, das concepções de bem e da cultura.

Os pontos acima são indispensáveis à construção do edifício argumentativo da proposta rawlsiana de cosmopolitismo feminista que defendemos como alternativa ao internacionalismo feminista de Nussbaum, tanto por esclarecer as críticas ao projeto de Nussbaum, quanto pelas possibilidades de propostas alternativas rawlsianas que abre.

$\mathrm{O}$ debate entre o enfoque das capacidades e o enfoque recursista rawlsiano compõe uma das clivagens que organizam o debate normativo contemporâneo e, por si só, isso torna relevante o cotejamento entre ambos os enfoques a partir da problemática feminista e da cosmopolita. A análise normativa de Women and Human Development- 
A capabilities approach the Martha Nussbaum permite que façamos ambos simultaneamente.

E fazê-lo a partir de Nussbaum e Okin permite que contemplemos muitas das principais questões propostas pelo feminismo. Pois Justice, Gender, and the Family de Okin discute criticamente as principais vertentes normativas contemporâneas de um ponto de vista feminista - liberalismo, liberalismo rawlsiano, libertarianismo, multiculturalismo e defesas das tradições e perfeccionismos ocidentais - passando pelos problemas da fundamentação e justificação normativas, da família, do casamento, da religião, da cultura e da dicotomia público/privado. O que é complementado por esta autora em inúmeros artigos. Ao passo que Nussbaum, que também escreveu inúmeros artigos sobre as mais diversas tradições normativas, em Women and Human Development, trata detidamente, em capítulos separados, da justificação do universalismo e do feminismo, das defesa do enfoque das capacidades em comparação ao enfoque dos bens primários, da questão do subjetivismo e objetivismo e das preferências e escolhas das mulheres, do papel da religião e da família. Assim, ambas as autoras percorrem um amplo espectro teórico e normativo e nos permitem a composição de um liberalismo feminista robusto, dentro de uma perspectiva liberal igualitária assumidamente rawlsiana, sendo talvez este o autor mais central para o feminismo aqui defendido.

Assim, como não poderia deixar de ser, menciono brevemente que, como deve ter ficado evidente ao longo do texto, assumimos e defendemos aqui um modo rawlsiano de interpretar o axioma da igualdade moral fundamental, seus métodos de argumentação moral formal e informal, sua concepção de liberalismo e de justiça, seu recursismo, sua concepção de estrutura básica como objeto primário da justiça e de justiça institucional etc.

Ditas brevemente as contribuições positivas destes três autores centrais, passemos ao modo como a articulação teórica entre seus argumentos e obras nos possibilitam críticas e ajustes mútuos feministas e cosmopolitas entre eles.

Novamente, comecemos por Nussbaum. Uma primeira crítica a ela aqui formulada endereça-se à sua compreensão de seu próprio liberalismo como uma "liberalismo político" em termos rawlsiano. Conforme argumentamos, seu liberalismo 
possui componentes aristotélicos e marxistas que compõem uma concepção de escolha genuína que, aliada à sua lista de capacidades, compõem um "liberalismo abrangente" e, longe de ser menos do que um ideal de justiça, como supõe a autora, compõem o que poderíamos chamar rawlsianamente de um ideal social abrangente que está muito além da prioridade da justiça própria do kantismo rawlsiano e que não poderia ser considerado como uma expressão do "domínio do político" - vide, por exemplo, a composição de uma lista de capacidades cosmopolitas.

O internacionalismo feminista precisa lidar com o pluralismo moral em sua escala mais ampla e intensa, tanto porque inclui todo o globo, quanto por incluir a família, a religião, comunidades culturais e demais entidades frequentemente vistas como pertencentes ao âmbito do privado e da justiça local. Por lidar com o pluralismo moral em seu ponto culminante, o cosmopolitismo feminista deve ser liberal em seu respeito normativo à prioridade da justiça sobre as concepções de bem e em sua capacidade de obedecer a critérios de justificação pública que unam o igualitarismo como igual consideração na justificação e como igual tratamento institucional através de um equalisandum capaz de passar em testes de justificação pública, universalista e conforme o individualismo ético. Entendendo aqui justificação pública ao modo de Pogge, para quem um equalisandum não deve ser defendido pelo fato das pessoas serem diferentes entre si e algumas necessitarem de tratamento diferente para atingirem a mesma liberdade e bem-estar - justificativa baseada na desigualdade entre as pessoas -, mas através da afirmação da igualdade moral entre mulheres e homens, entre pessoas de etnias distintas, entre indivíduos de diversos credos, entre pessoas nascidas em países diferentes etc. Enfatizando que as pessoas são iguais e que suas preferências e necessidades foram socialmente construídas pelas coerções da estrutura básica da sociedade - e, acrescentaríamos, pelas coerções formais e informais que, juntas, constituem a ubiquidade da coerção de gênero - de maneira que a diversidade de preferências e necessidades não é fonte de valor moral, mas uma criação de relações de poder que devem ser devidamente endereçadas pelos princípios de justiça para se se respeitar a própria inviolabilidade individual fundada na justiça.

Foi a partir desta percepção da importância das instituições informais na construção das desigualdades e não-liberdades e de tudo aquilo que não se reduz ao poder estatal - que buscamos nas feministas e em Gerald Cohen - que reelaboramos a 
interpretação do conceito rawlsiano de "estrutura básica como objeto da justiça" de uma perspectiva feminista e cosmopolita que funde os horizontes de justificação dos âmbitos pessoal, local, social e cosmopolita em um monismo moral que subordina todas as relações efetivas e potenciais entre as pessoas morais ao axioma da igualdade moral humana, em busca de um "direito de saída pleno" para as mulheres. Pleno porque visa permitir a saída nos âmbitos local, social e cosmopolita, de modo a fazer com que todas as instâncias e instituições parte da estrutura básica funcionem como associações, isto é, como instituições de pertencimento voluntário.

Como este direito de saída pleno deve ser tolerante e justo do ponto de vista liberal, deve respeitar o pluralismo moral razoável e o igual direito e liberdade de todos seguirem sua própria concepção de bem, inclusive mulheres que optem pela modéstia. Por isso todo feminismo internacionalista deve ser liberal e por isso a igualdade cosmopolita pode ser apenas uma liberdade instituída por um equalisandum capaz de passar pelo teste de justificação pública, como deveria ser uma lista de bens primários cosmopolitas cujo meio de distribuição justa seriam instituições formais estatais que incidem tolerante e adequadamente sobre o pessoal, o local, o social e o cosmopolita, de modo a implementar o axioma da igualdade humana fundamental em todas as esferas da vida contempladas em nossa interpretação expandida da estrutura básica - endereçandose adequadamente à dicotomia entre público e privado e à dicotomia entre universal e particular de forma a respeitar o pluralismo moral razoável que seja caro para as mulheres do mundo. 


\section{Referências Bibliográficas}

AMNESTY INTERNATIONAL. Women, Violence and Health. Londres, Amnesty International, 2005.

BARRY, Brian. Why Social Justice Matters. Malden-MA, Polity Press, 2008.

BIELEFELDT, Heiner. “'Western' versus 'Islamic' Human Rights Conceptions?: A critique of cultural essentialism in the discussion on human rights". Political Theory, Vol. 28, No. 1, fev. de 2000, pp. 90-121.

BOURDIEU, Pierre. A Dominação Masculina. Trad. Maria Helena Kühner. Rio de Janeiro, Bertrand Brasil, 2011, 10a. ed..

BRIGHOUSE, Harry \& Ingrid Robeyns (orgs.). Measuring Justice. Primary goods and Capabilities. Cambridge, Cambridge University Press, 2010.

BROWN, Cris. "Theories of International Justice”. British Journal of Political Science, Vol. 27, No. 2, 1997, pp. 103-127.

BROWN, Garrett Wallace \& David Held (eds.). The Cosmopolitan Reader. Polity, 2010.

CAVALLAR, Georg. "A sistemática da parte jusfilosófica do projeto kantiano À Paz Perpétua". In Rohden, Valério (org.). Kant e a instituição da Paz. Trad. Peter Naumann. Porto Alegre, ed. universidade/UFRGS, Goethe-Intitut/ICBA, 1997, pp. 7895.

COHEN, G. A. "Incentives, Inequality, and Community", Tanner Lectures on Human Values, $1992 . \quad$ Disponível em http://tannerlectures.utah.edu/lectures/documents/cohen92.pdf. . "Where the Action Is: on the site of distributive justice". Philosophy and Public Affairs, Vol. 26, No. 1, 1997, pp. 3-30. 
. If You're an Egalitarian, How Come You're So Rich? Cambridge-Mass.: Harvard University Press, 2001.

COHEN, Joshua, Matthew Howard \& Martha Nussbaum (orgs.). Is Multiculturalism Bad for Women? Susan Moller Okin with respondents. Princeton, Princeton University Press, 1999.

. "Taking People As They Are?" Philosophy and Public Affairs, Vol. 30, No. 4, 2001, pp. 363-386.

DURHAM, Eunice. "Família e Reprodução Humana". Perspectivas Antropológicas da Mulher 3. Rio de Janeiro, Zahar Editores, 1983, pp. 13-44.

DWORKIN, Ronald. “Objectivity and Truth: You'd Better believe It”. Philosophy and Public Affairs, Vol. 24, No. 2. 1996, pp. 87-139.

ENGLE, Karen. "From Skepticism to Embrace: Human Rights and the American Anthropological Association from 1947-1999”. Human Rights Quarterly, Vol. 23, 2001, pp. 436-559.

ELSTER, Jon. "Local Justice. How institutions allocate scarce goods and necessary burdens." European Economic Review 35, 1991, pp. 273-291.

ESTLUND, David \& Martha Nussbaum (orgs.). Sex, Preference, and Family. Essays on law and nature. Oxford, Oxford University Press, 1997.

FERNEA, Elizabeth Warnock \& Basima Qattan Bezirgan (orgs.). Middle Eastern Muslim Women Speak. Austin, university of Texas Press, 1977.

FREEMAN, Samuel (ed.). The Cambridge Companion to Rawls. Cambridge, Cambridge University Press, 2002, pp. 62-85.

FIERLBECK, Katherine. "The Ambivalent Potential of Cultural Identity". Canadian Journal of Political Science, Vol. 29, No. 1, 1996, pp. 3-22.

GALEOTTI, Anna Elisabetta. "Citizenship and Equality: the place for toleration". Political Theory, Vol. 21, No. 4, pp. 585-605, 1993. 
GUTMANN, Amy. "The Challenge of Multiculturalism in Political Ethics". Philosophy and Public Affairs, Vol. 22, No. 3, 1993, pp. 171-206.

HIRSCHMAN, Albert. Saída, Voz e Lealdade. Reações ao declínio de firmas, organizações e estados. São Paulo, Perspectiva, 1973.

KANT. À Paz Perpétua e outros Opúsculos. Trad. Artur Mourão. Lisboa, Edições 70, 1995.

MacKINNON, Catharine A. Feminism Unmodified. Discourses on Life and Law. Cambridge-Mass., Harvard University Press, 1987.

_ Toward a Feminist Theory of State. Cambridge-Mass., Harvard University Press, 1989.

McCLAIN, Linda. "Negotiating Gender and (Free and Equal) Citizenship: the place of associations". In Fordham Law Review. Symposium Rawls and the Law. Vol. LXXII, Number 5, April 2004, pp. 1569-1598.

MICHELMAN, Frank. "Conceptions of Democracy in American Constitutional Argument: The Case of Pornography Regulation." Tennessee Law Review Vol. 56 (1988-1989), pp. 291-320.

MILLER, David. “Against Global Egalitarianism”. The Journal of Ethics Vol. 9, no. 1/2, "Current Debates in Global Justice", 2005, pp. 55-79.

MURPHY, Liam. "Institutions and the Demands of Justice". Philosophy \& Public Affairs 27, 1998, pp. 251-291.

NAGEL, Thomas. "The Problem of Global Justice". In BROWN, Garrett Wallace \& David Held (eds.). The Cosmopolitan Reader. Polity, 2010, pp. 393-412.

. “The Problem of Global Justice". Philosophy \& Public Affairs 33, no. 2, 2005, pp. 113-147.

. "Rawls and Liberalism". In FREEMAN, Samuel (ed.). The Cambridge Companion to Rawls. Cambridge, Cambridge University Press, 2002, pp. 62-85. 
NUSSBAUM, Martha. Frontiers of Justice. Disability, nationality, species membership. Cambridge-Mass, The Belknap Press of Harvard University Press, 2006.

. "Women and the Law of Peoples." Politics, Philosophy \& Economics 1(3), 2002, pp. 283-306.

Women and Human Development. The capabilities approach. Cambridge, Cambridge University Press, 2001.

Sex and Social Justice. Oxford, Oxford University Press, 2000.

OKIN, Susan Moller. “Gênero, o público e o privado.” Estudos Feministas 16(2), maioagosto de 2008, pp. 305-332.

. "Justice and Gender: An unfinished debate." Fordham Law Review. Symposium Rawls and the Law. Vol. LXXII, Number 5, April 2004, 1537-1567.

. "Is Multiculturalism Bad for Women?" In Cohen, Howard \& Nussbaum (orgs.). Is Multiculturalism Bad for Women? Susan Moller Okin with respondents. Princeton, Princeton University Press, 1999, pp. 7-24.

. "Sexual Orientation and gender: Dichotomizing Differences". In ESTLUND, David \& Martha Nussbaum (orgs.). Sex, Preference, and Family. Essays on law and nature. Oxford, Oxford University Press, 1997.

. Justice, Gender, and the Family. Nova York: Basic Books, 1989.

OLDENBURG, Veena Talwar. Dowry Murder. The imperial origins of a cultural crime. Oxford, Oxford University Press, 2002.

O’NEILL, Onora. “Constructivism in Rawls and Kant”. In FREEMAN, Samuel (org.). The Cambridge Companion to Rawls. Cambridge: Cambridge University Press, 2003, pp. 347-367.

. Bounds of Justice. Cambridge: Cambridge University Press, 2000.

. "Ethical Reasoning and Ideological Pluralism". Ethics, Vol. 98, No. 4, 1988, pp. 705-722. 
POGGE, Thomas. “A Critique of the Capability Approach”. In BRIGHOUSE, Harry \& Ingrid Robeyns (orgs.). Measuring Justice. Primary goods and Capabilities. Cambridge, Cambridge University Press, 2010, pp. 17-60.

_. "Can the Capability Approach Be Justified?" Disponível em http://philosophyfaculty.ucsd.edu/faculty/rarneson/courses/pogge1capability.pdf, acessado em janeiro de 2011.

. “How Should Human Rights Be Conceived?" In Patrick Hayden (ed.). The Philosophy of Human Rights. St. Paul, Paragon House, 2001, pp. 187-211.

. “Rawls on International Justice.” The Philosophical Quarterly 51, Abril 2001. . “Global Justice.” Oxford, Blackwell, 2001.

. “An Egalitarian Law of Peoples." Philosophical and Public Affairs, vol. 23, no. 3, vol. 3, Summer/1994, pp. 195-224.

. Realizing Rawls. Ithaca and London, Cornell University Press, 1989.

PREIS, Ann-Belinda. "Human Rights as Cultural Practice: An Anthropological Critique". Human Rights Quarterly, Vol. 18, No. 2, 1996. Acessado em: http://muse.jhu.edu/journals/human_rights_quarterly/v018/18.2preis.html.

RAWLS, John. "The Basic Structure as Subject”. American Philosophical Quarterly, Vol. 14, No. 2 (1977), pp. 159-165.

. O Liberalismo Político. São Paulo, Martins Fontes, 2001.

Uma Teoria da Justiça. São Paulo, Martins Fontes, 2008.

. Justiça como Equidade. Uma Reformulação. São Paulo: Martins Fontes, 2003.

. The Law of Peoples. With "The idea of public reason revisited". Cambridge-

Mass., Harvard University Press, 2002

O Direito dos Povos. São Paulo, Martins Fontes, 2001. 
O Liberalismo Político. São Paulo: Ática, 2000.

Uma Teoria da Justiça. Lisboa: Presença, 1993.

RORTY, Amelie. "The Hidden Politics of Cultural Identification". Political Theory, Vol. 22, No. 1, 1994, pp. 152-166.

RUSSEL and CAPUTTI. Femicide: The Politics of Women Killing. New York, Twayne Publisher, 1992.

SANDEL, Michael. Liberalism and the Limits of Justice. Cambridge: Cambridge University Press, 2008, 11a. ed. (equivalente à 2a. ed.).

SCANLON, Thomas. The Difficult of Tolerance. Essays in political philosophy. Cambridge, Cambridge University Press, 2006.

SCHEFFLER, Samuel. "Is the Basic Structure Basic?" In SPYNOWICH (org.). The Egalitarian Conscience: Essays in honour of. G. A. Cohen. Oxford, Oxford University Press, 2006, pp. 102-129.

SCOTT, Joan Wallach. The Politics of Veil. Princeton, Princeton University Press, 2007.

. "O Enigma da Igualdade". Estudos Feministas, Vol. 13, No. 1, jan./abril de 2005, pp. 11-30.

_ . "Gender: A useful category of historical analysis". The American Historical Review, Vol. 91, No. 5, 1986, pp. 1053-1075.

SEN, Amartya. Desenvolvimento como Liberdade. São Paulo: Companhia das Letras, 2001.

. "Gender Inequality and Theories of Justice". In NUSSBAUM, Martha \& Jonathan Glover (eds.). Women, Culture and Development. A study of human capabilities. Oxford, Clarendon Press, 1995, pp. 259-273.

SUNSTEIN, Cass. Free Markets and Social Justice. Oxford, Oxford University Press, 1997. 
TAN, Kok-Chor. Justice without Borders. Cosmopolitanism, nationalism and patriotism. Cambridge, Cambridge University Press, 2004.

VILlA, Rafael. Da Crise do Realismo à Segurança Global Multidimensional. São Paulo, Annablume/FAPESP, 1999.

VITA, Álvaro de. O Liberalismo Igualitário. Sociedade democrática e justiça internacional. São Paulo: Martins Fontes, 2008.

A Justiça Igualitária e Seus Críticos. São Paulo: Ed. UNESP, 2000.

Justiça Liberal. Argumentos liberais contra o neo-liberalismo. Rio de Janeiro, Paz e Terra, 1993.

WALZER, Michael. Thick and Thin. Moral argument at home and abroad. Notre Dame: University of Notre Dame Press, 2006.

. On Toleration. New Haven: Yale University Press, 1997.

- Interpretation and Social Criticism. Cambridge-Mass.: Harvard University Press, 1993a.

. "Objectivity and Social Meaning”. In SEN, Amartya \& Martha Nussbaum (org.). The Quality of Life. Oxford: Clarendon Press, 1993b.

WEDEEN, Lisa. "Conceptualizing Culture: possibilities for Political Science." American Political Science Review, Vol. 96, No. 4, dezembro de 2002, pp. 713-728.

WHO. WHO Multi-country Study on Women's Health and Domestic Violence against Women. Geneve, WHO, 2005.

World Report on Violence and Health. Geneve, WHO, 2002.

WIKAN, Unni. Em Honra de Fadime. Assassinato e humilhação. Trad. Beth Honorato. São Paulo, Editora UNIFESP, 2010.

WILLIAMS, Andrew. "Incentives, Inequality, and Publicity." Philosophy and Public Affairs, Vol. 27, No. 3, 1998, pp. 225-47. 